\title{
A Comprehensive Review on 2D and 3D Models of Vertical Ground Heat
}

\section{Exchangers}

\author{
Yuanlong Cui, Jie Zhu*, Ssennoga Twaha, Saffa Riffat \\ Department of Architecture and Built Environment
}

The University of Nottingham, University Park, Nottingham NG7 2RD, United Kingdom

\section{Contents}

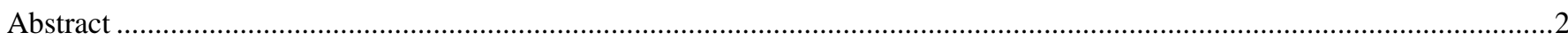

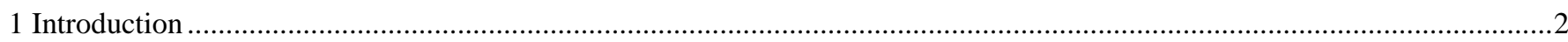

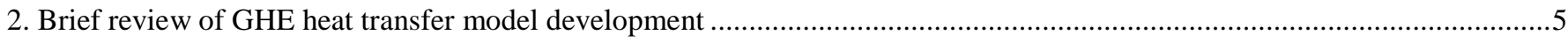

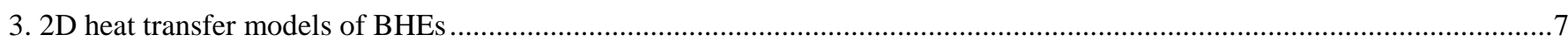

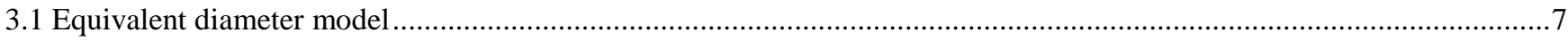

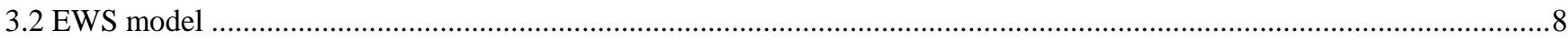

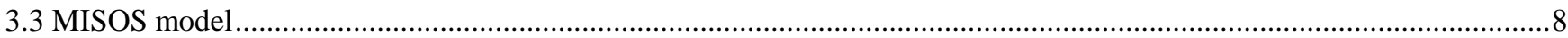

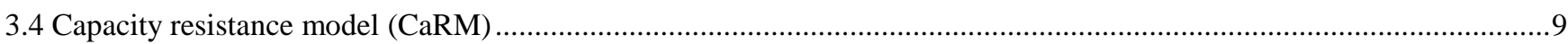

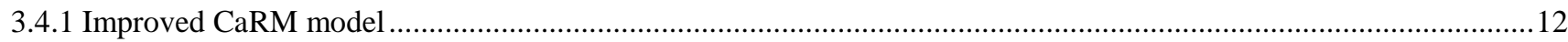

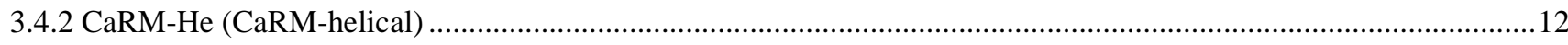

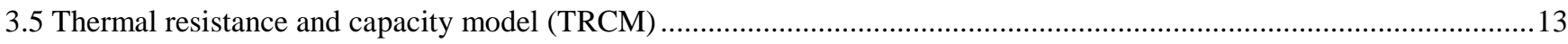

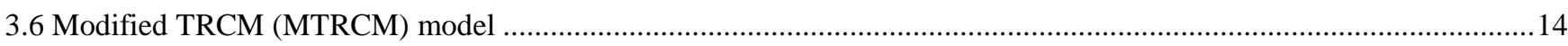

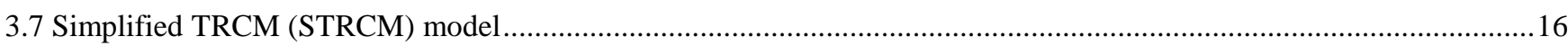

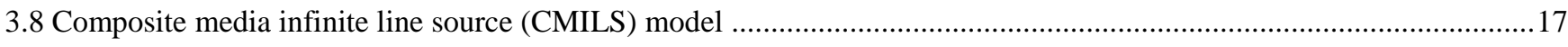

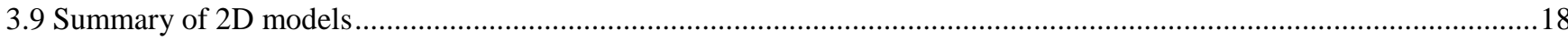

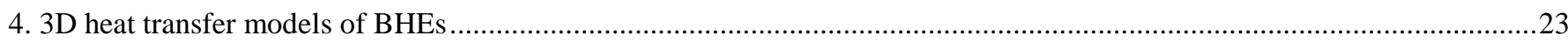

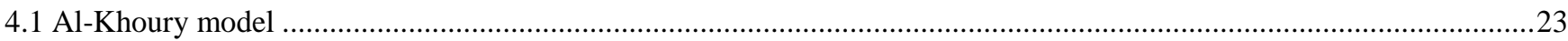

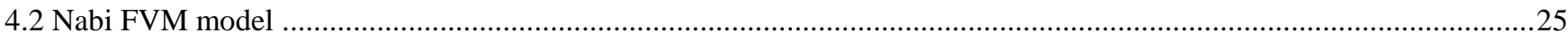

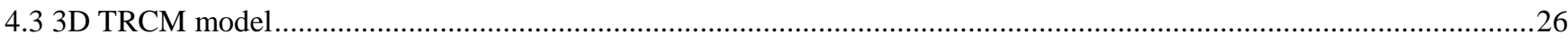

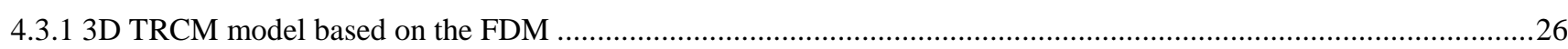

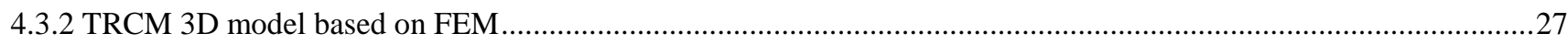

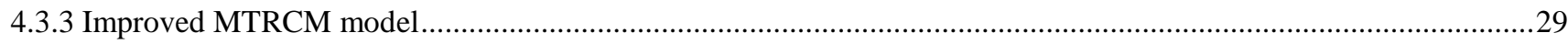

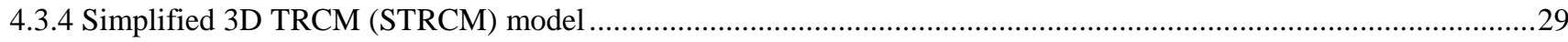

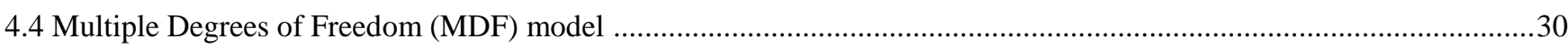

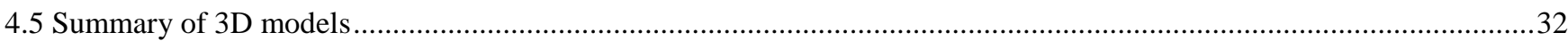

* Corresponding author. Tel: +44-115-8466141 Fax: +44-115-951315

E-mail address: jie.zhu@ nottingham.ac.uk 
5. Further developments and EP foundation models

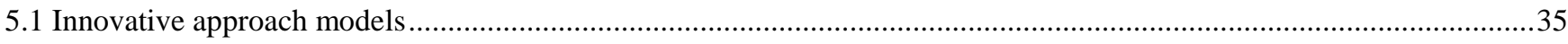

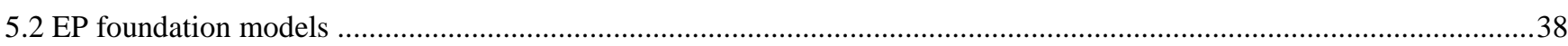

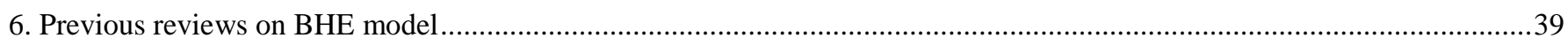

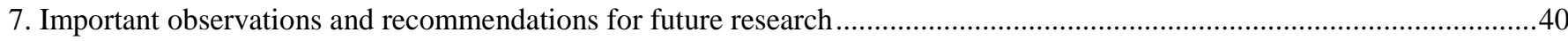

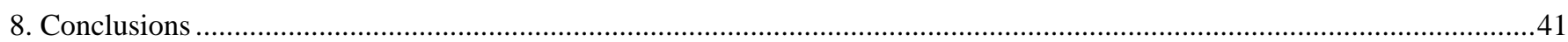

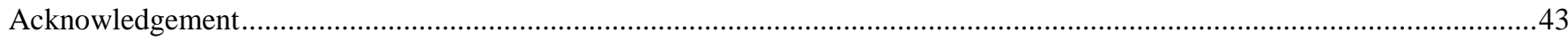

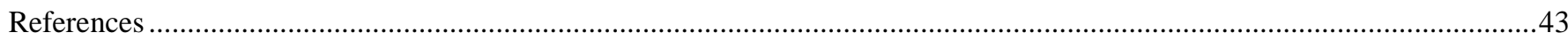

\begin{abstract}
The ground source heat pumps (GSHPs) have been extensively applied to commercial and residential buildings owing to their high-energy efficiencies and low running costs. The key component of the GSHP is a ground heat exchanger (GHE). The stateof-the-art two-dimensional (2D) and three-dimensional (3D) heat transfer models for borehole heat exchanger (BHE) and energy pile (EP) systems are reviewed in this paper. The physical procedures of heat transfer and the derivation of energy conservation within different channels of BHE (e.g., U-, W-, helical-shaped or coaxial-shaped) are summarized, in addition to the primary merits and demerits of each model. The main influencing factors on 2D and 3D model solutions including axial heat transfer, friction heat, spacing shack, thermal resistance, thermal short-circuiting between the inlet-pipe and outlet-pipe, are analysed and compared. Furthermore, various applications of these 2D and 3D models are elaborated. Finally, the recommendations, standpoints and potential future research on BHE heat transfer model are highlighted. It is believed that the work presented will contribute to the record of information and experiences necessary to develop BHEs for GSHP systems.
\end{abstract}

Keywords: 2D and 3D models, BHEs, EPs, Analytical and numerical approaches, Borehole thermal resistances

\title{
1 Introduction
}

Air pollution, global warming and energy shortage have been great challenges since the last century. The carbon dioxide $\left(\mathrm{CO}_{2}\right)$ emission from fossil fuel is widely known as the largest contributor to global warming [1]. To ensure energy conservation, more attention has been paid on reducing $\mathrm{CO}_{2}$ emissions through numerous ways [2-4]. The transformation from fossil fuel to sustainable energy sources has focused mostly on wind [5], solar [6], biomass [7], hydropower as well as geothermal energy [8, 9]. In this context, the ground source heat pump (GSHP) has already become a prevalent option for heating, cooling and hot water source in residential and commercial buildings because of its high-energy efficiency which renders it to be applicable in many countries [10-16], with the annual increase of approximately 10 30\% in 30 countries over the previous decade [12]. In general, GSHPs can be divided into two categories: closed-loop system which is based on the coupling with borehole heat 
exchangers (BHEs) and open-loop system that utilizes groundwater or surface water directly [17, 18]. Different kinds of BHEs, for example horizontal and vertical loops, are used in the modern techniques [19-23]. The main merit of the GSHP systems over the traditional air-conditioning $(\mathrm{A} / \mathrm{C})$ systems is that they have higher Coefficients of Performance (COPs). This is because the soil region can be utilized as a heat source in heating season or as a heat sink in cooling season [24-26]. However, there are two main factors that hinder the popularity of GSHP application: land availability and initial cost. The land availability is the first issue which should be considered. The cost of installing a deep BHE and the risk of the system failure are high. Normally, the payback period varies in the range of 5 to 10 years, making it the key barrier for their exploration and dissemination in the current market [25]. It is reported that the GSHP systems provide the largest amount of applied and installed energy resources, accounting for about $55.30 \%$ of the annual energy utilization and about $70.95 \%$ of the global installed capacity respectively. A huge amount of GSHP installations took place in Europe, China and North America, increasing from 26 in 2000, to 33 in 2005 , to 43 in 2010 , and to 48 in 2015 [25]. Fig.1 presents the annual energy application and installed capacity during the last period of 20 years.

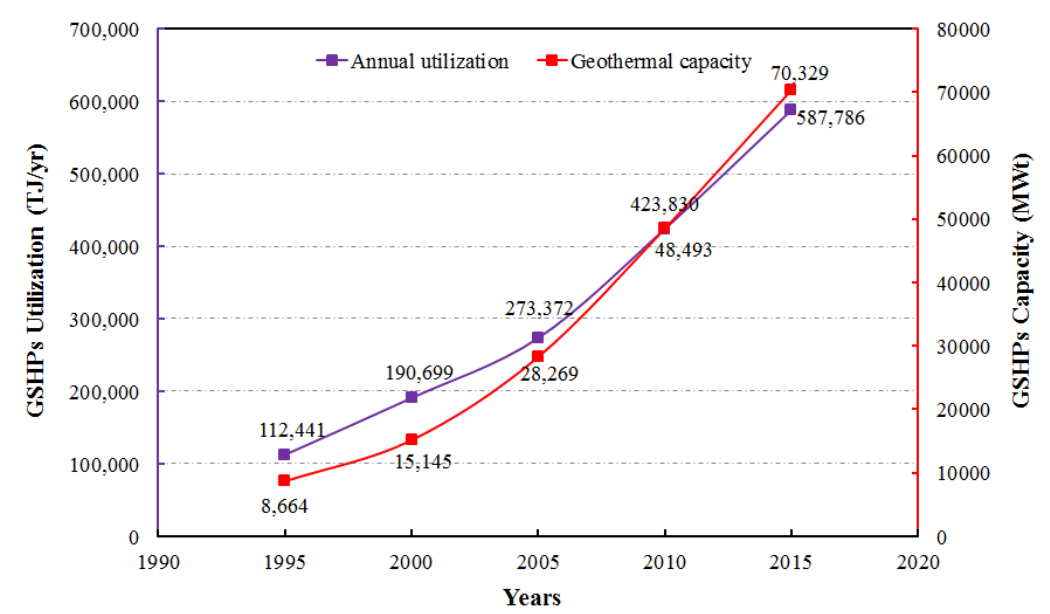

Fig. 1. The annual energy application and installed capacity of GSHP system between 1995 and 2015 [25].

The first known idea of utilizing the soil as a heat source for a heat pump system is presented in a Swiss patent issued in 1912 [26]. Interestingly, the first successful demonstration of a GSHP system is traced back to 1946 in the USA [27]. At that time, Ingersoll and Plass [28] developed a fundamental analytical model for heat conduction within the GSHP system, which served as a basis for some later GSHP designs. The next period of intense activity on GSHP development occurred in 1970s after the first oil crisis. For this period, the primary focus was to develop the vertical BHE because of its minimal land area needed for system installation. Twenty years after that, the BHE heat transfer theoretical models and installation standards were formulated [10, 29-31]. In recent years, a relatively novel technology, known as energy pile (EP) which combines the pile foundation with heat exchanger to fulfil the building load requirements, has been developed [32]. In the EP system, the BHEs are embedded into a cast-in-place concrete pile with a steel frame [13, 33-39]. 


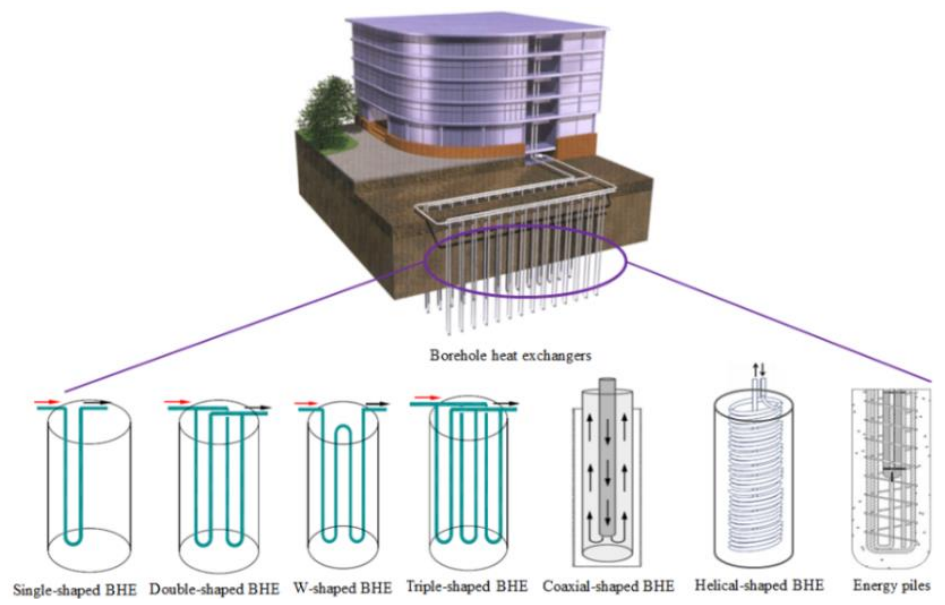

Fig.2. The diagram of BHEs and EP investigated [32, 42, 43].

Normally, BHEs are made of high density polyethylene pipes with around $30 \mathrm{~mm}$ diameter and a borehole with $150 \mathrm{~mm}$ diameter [40]. Various configurations involving single-, double-, triple U-tube [41], W-shaped tube [32], coaxial tube [42] and helicalshaped tube [43] are shown in Fig.2. Some review studies about the BHEs have been done, but the majority concentrate on applications and system related work for example heat pump technologies [44], categories of BHEs and GSHP systems [45], integrated solutions [46], comparison of heating sources [47], in addition to the status of BHE applications in different regions and countries [48-50]. There are many approaches are utilized to analyse the heat transfer performance of the vertical BHE as reported in previous researches [51-61], in which it is indicated that the development of the BHE heat transfer models involving three stages. The first stage from the 1940's to 1960's focused on theoretical models. The second stage from the 1970's to 1980's concentrated on analytical models. The last stage targeted on numerical models which started with the advent of computers since the late 1980's [51]. More specifically, the line source model proposed by Ingersoll et al. [52] and the cylinder source model presented by Carslaw et al. [53] are two examples of the fundamental theoretical methods. They provide the rough approximations to the actual heat transfer processes in the BHE systems. Hart and Couvillion [54] proposed the far-field radius to simulate the soil temperature variation. IGSHPA [55] developed a soil thermal resistance model within a single BHE based on the line source approach, where the superposition principle is adopted to determine the effect of thermal interaction between the adjacent BHEs. Kavanaugh [56] improved the cylinder source model to analyse the uneven heat flow rate within a pipe. A g-function model, with a dimensionless temperature response factor, is another solution [57] that illustrates the response of a single BHE to a unit step heat pulse for estimating the long-term performance of GSHP. A duct storage model (DST) is correspondingly defined to predict the total temperature variation based on the spatial superposition method [58]. Meanwhile, the $2 \mathrm{D}$ finite differential equations are applied to determine the BHE heat transfer rate by using the thermal resistance network method [59]. Shonder and Beck [60] analysed the effective ground thermal conductivity by utilizing different soil equations based on the finite difference method (FDM) and the Crank-Nicolson scheme. Lee and Lam [61] developed a 3D implicit FDM 
in a rectangular coordinate system to depict the quasi-steady state heat transfer process within a BHE through an equivalent thermal circuit. Nowadays, the research is not only carried out on the traditional BHEs but also expanded to EP foundation BHEs. To compensate for the shallow depth of the EP, a helical coil type of BHE is widely used as it can increase the heat transfer [33]. Although several recent studies have covered the heat transfer computations like design method, penalty temperature [62], parameter estimation [63-65], traditional approaches and quasi-steady heat transfer [12, 66, 67], a review of the recent development on 2D and 3D models of the vertical BHE and EP systems is necessary. Heat transfer analysis within a BHE system is a big challenge due to the unsteady state and therefore needs to be given more attention.

Currently, there is a research gap in terms of generalising these $2 \mathrm{D}$ and $3 \mathrm{D}$ heat transfer models to facilitate better understanding of the simulation models as well as advancement of engineering applications for the BHE and EP systems. The purpose of this paper is to fill this knowledge gap by providing a review and a systematic summary of 2D and 3D heat transfer mechanisms within the vertical BHEs. This work aims to improve the awareness on various assumptions and methodologies for these models, in addition to their primary merits and demerits. Furthermore, the recommendations, alternative approaches and some future research works are presented. Meanwhile, the key requirements for solving the issues associated with heat transfer within the BHEs are identified, such as groundwater movement, thermal interaction among multiple BHEs, dynamic ground surface boundary condition, soil property as well as the long-term and short-term influencing factors. Finally, the summaries of the 2D and 3D models are provided to help in selecting a proper model for designing the ground heat exchangers (GHEs) as well as predicting their energy performances. This paper is organized as follows: a brief background regarding the model development is introduced in Section 2 whereas the 2D models of the BHEs are described in Section 3. The 3D models of the BHEs are presented in Section 4 while further developments and EP foundation models are deliberated in Section 5. The previous reviews on the GHE heat transfer models are given in Section 6 whereas the challenges facing the BHE and the recommendations for future research are provided in Section 7. Finally, some critical conclusions are summarized in Section 8.

\section{Brief review of GHE heat transfer model development}

Several studies categorise the BHE models into three types: analytical, numerical and hybrid of analytical and numerical models. The classical analytical models normally depend on Kelvin's line source theory [68] and the cylinder source model [69]. The temperature response expression of a specific time at any radius is expressed as the infinite line source model by Ingersoll and Plass [70]. Zeng et al. [71] developed an analytical formulation by using the point source method to determine the soil temperature variation based on the finite line source theory. In addition, there are other modified models developed from Kelvin's line source method such as Hart and Couvillion's approach [72] as well as Bose's method [73]. The cylinder source theory was first proposed by Carslaw and Jaeger [69], then modified by Ingersoll et al. [74]. The modified cylinder source theory has been upgraded by Kavanaugh [75, 76], Deerman [77], Yavuzutrk [78, 79], Bernier [80] and Young [81]. It is noted that the effects of 
axial heat flow along the BHE depth, the heat flux across the soil surface and BHE bottom are not considered in both Kelvin's line source and the cylindrical source models, thereby limiting the long-term operation analysis of the GHE systems. Bernier et al. [80] studied a multiple load aggregation algorithm to estimate the performance of a single BHE at a variable load through the cylindrical source method. Lamarche and Beauchamp [82] developed a novel analytical solution and obtained very similar results to those given by Eskilson [83]. Yang et al. [84] described an analytical approach which divides the BHE region into two sections with the purpose of analysing the heat transfer mechanism of a single vertical BHE applied to the GSHP system. Various numerical and hybrid analytical/numerical solutions have been applied to the BHEs system simulation. Eskilson [66] determined the soil temperature variation within the finite length of a single BHE using the two-dimensional explicit FDM. In this model, the soil surface temperature is assumed to be a constant value whereas the thermal capacities of the filling material and pipe wall are ignored. Meanwhile, the dimensionless parameters referred to as the g-functions, are proposed to depict the thermal behaviour of a BHE, whereby the developed g-function curves depend on each BHE field configuration. To clarify the BHE temperature variation with time, Yavuzturk [85] improved the Eskilson's model by considering the effect of the working fluid and the grout thermal capacities, such that the g-functions could be applied to calculate the temperature variation during the short-term operation period. Hellström $[58,86]$ illustrated a duct storage model (DST) to estimate the performance of a BHE based on the steady-state heat flux. Alternatively, Kavanaugh [56] studied the behaviour of a BHE with a concentric tube based on the FDM whereas Rottmayer et al. [87, 88] evaluated the performance of a single BHE by the FDM and discretized both the internal components of the BHE and its nearby soil within the cylindrical coordinate system. Likewise, Gehlin and Hellstrom [89] analysed the effect of groundwater movement on the thermal response within an infinite BHE using the FDM with regular square meshes. Chiasson et al. [90] researched the influence of groundwater flow on the heat transfer rate based on a 2D finite element method (FEM) by discretizing a 4×4 BHE model. He et al. [91, 92] proposed a 3D numerical heat transfer model for a BHE by using the finite volume method (FVM) known as the General Elliptical Multi-Block Solver (GEMS3D). This method is used to analyse the transient heat transfer in and around a BHE. Marcotte and Pasquier [93] proposed a "p-linear" mean temperature depended on a 3D numerical heat transfer model to calculate the BHE thermal resistance through the thermal response tests. Koohi-Fayegh and Rosen [94] developed a semi-analytical method to estimate the performance of a GHE with respect to "thermal pollution" within the ground nearby the BHE. Moreover, Bandyopadhyay et al. [95] studied a semi-analytical model for the short time unsteady state response of a BHE with a constant rate of heat production.

Analytical expressions for heat transfer models are desirable to investigate engineering issues although at times, they are usually complicated for widespread applications in some design procedures. For this reason, in the last few years, numerical methods of heat transfer model and system design have widely spread through the utilization of modern computers. The FDM seems to play a critical role in this field, because it is typically applied to figure out the heat transfer issues $[87-89,91,96-98]$. In contrast, the 
FEM has gained momentum and was first applied by Muraya [98], followed by AL-Khoury et al. [40, 99-101], Marcotte and Pasquier [102] as well as Raymond et al. [103, 104]. Moreover, the FVM has also been employed to analyse the heat transfer process within the BHE. One of the earlier studies in this field is given by Yavuzturk [78, 79]. Later, Rees et al. [105, 106] proposed an axial-symmetric BHE model by considering the effect of groundwater flow. This model was refined later by He et al. [91, 92] to estimate the behaviour of the GSHP system. The following sections 3 and 4 mainly present a detailed review of 2D and 3D BHE models. The discussion is based on the methods that are frequently used, on top of the models proposed more recently.

\section{2D heat transfer models of BHEs}

Nowadays, models are still a significant field for research and application. They have been treated as important instruments for the long-term performance measurement, system optimisation and ground thermal conductivity calculation. Heat transfer procedure within a BHE includes many uncertain features, for instance, soil thermal physical properties, groundwater movement and building heating and cooling loads over a long lifespan of several or tens of years [12]. For this reason, the BHE heat transfer procedure is quite complicated and usually separated into two sections. One section is the soil region, while another section is the BHE region, involving the filling material, U-tube pipes and the working fluid within the pipe. Presently, several popular 2D models are available to help in heat transfer calculation within the vertical BHE by applying various methods including the equivalent diameter method [107, 108], EWS model [109], MISOS model [110], capacity resistance model (CaRM) [111], thermal resistance and capacity models (TRCM) [112], in addition to the composite medium infinite line source (CMILS) model $[77,113,114]$. These 2D models are described in detail in the following section.

\subsection{Equivalent diameter model}

$\mathrm{Gu}$ and O’Neal [115] proposed an equivalent diameter method as the analytical expression for investigating the steady-state vertical BHE thermal resistances. Fig. 3 presents the transform process based on the assumption that one pipe is concentric within an infinite composite region. This approach is depicted by an algebraic equation to combine the working fluid within a U-tube into one circular region within the BHE centre.
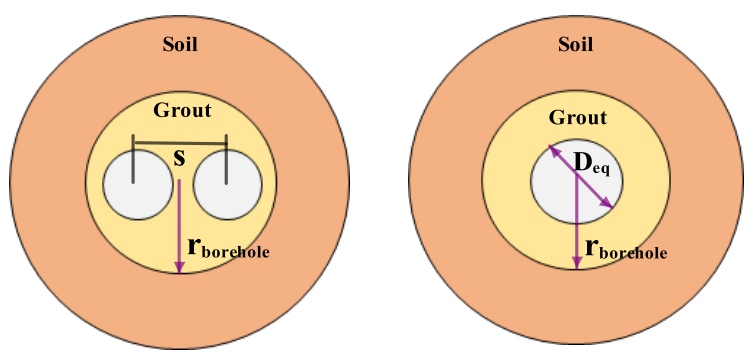

Fig.3. The schematic diagram of the equivalent BHE method [115]. 
The borehole thermal resistance $\left(\mathrm{R}_{\mathrm{b}}\right)$ is calculated based on the shank spacing which is expressed as:

$$
\begin{gathered}
\mathrm{R}_{\mathrm{b}}=\frac{\ln \left(\frac{\mathrm{d}_{\mathrm{b}}}{\mathrm{d}_{\mathrm{eq}}}\right)}{2 \pi \mathrm{k}_{\mathrm{g}}} \\
\mathrm{D}_{\text {eq }}=\sqrt{2 \mathrm{~d}_{\mathrm{p}} \cdot \mathrm{s}}, \mathrm{d}_{\mathrm{p}}<\mathrm{s}<\mathrm{R}_{\mathrm{b}}
\end{gathered}
$$

Where, $R_{b}$ is the borehole thermal resistance $(\mathrm{K} \cdot \mathrm{m} / \mathrm{W})$; $\mathrm{kg}_{\mathrm{g}}$ is the grout thermal conductivity $(\mathrm{W} / \mathrm{m} \cdot \mathrm{K})$; $\mathrm{d}_{\mathrm{b}}$ is the BHE diameter $(m) ; d_{e q}$ is the equivalent diameter $(m) ; d_{p}$ is the U-tube diameter $(m) ; s$ is the shank spacing $(m)$.

The popular equivalent-diameter theoretical method is used in many studies [116-124], which assumes the U-tube within a BHE as a pipe of 'equivalent diameter'. This hypothesis plays a role in simplifying the complicated multi-dimensional geometry to a 1D hollow cylindrical model. The simplified problem can be solved through either the Laplace transform approach [116] or the orthogonal expansion approach [118].

\subsection{EWS model}

A FEM model for a double U-tube called EWS is developed by Wetter and Huber [109] based on the TRANSYS simulation environment with Type 451 module. This approach is comparatively simple and precise for the whole heat transfer procedure. In terms of the radial direction, the BHE and its nearby soil layers are divided into equidistance. Meanwhile, in the axial (vertical) direction, the soil layers are also classified as equidistant layers without accounting for the axial heat flow even though each element has its own thermal properties.

For the radial direction, the 1D heat transfer model is expressed based on the Crank-Nicholson algorithm as:

$\frac{\partial \mathrm{T}}{\partial \mathrm{t}}=\frac{\lambda}{\rho \mathrm{c}_{\mathrm{p}}} \frac{\partial^{2} \mathrm{~T}}{\partial \mathrm{x}^{2}}$

Where, $\mathrm{T}$ is the temperature $\left({ }^{\circ} \mathrm{C}\right) ; \rho$ is the density $\left(\mathrm{kg} / \mathrm{m}^{3}\right) ; \mathrm{c}_{\mathrm{p}}$ is the specific heat capacity $\left(\mathrm{J} / \mathrm{kg} \cdot{ }^{\circ} \mathrm{C}\right) ; \mathrm{t}$ is the time $(\mathrm{s}) ; \lambda$ is the thermal conductivity $(\mathrm{W} / \mathrm{m} \cdot \mathrm{K})$.

For the vertical direction, the finite length of a borehole element is expressed as:

$\mathrm{dl}=\frac{\mathrm{Bl}}{\operatorname{DimAxi}}$

Where, $\mathrm{dl}$ is the length of a BHE element; $\mathrm{Bl}$ is the BHE length; DimAxi is the number of grid points in the axial direction.

Generally, this model is suitable for a short-term operation. However, Huber and Pahud [124] improved the model to determine the temperature variations within the working fluid, grout and the soil nearby the BHE.

\subsection{MISOS model}

To enhance the representation accuracy of the BHE geometry in EWS model, a new model called MISOS is proposed by Oppelt et al. [110], which is more concerned with the details of the grout. 


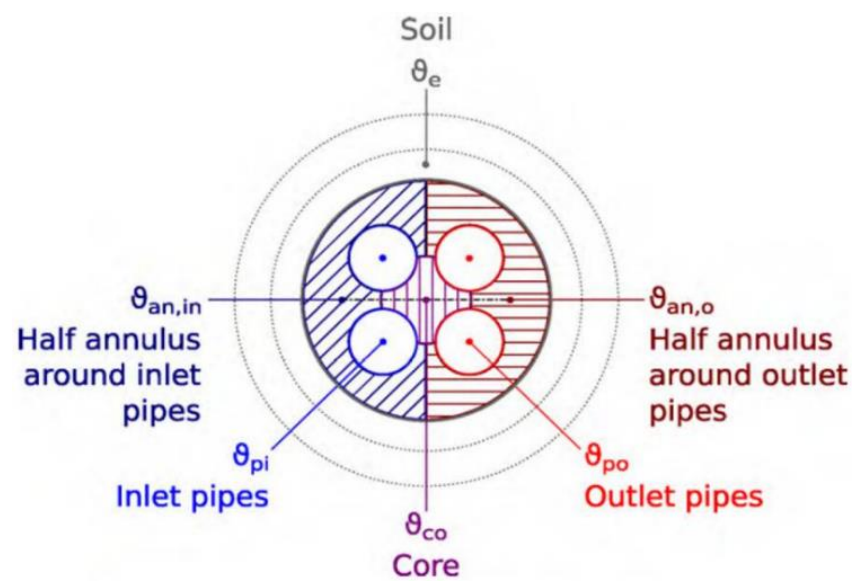

Fig.4. Three regions of a BHE with double U-tube pipes [110].

By comparing MISOS model with EWS model, the grout region is classified into three computational zones, namely, the core region, the half annulus surrounding the inlet pipes and the half annulus surrounding the outlet pipes as shown in Fig.4. The core region is referred to as a detached region as it has the lowest temperature in the heating season. On the other hand, the remaining annular grout region is divided into two parts involving the inlet and outlet pipes. The temperature in each element is obtained based on the energy balance. The MISOS model is capable of simulating the BHE heat transfer with a minimal computer time (0.1s) compared with CFD simulation time (8 hours).

\subsection{Capacity resistance model (CaRM)}

Carli et al. [111] developed a 2D capacity resistance model (CaRM) to analyse the BHE transient heat transfer performance in three different configurations. This method depends on the electrical analogy to deal with the heat transfer issue by using an equivalent electrical circuit of thermal capacities and thermal resistances. Meanwhile, the thermal interference among multiple BHEs and the fluid flow pattern along the inner pipe are also considered. The model is divided into three sections including the soil, BHE and fluid regions. The BHE region is discretized into several layers along its depth and also divided into several slices in the radial direction without considering the BHE thermal capacitance. The advantage of this approach is that its computation time is lower than that of the FVM model. In the soil region, the considered heat transfer is only the heat conduction neglecting the effect of groundwater movement. The BHE and its nearby soil layers are both classified into $\mathrm{m}$ slices in the axial direction as presented in Fig.5 (a). Each slice is further divided into $\mathrm{n}$ annular parts in the radial direction as shown in Fig.5 (b). The schematic of the CaRM model is depicted in Fig.5(c). 


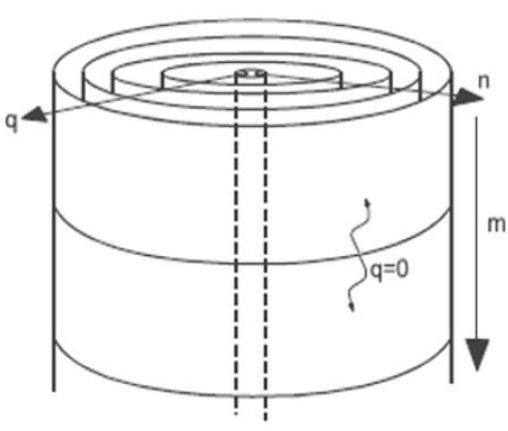

(a)

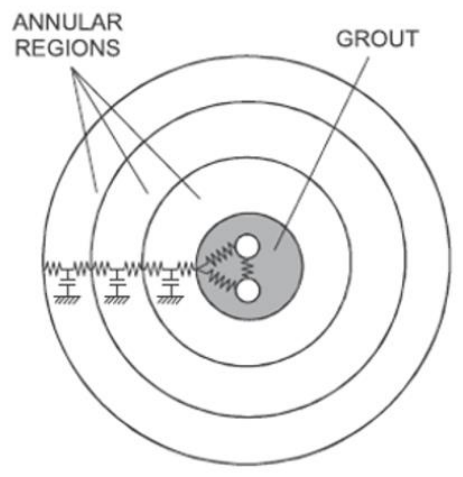

(b)

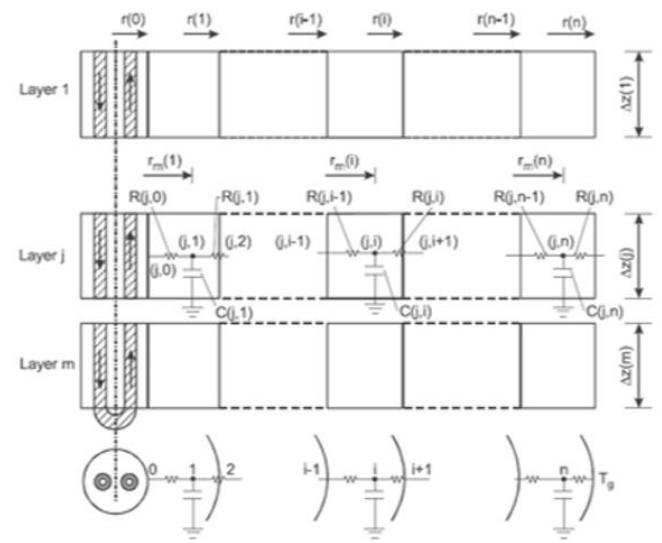

(c)

Fig.5. (a) Soil layers; (b) radial direction; (c) axial direction [111].

In this model, some assumed conditions are given as follows:

The axial direction heat transfer between two overlapped slices is ignored;

The temperature variation is based on the radius and time for any annular region;

A single vertical BHE is regarded as a cylindrical symmetry;

Based on these assumptions, the annular region heat transfer equations can be written as:

$\frac{T(j, i-1)-T(j, i)}{R(j, i-1)}+\frac{T(j, i+1)-T(j, i)}{R(j, i)}=C(j, i) \cdot \frac{\left[T(j, i)-T_{-\Delta \tau}(j, i)\right]}{\Delta \tau}$

Where, $\mathrm{R}$ is the thermal resistance $(\mathrm{K} / \mathrm{W}) ; \mathrm{C}$ is the volume thermal capacity $(\mathrm{J} / \mathrm{kg} \cdot \mathrm{K}) ; \Delta \tau$ is the discretization time step (s); i and $\mathrm{j}$ are the soil discretization indices in the radial and axial directions respectively; $\mathrm{T}$ is the temperature $\left({ }^{\circ} \mathrm{C}\right)$;

The soil heat capacity is expressed as:

$\mathrm{C}(\mathrm{i}, \mathrm{j})=\rho \cdot c \cdot \pi \cdot\left[\mathrm{r}^{2}(\mathrm{i})-\mathrm{r}(\mathrm{i}-1)^{2}\right] \cdot \Delta \mathrm{z}(\mathrm{j})$

Where, $\mathrm{c}$ is the specific heat of the soil layer $(\mathrm{J} / \mathrm{kg} \cdot \mathrm{K}) ; \mathrm{r}(\mathrm{i})$ and $\mathrm{r}(\mathrm{i}-1)$ are the radii $(\mathrm{m}) ; \rho$ is the soil density $\left(\mathrm{kg} / \mathrm{m}^{3}\right) ; \Delta \mathrm{z}$ is the length of the soil control volume in the vertical direction $(\mathrm{m})$.

In the BHE region, heat transfer occurs between the BHE and pipe on the basis of the thermal physical properties of the grout and pipes as well as the position of the pipes. Fig. 6 depicts the schematic of heat transfer mechanisms for the three configurations. Their heat transfer equations are summarized in Table 1. 


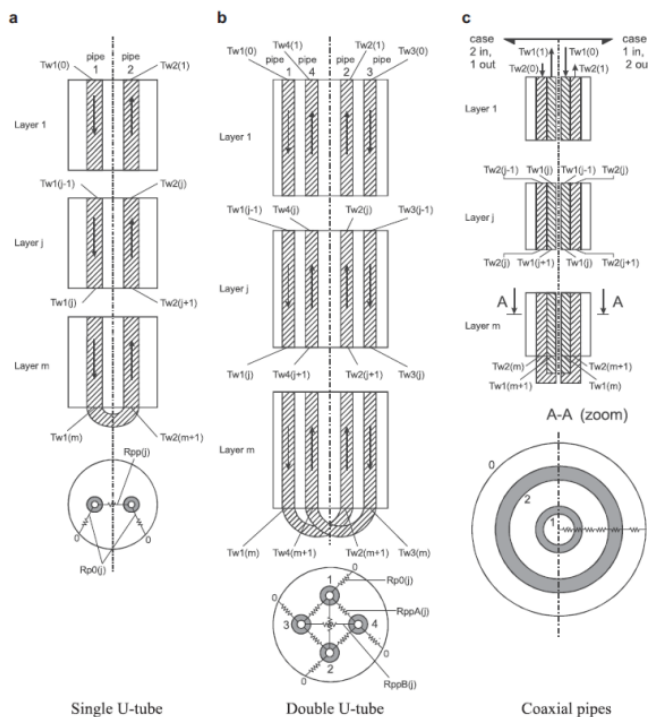

Fig.6. Modelling scheme of the BHE and various kinds of heat exchanger [111].

Table 1 Heat transfer equations for three different kinds of U-tube pipe [111].

\begin{tabular}{|c|c|c|}
\hline & For pipes & For BHE \\
\hline Single U-tube & $\frac{T_{w i}(j)-T_{p, i}(j)}{R_{c o n v}(j)}+\frac{\left|T_{p, i}(j)-T_{p, i}(j)\right|}{R_{p p}(j)}+\frac{T_{o}(j)-T_{p, 1}(j)}{R_{p o}(j)}=0 \quad(i=1,2)$ & $\frac{T(j, 1)-T_{0}(j)}{R(j, 0)}+\frac{T_{p, 1}(j)-T_{0}(j)}{R_{p 0}(j)}+\frac{T_{p, 2}(j)-T_{0}(j)}{R_{p 0}(j)}=0$ \\
\hline Double U-tube & $\begin{array}{l}\frac{T_{w, i}(j)-T_{p, i}(j)}{R_{c o n v}(j)}+\frac{T_{p, i}(j)-T_{p, i}(j)}{R_{p p A}(j)}+\frac{T_{p, i}(j)-T_{p, 1}(j)}{R_{p p B}(j)} \\
\quad+\frac{T_{p, i}(j)-T_{p, i}(j)}{R_{p p A}(j)}+\frac{T_{0}(j)-T_{p, i}(j)}{R_{p 0}(j)}=0 \quad(i=1,2,3,4)\end{array}$ & $\begin{array}{l}\frac{T(j, 1)-T_{0}(j)}{R(j, 0)}+\frac{T_{p, 1}(j)-T_{0}(j)}{R_{p 0}(j)}+\frac{T_{p, 2}(j)-T_{0}(j)}{R_{p o}(j)} \\
+\frac{T_{p, 3}(j)-T_{0}(j)}{R_{p o}(j)}+\frac{T_{p, 4}(j)-T_{0}(j)}{R_{p o}(j)}=0\end{array}$ \\
\hline Coaxial pipe & $\begin{array}{c}\frac{\mathrm{T}_{\mathrm{w}, 1}(\mathrm{j})-\mathrm{T}_{\mathrm{p}, 1}(\mathrm{j})}{2 \cdot \pi \cdot \mathrm{r}_{\mathrm{i}, 1} \cdot \alpha_{\mathrm{p}, 1} \cdot \Delta \mathrm{z}(\mathrm{j})}+\frac{1}{2 \cdot \pi \cdot \Delta \mathrm{z}(\mathrm{j}) \cdot \lambda_{\mathrm{p}, 1}} \cdot \ln \left(\frac{\mathrm{r}_{\mathrm{o}, 1}}{\mathrm{r}_{\mathrm{i}, 1}}\right) \\
+\frac{\mathrm{T}_{\mathrm{w}, 2}(\mathrm{j})-\mathrm{T}_{\mathrm{p}, 1}(\mathrm{j})}{\frac{1}{2 \cdot \pi \cdot \mathrm{r}_{\mathrm{o}, 1} \cdot \alpha_{\mathrm{p}, 2} \cdot \Delta \mathrm{z}(\mathrm{j})}}=0 \text { (pipe 1) } \\
\frac{\mathrm{T}_{\mathrm{w}, 2}(\mathrm{j})-\mathrm{T}_{\mathrm{p}, 2}(\mathrm{j})}{2 \cdot \pi \cdot \mathrm{r}_{\mathrm{i}, 2} \cdot \alpha_{\mathrm{p}, 2} \cdot \Delta \mathrm{z}(\mathrm{j})}+\frac{1}{2 \cdot \pi \cdot \Delta \mathrm{z}(\mathrm{j}) \cdot \lambda_{\mathrm{p}, 2}} \cdot \ln \left(\frac{\mathrm{r}_{\mathrm{o}, 2}}{\mathrm{r}_{\mathrm{i}, 2}}\right) \\
+\frac{\mathrm{T}_{\mathrm{o}}(\mathrm{j})-\mathrm{T}_{\mathrm{p}, 2}(\mathrm{j})}{\frac{1}{2 \cdot \pi \cdot \Delta \mathrm{z}(\mathrm{j}) \cdot \lambda_{\text {grout }}} \cdot \ln \left(\frac{\mathrm{r}_{\mathrm{b}}}{\mathrm{r}_{\mathrm{o}, 2}}\right)}=0(\text { pipe 2) }\end{array}$ & $\frac{T_{p, 2}(j)-T_{o}(j)}{\frac{1}{2 \cdot \pi \cdot \Delta z(j) \cdot \lambda_{\text {grout }}} \cdot \ln \left(\frac{r_{b}}{r_{0,2}}\right)}+\frac{T(j, 1)-T_{o}(j)}{R(j, 0)}=0$ \\
\hline
\end{tabular}

In the fluid region, the thermal energy balance within each pipe for the $\mathrm{j}$-th layer can be expressed as:

$\mathrm{m}_{\mathrm{w}} \cdot \mathrm{c}_{\mathrm{pw}} \cdot\left[\mathrm{T}_{\mathrm{w}, \text { in }}(\mathrm{j})-\mathrm{T}_{\mathrm{w}, \text { out }}(\mathrm{j})\right]=2 \cdot \pi \cdot \mathrm{r}_{\mathrm{i}} \cdot \alpha \cdot \Delta \mathrm{z}(\mathrm{j}) \cdot\left[\mathrm{T}_{\mathrm{w}}(\mathrm{j})-\mathrm{T}_{\mathrm{p}}(\mathrm{j})\right]$

Where, $\mathrm{m}_{\mathrm{w}}$ is the fluid flow rate $(\mathrm{kg} / \mathrm{s}) ; \mathrm{c}_{\mathrm{pw}}$ is the fluid specific heat $(\mathrm{J} / \mathrm{kg} \cdot \mathrm{K}) ; \mathrm{T}_{\mathrm{w} \text {,in }}$ and $\mathrm{T}_{\mathrm{w}, \text { out }}$ are the inlet and outlet temperatures $\left({ }^{\circ} \mathrm{C}\right)$ respectively; $\mathrm{T}_{\mathrm{w}}$ is the average fluid temperature $\left({ }^{\circ} \mathrm{C}\right) ; \mathrm{T}_{\mathrm{p}}$ is the pipe average internal surface temperature $\left({ }^{\circ} \mathrm{C}\right)$; and a is the convective heat transfer coefficient $\left(\mathrm{W} / \mathrm{m}^{2} \cdot \mathrm{K}\right)$.

However, the disadvantage of the CaRM approach is that only a local steady state region for each BHE is considered, ignoring the thermal capacities of the filling materials and working fluid. In addition, this approach cannot be applied to simulate the 
short-term operation. To compensate for these issues, an improvement of the CaRM model has been made by Zarrella et al. [125128] as discussed in the following sections.

\subsubsection{Improved CaRM model}

The CaRM model [125] has been improved due to the following reasons:

The thermal capacities of the BHE and working fluid should be considered;

$>$ The short-term operation is considered and should be investigated, on top of clarifying the soil temperature variation;

$>$ The lateral groundwater movement should be considered;

The thermal fluctuations on the aquifer need to be investigated;

According to Fig.7 (a), the BHE region is classified into two regions: the core and shell regions. As a refined approach, an additional thermal node is applied as presented in Fig.7 (b). In this case, the BHE wall thermal energy balance equations are revised by considering of the shell thermal capacitance. The improved CaRM model is capable of solving the transient heat transfer issue because the BHE thermal capacitances are considered. Moreover, this approach can be used to study the double U-tube system. The results from the improved model illustrate that the thermal capacitance of the working fluid is significant for the short-term analysis. Meanwhile, the comparison of the simulation results from the improved CaRM model with the COMSOL results and the experimental data showed good agreement among them.
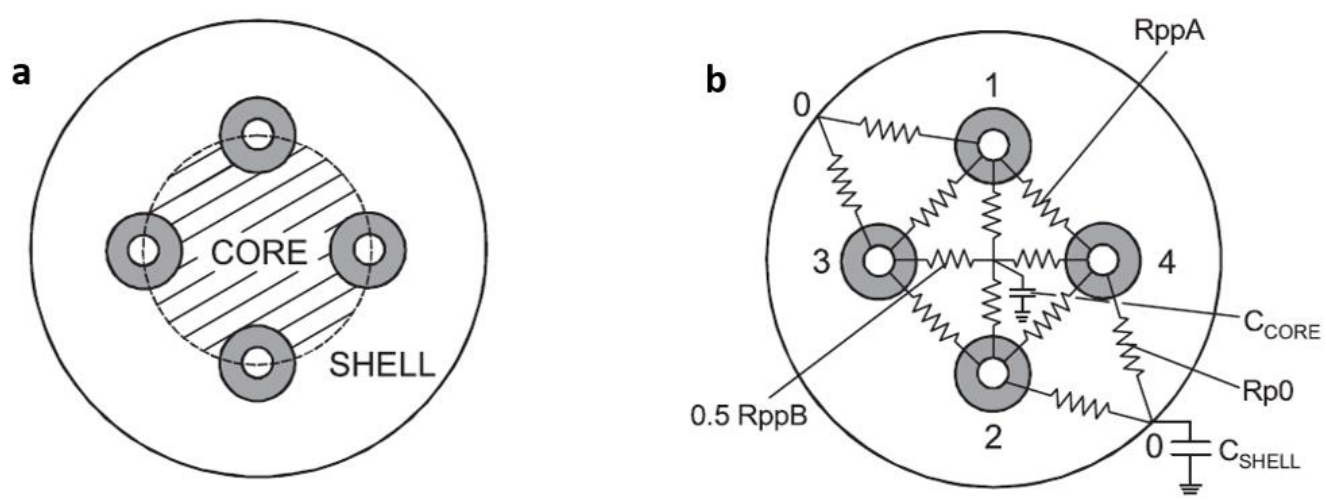

Fig.7. (a) The grout core and shell regions; (b) the grout thermal capacitance [125].

\subsubsection{CaRM-He (CaRM-helical)}

The vertical BHE systems are the most widespread because they require less land area. However, the initial expense of a BHE unit is generally higher than that of the traditional air conditioning unit owing to the costs associated with drilling and installation of the BHE. For this reason, many researchers and system designers attempt to refine the BHE thermal behaviour so that the total BHE length can be decreased. The helical heat exchangers are commonly mounted where the soil temperature is undulated because of the ambient air temperature and solar radiation [139]. To address these issues, Zarrella and De Carli [126] proposed a CaRM-Helical (CaRM-He) approach to analyse the thermal behaviour of the short helical BHE. In comparison with the original model $[111,125]$, only the soil surrounding the BHE is taken into account and the heat transfer occurs only along the axial 
direction. Fig. 8 presents a description of the proposed CaRM-He approach. As observed, the soil is categorised into the surface, BHE and deep parts. For the BHE region, the heat transfer occurs along both the axial and radial directions, whereas the deep and surface parts are regarded as pure heat conduction along the vertical direction.

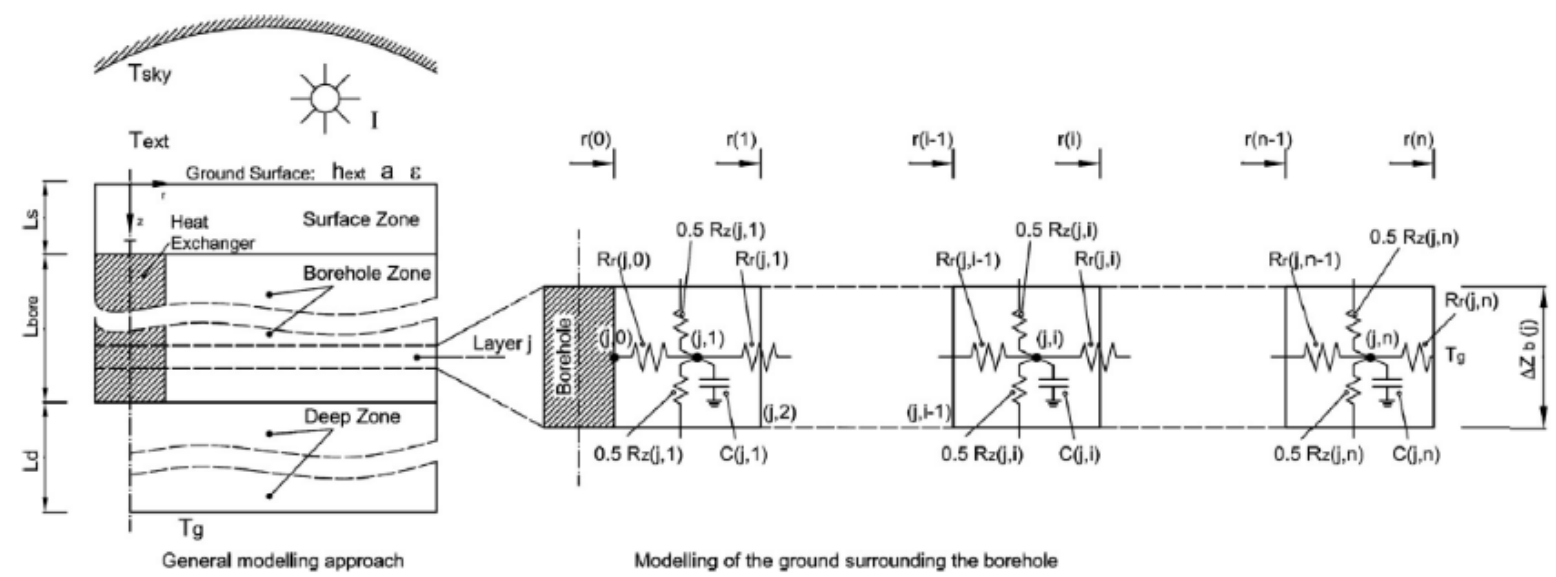

Fig.8. General illustration of the CaRM-He model [126].

The helical heat exchanger test was performed in Erlangen-Nuremberg (Germany), from which the model simulation results were validated by the experimental data with a good agreement. In this model, the pitch between the turns of the helical pipe and the axial heat transfer were investigated by considering the local weather conditions. Subsequently, the new version of CaRMHelical (CaRM-He) [128] has been used to compare the thermal performance between a double U-tube BHE and a helical-shaped pipe at a shallow depth. The interaction between the soil surface and the ambient air is taken into account for both short-term and long-term periods. This comparative analysis indicates that the helical-shaped pipe is affected more by the axial heat transfer than the double U-tube with the same ground thermal diffusivity. Moreover, the helical-shaped pipe allows a better control of the peak load than the double U-tube. This results in a reduced design size of the ground-coupled system in addition to the appropriate running control strategies. Furthermore, a helical heat exchanger has superior thermal performance than the traditional double U-tube with the same BHE length during the long-term operation period. Hence, a shorter BHE can be applied.

\subsection{Thermal resistance and capacity model (TRCM)}

Bauer et al. $[129,130]$ proposed a 2D TRCM for symmetrically positioned single, double and coaxial BHE configurations based on the delta-circuit model. Fig.9 presents the horizontal cross-sections and the corresponding TRCMs for three types of heat exchangers. 

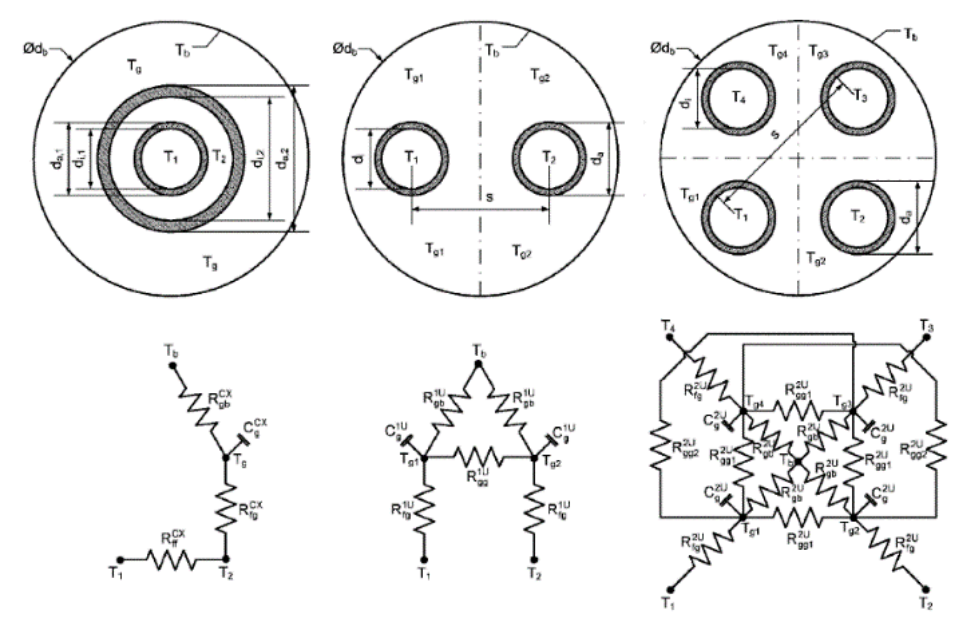

Fig.9. TRCM model for three kinds of BHEs [129].

In all cases, heat transfer occurs between the BHE wall and pipe across the grout region. Specifically, the capacity of the filling material is taken into account with one capacity per tube. However, the BHE is categorized into two sections for a single pipe loop and four parts for the double pipe loop. For the coaxial BHE, the heat transfer from one tube to the other is in one direction. The heat transfer balance equations for the three BHEs are given in Table 2. These results indicate that the TRCM model is more suitable for an unsteady state condition. Furthermore, this model can achieve a much higher precision in the transient condition compared with the model which does not consider the thermal capacity.

Table 2 The TRCM heat transfer balance equations [129-130].

\begin{tabular}{|c|c|c|c|}
\hline & Single U-tube BHE & Double U-tube BHE & Coaxial BHE \\
\hline $\begin{array}{l}\text { The } R_{\mathrm{fg}} \text { occurs between the } \\
\text { working fluid and grout. }\end{array}$ & $\mathrm{R}_{\mathrm{fg}}^{\mathrm{IU}}=\mathrm{R}_{\text {conv }}^{\mathrm{IU}}+\mathrm{R}_{\text {cond, } 1}^{\mathrm{IU}}+\mathrm{R}_{\text {cond,2 }}^{\mathrm{IU}}$ & $\mathrm{R}_{\mathrm{fg}}^{2 \mathrm{U}}=\mathrm{R}_{\text {conv }}^{2 \mathrm{U}}+\mathrm{R}_{\text {cond, } 1}^{2 \mathrm{U}}+\mathrm{R}_{\text {cond }, 2}^{2 \mathrm{U}}$ & $x$ \\
\hline $\begin{array}{l}\text { The } R_{\text {ff }} \text { occurs between the } \\
\text { working fluid and outer } \\
\text { pipe (for coaxial). }\end{array}$ & $x$ & $x$ & $\mathrm{R}_{\mathrm{ff}}^{\mathrm{CX}}=\mathrm{R}_{\text {conv }, 1}^{\mathrm{CX}}+\mathrm{R}_{\text {cond }, 1}^{\mathrm{CX}}+\mathrm{R}_{\text {conv }, 2}^{\mathrm{CX}}$ \\
\hline $\begin{array}{l}\text { The } R_{f g} \text { occurs between the } \\
\text { working fluid and the grout } \\
\text { (for coaxial). }\end{array}$ & $x$ & $x$ & $\mathrm{R}_{\mathrm{fg}}^{\mathrm{CX}}=\mathrm{R}_{\text {conv }, 3}^{\mathrm{CX}}+\mathrm{R}_{\text {cond }, 2}^{\mathrm{CX}}+\mathrm{R}_{\text {cond }, 3}^{\mathrm{CX}}$ \\
\hline $\begin{array}{l}\text { The } \mathrm{R}_{\mathrm{gb}} \text { occurs between the } \\
\text { grout and the BHE wall. }\end{array}$ & $\mathrm{R}_{\mathrm{gb}}^{\mathrm{IU}}=\left(1-\mathrm{x}^{1 \mathrm{U}}\right) \cdot \mathrm{R}_{\mathrm{g}}^{\mathrm{IU}}$ & $\mathrm{R}_{\mathrm{gb}}^{2 \mathrm{U}}=\left(1-\mathrm{x}^{2 \mathrm{U}}\right) \cdot \mathrm{R}_{\mathrm{g}}^{2 \mathrm{U}}$ & $\mathrm{R}_{\mathrm{gb}}^{\mathrm{CX}}=\left(1-\mathrm{X}^{\mathrm{CX}}\right) \cdot \mathrm{R}_{\mathrm{g}}^{\mathrm{CX}}$ \\
\hline $\begin{array}{l}\text { The } R_{g g} \text { occurs between the } \\
\text { two (four) grout zones }\end{array}$ & $\mathrm{R}_{\mathrm{gg}}^{1 \mathrm{U}}=\frac{2 \cdot \mathrm{R}_{\mathrm{gb}}^{1 \mathrm{U}} \cdot\left(\mathrm{R}_{\mathrm{ar}}^{1 \mathrm{U}}-2 \cdot \mathrm{x}^{1 \mathrm{U}} \cdot \mathrm{R}_{\mathrm{g}}^{1 \mathrm{U}}\right)}{2 \cdot \mathrm{R}_{\mathrm{gb}}^{\mathrm{UU}}-\mathrm{R}_{\mathrm{ar}}^{1 \mathrm{U}}+2 \cdot \mathrm{x}^{1 \mathrm{U}} \cdot \mathrm{R}_{\mathrm{g}}^{1 \mathrm{U}}}$ & $\begin{array}{l}\mathrm{R}_{\mathrm{gg} 1}^{2 \mathrm{U}}=\frac{2 \cdot \mathrm{R}_{\mathrm{gb}}^{2 \mathrm{U}} \cdot\left(\mathrm{R}_{\mathrm{ar}, 1}^{2 \mathrm{U}}-2 \cdot \mathrm{x}^{2 \mathrm{U}} \cdot \mathrm{R}_{\mathrm{g}}^{2 \mathrm{U}}\right)}{2 \cdot \mathrm{R}_{\mathrm{gb}}^{2 \mathrm{U}}-\mathrm{R}_{\mathrm{ar}, 1}^{2 \mathrm{U}}+2 \cdot \mathrm{x}^{2 \mathrm{U}} \cdot \mathrm{R}_{\mathrm{g}}^{2 \mathrm{U}}} \\
\mathrm{R}_{\mathrm{gg} 2}^{2 \mathrm{U}}=\frac{2 \cdot \mathrm{R}_{\mathrm{gb}}^{2 \mathrm{U}} \cdot\left(\mathrm{R}_{\mathrm{ar}, 2}^{2 \mathrm{U}}-2 \cdot \mathrm{x}^{2 \mathrm{U}} \cdot \mathrm{R}_{\mathrm{g}}^{2 \mathrm{U}}\right)}{2 \cdot \mathrm{R}_{\mathrm{gb}}^{2 \mathrm{U}}-\mathrm{R}_{\mathrm{ar}, 2}^{2 \mathrm{U}}+2 \cdot \mathrm{x}^{2 \mathrm{U}} \cdot \mathrm{R}_{\mathrm{g}}^{2 \mathrm{U}}}\end{array}$ & $x$ \\
\hline $\begin{array}{l}\text { Thermal capacities of the } \\
\text { grout regions }\end{array}$ & $\mathrm{C}_{\mathrm{g}}^{\mathrm{lU}}=\rho_{\text {grout }} \cdot \frac{\pi}{4} \cdot\left(\frac{\mathrm{d}_{\mathrm{b}}^{2}}{2}-\mathrm{d}_{\mathrm{a}}^{2}\right) \cdot \mathrm{c}_{\mathrm{p}, \text { grout }}$ & $\mathrm{C}_{\mathrm{g}}^{2 \mathrm{U}}=\rho_{\text {grout }} \cdot \frac{\pi}{4} \cdot\left(\frac{\mathrm{d}_{\mathrm{b}}^{2}}{4}-\mathrm{d}_{\mathrm{a}}^{2}\right) \cdot \mathrm{c}_{\mathrm{p}, \text { grout }}$ & $\mathrm{C}_{\mathrm{g}}^{\mathrm{CX}}=\rho_{\text {grout }} \cdot \frac{\pi}{4} \cdot\left(\mathrm{d}_{\mathrm{b}}^{2}-\mathrm{d}_{\mathrm{a}, 2}^{2}\right) \cdot \mathrm{c}_{\mathrm{p}, \text { grout }}$ \\
\hline
\end{tabular}

\subsection{Modified TRCM (MTRCM) model}

To enhance the TRCM precision for the short-term response, Pasquier and Marcotte [131] refined the initial TRCM model [129, 130] by adding more capacities and resistances. The network with constant inlet, outlet and grout temperatures at the boundaries 
is shown in Fig.10. To validate the MTRCM model, ten scenarios of thermal properties are investigated using the 2D FEM model.

These scenarios denote the integration of different BHE radii, material thermal physical properties and pipe spacing.

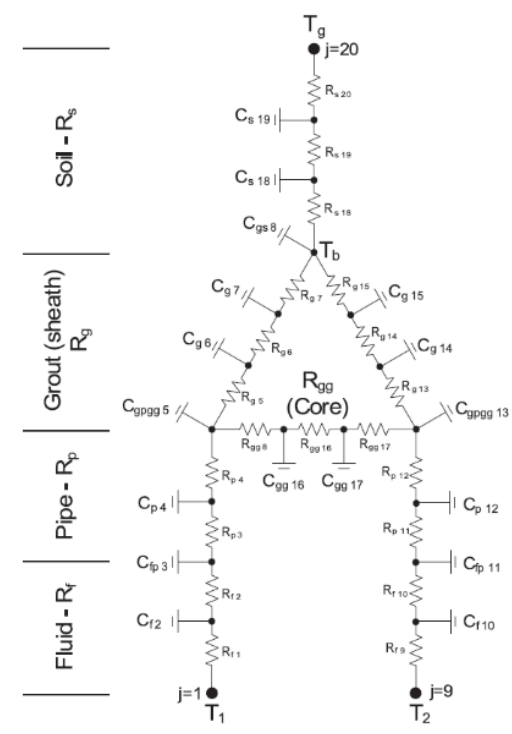

Fig. 10. The schematic diagram of the MTRCM model [130].

The results of the original TRCM are compared with the MTRCM model data as indicated in Fig.11. The figure shows a very good agreement as well as fast calculation of the temperature response. It is observed that the MTRCM model is highly enhanced compared with the original model.
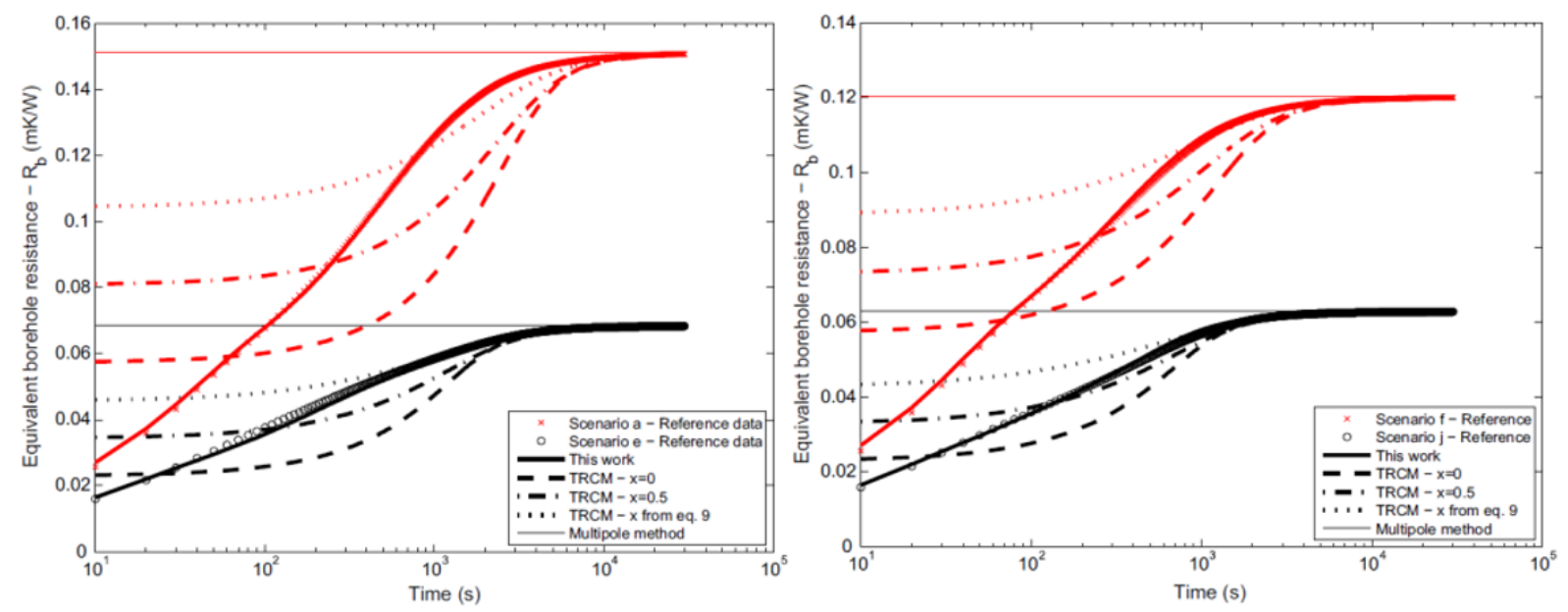

Fig. 11. The initial TRCM and the MTRCM results [131].

Biglarian et al. [132] developed a 2D radial-axial finite volume model to predict both long and short-term responses of the BHE, with the resistance-capacity network which is similar to that of the MTRCM [131]. Fig.12 depicts the model discretization scheme and its thermal resistance-capacity network. However, there are some differences between the TRCM and MTRCM, such as the capacity node location, the distributions of thermal capacities and resistances among these nodes. 


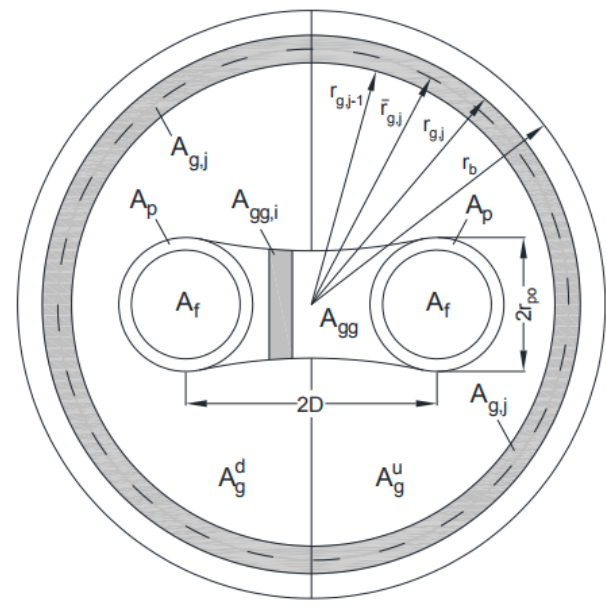

(a)

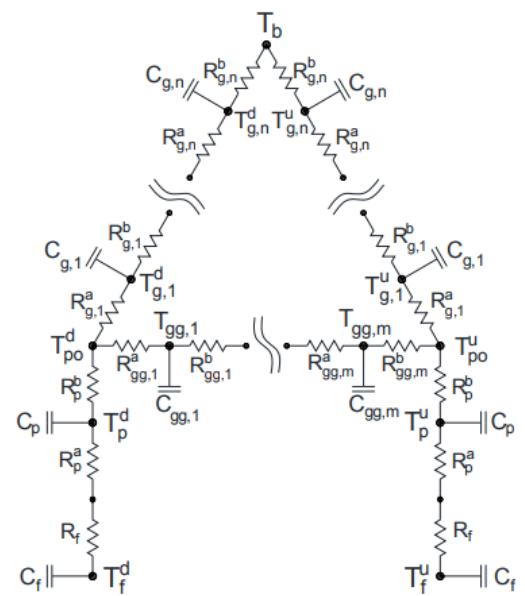

(b)

Fig.12. (a) Discretization scheme for the BHE cross-section; (b) thermal resistance-capacity network [132].

To improve the model accuracy, the grout sub-regions are divided into several sub-sections with their corresponding thermal capacities and resistances. The results indicate that the 2D radial-axial finite volume model has a good accuracy in predicting the BHE thermal response for a long time interval ranging from 1 minute to 10 years.

\subsection{Simplified TRCM (STRCM) model}

Minaei and Maerefat [133] presented a simplified TRCM model as a STRCM, in which the grout is treated as a single region, with four nodes within the BHE as shown in Fig.13.

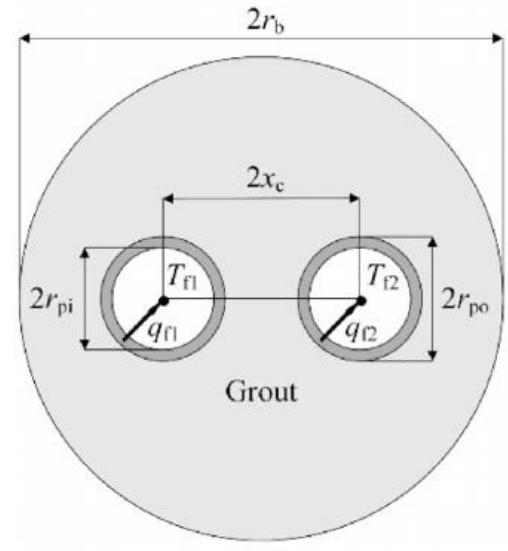

a

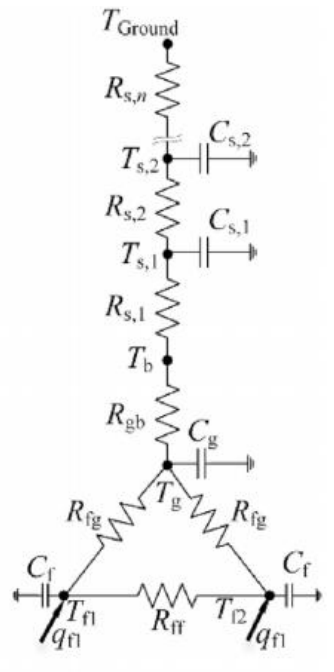

b

Fig.13. The schematic of the equivalent thermal networks: (a) BHE; (b) STRCM [133]. 

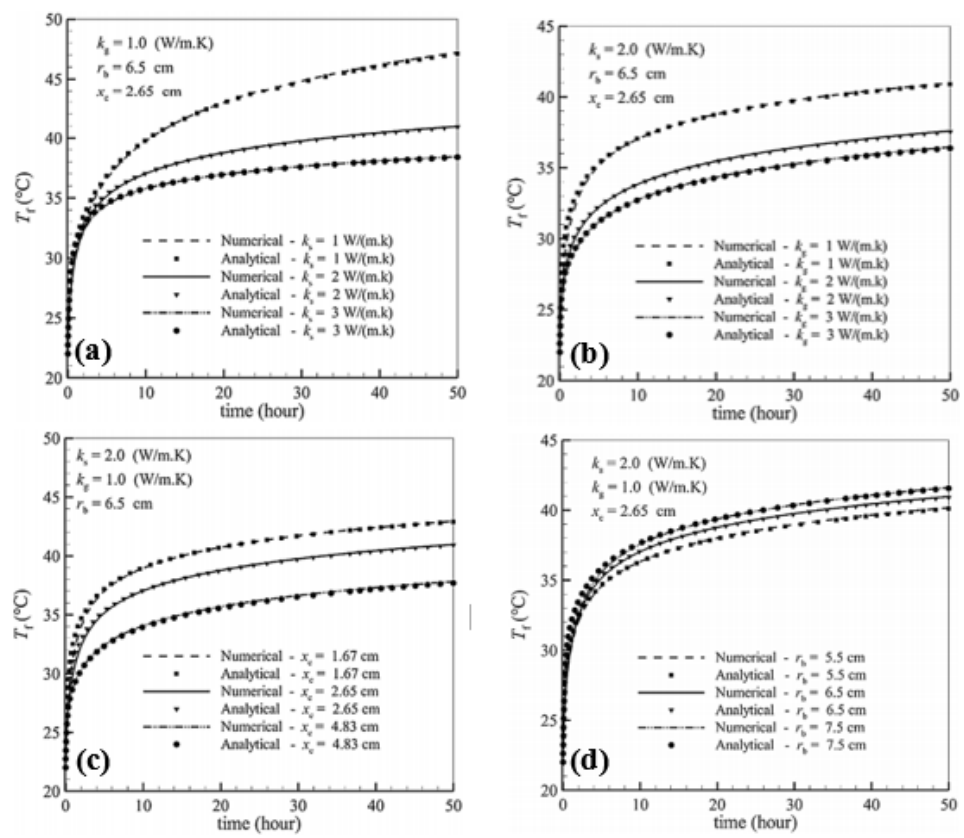

Fig.14. The effects of (a) soil thermal conductivity; (b) grout thermal conductivity; (c) shank spacing; (d) radii of BHE [133].

Fig.14 shows the effects of the shank spacing, radii of the borehole, grout thermal conductivity, soil thermal conductivity, on the fluid temperature. It is observed that the STRCM model accurately reflects the fluid temperature variation. Furthermore, this model is no complicated and there is no limitation on time step for the solution stability, for example, it produces accurate results even for the time step as large as one hour.

\subsection{Composite media infinite line source (CMILS) model}

Li et al. [67, 113] proposed a CMILS model for calculating the transient heat transfer processes of the BHEs and EPs based on Jaeger's method [134]. This CMILS model can precisely assess the impact of the grout heat capacity. Additionally, the model is also sufficiently flexible to study the different arrangements of channels, for example, spiral-coils, W-, single- and double-shaped [67]. As a result, it is essential to investigate these arrangements because most numerical models set various assumptions regarding the time features of the thermal procedure [135]. Unfortunately, this line-source model overlooks the influence of the heat capacity of the working fluid, which gives rise to some errors. Similarly, the CMILS model [67] is further refined into a form that facilitates the numerical calculations in order to meet the engineering requirements [113]. The new model is validated by the existing experimental results as shown in Figs. 15 and 16. It performs better in the short time operation than the traditional line-source model. Yang and Li [114] proposed a 2D CMILS FVM model to assess the short-term operation. The effects of heat capacities of the BHE, U-tube wall and working fluid are taken into account. The results reveal that this approach is applicable to the operating time shorter than 4 minutes and the system parameters have little influence on the short time behaviour. 

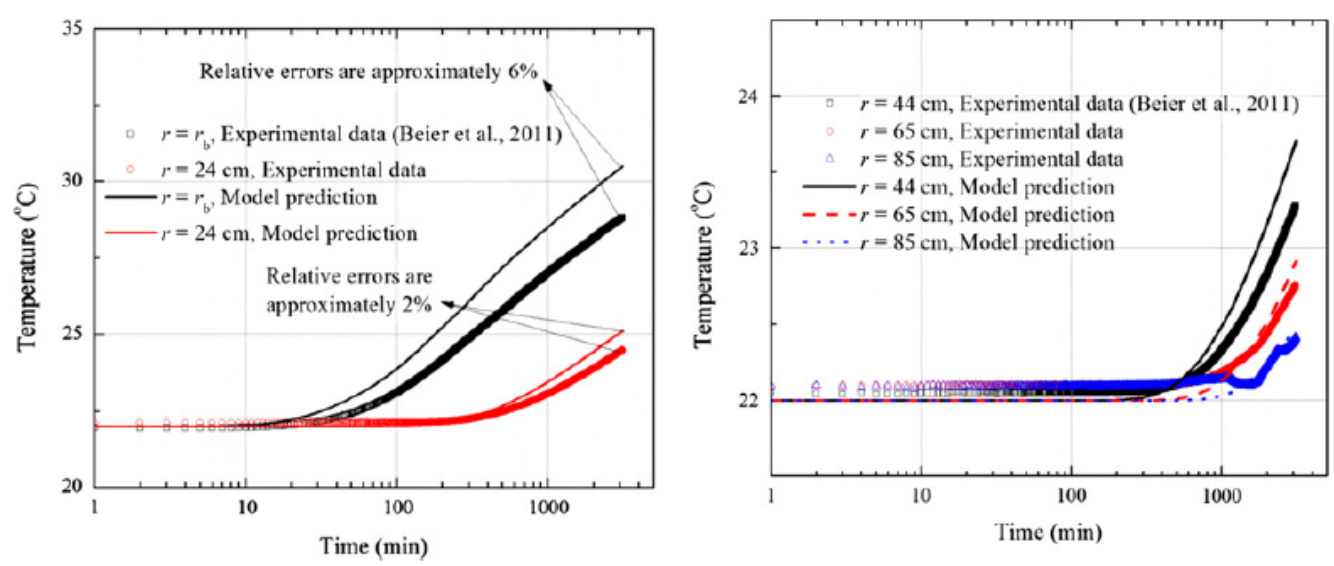

Fig.15. Temperature comparison between CMILS model and experimental results in different radial direction [113].
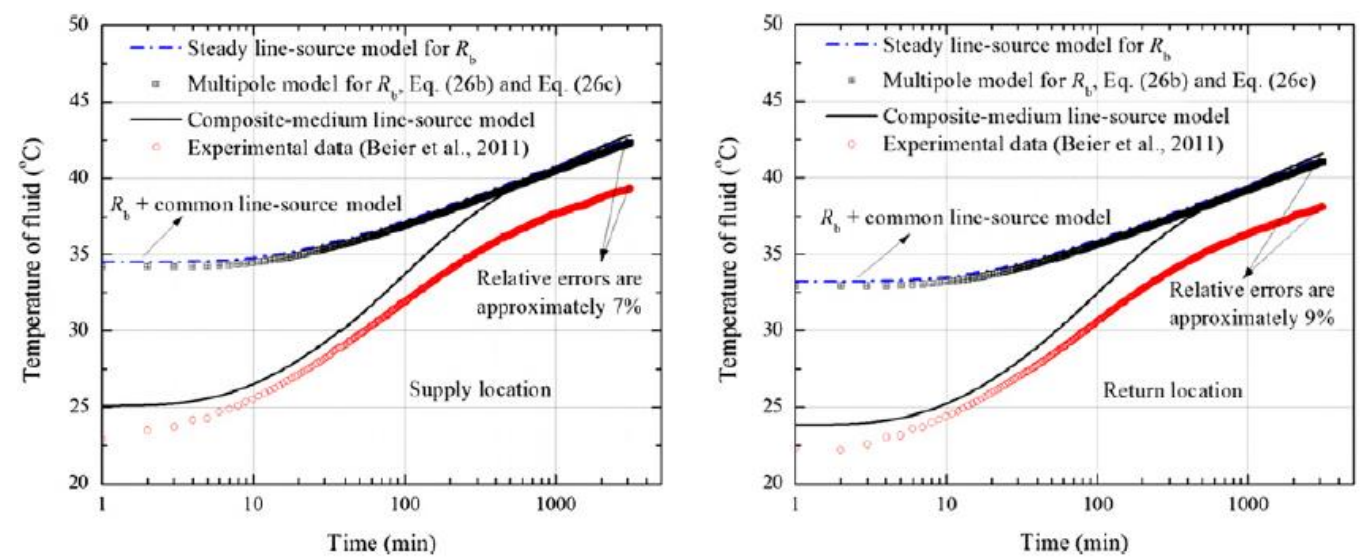

Fig. 16. Working fluid temperature comparison between CMILS model and experimental results [113].

\subsection{Summary of 2D models}

The 2D analytical models $[68,69]$ have been developed by making a number of simplifying assumptions and applied to the practical projects as shown in Table 3. The general assumptions include overlooking the geometry and BHE thermal capacity, rendering the model unsuitable for short-term application, neglecting heat transfer at the BHE bottom. Although the 2D analytical solutions require less computing effort, they are less suitable for the design and simulation tasks. The 2D models such as EWS [109], MISOS [110], CaRM [111], TRCM [129, 130] and CMILS [67, 113], DST [58], superposition borehole model (SBM) [136], can be used to analyse the steady state heat transfer in the plane perpendicular to the BHE, thus reducing the computational time $[58,136]$. Furthermore, many 2D models are available to evaluate a borehole's thermal resistance $\left(\mathrm{R}_{\mathrm{b}}\right)$, for instance the Paul's model [137], Sharquawy model [138], Line-source model [58] and Multipole model [139, 140]. 
Table 3 The comparison of 2D models.

\begin{tabular}{|c|c|c|c|c|c|c|}
\hline \multicolumn{7}{|c|}{ 2D models } \\
\hline \multirow{2}{*}{$\begin{array}{l}\text { Model } \\
\text { Name }\end{array}$} & \multirow[t]{2}{*}{ Ref. } & \multirow[t]{2}{*}{ Assumption conditions } & \multirow[t]{2}{*}{ Boundary conditions } & \multicolumn{3}{|c|}{ Special findings } \\
\hline & & & & Method used & Error analysis & Scope of Applications \\
\hline $\begin{array}{l}\text { 2D FVM } \\
\text { model }\end{array}$ & $\begin{array}{l}\text { Yavuzturk } \\
\mathrm{C}[78,79]\end{array}$ & $\begin{array}{l}\text { 1) The impacts at the soil surface } \\
\text { and bottom of the U-tube are } \\
\text { ignored; 2) Soil properties are } \\
\text { uniform; 3) The impacts of pipe } \\
\text { wall temperature variation with } \\
\text { the depth is estimated. }\end{array}$ & $\begin{array}{l}\text { 1) The undisturbed soil } \\
\text { temperature is assumed to } \\
\text { equal to the far-field } \\
\text { temperature; 2) The physical } \\
\text { region is regarded as a semi- } \\
\text { circular region; 3) A constant } \\
\text { heat flux is used in inlet and } \\
\text { outlet region; 4) The unit pipe } \\
\text { thermal resistance keeps a } \\
\text { constant. }\end{array}$ & $\begin{array}{l}\text { 1) Based on 2D fully implicit } \\
\text { FVM; 2) A 'Pie-sector' } \\
\text { approximation of the circular } \\
\text { pipe geometry is carried out; } 3 \text { ) } \\
\text { The convective heat transfer } \\
\text { coefficient is gained depended } \\
\text { upon the Dittus-Boelter } \\
\text { correlation. }\end{array}$ & $\begin{array}{l}\text { This approach enable } \\
\text { to calculate the pipe } \\
\text { surface temperature } \\
\text { with a mean relative } \\
\text { error of } \pm 1 \% \text { compared } \\
\text { with the analytical } \\
\text { solutions. }\end{array}$ & $\begin{array}{l}\text { 1) This model is applied to } \\
\text { calculate the BHE thermal } \\
\text { properties for the short-term } \\
\text { analysis; 2) This model is able } \\
\text { to calculate the non- } \\
\text { dimensional temperature } \\
\text { response factor for the short- } \\
\text { term analysis 3) This model is } \\
\text { utilized to study the transient } \\
\text { heat transfer model within the } \\
\text { vertical BHE for short } \\
\text { timescale response. }\end{array}$ \\
\hline $\begin{array}{l}\text { Equivalent } \\
\text { Diameter } \\
\text { Model }\end{array}$ & $\begin{array}{l}\text { Gu and } \\
\text { O’Neal } \\
{[107,115]}\end{array}$ & $\begin{array}{l}\text { 1) The steady state; 2) The } \\
\text { geometry is assumed as an } \\
\text { equivalent pipe diameter. }\end{array}$ & N/A & $\begin{array}{l}\text { A fully implicit FDM is used to } \\
\text { calculate the temperature } \\
\text { variation along with a pipe wall. }\end{array}$ & $\begin{array}{l}\text { The error analysis of } \\
\text { water temperature is } \\
0.5^{\circ} \mathrm{C} \text {. }\end{array}$ & $\begin{array}{l}\text { 1) The model is suitable to } \\
\text { simulate a single U-tube of } \\
\text { BHEs; 2) Focus on } \\
\text { developing a discretized } \\
\text { analytical model to estimate } \\
\text { the effect of grout on the } \\
\text { performance of a vertical U- } \\
\text { tube BHE. }\end{array}$ \\
\hline EWS model & $\begin{array}{l}\text { Wetter and } \\
\text { Huber [109] }\end{array}$ & $\begin{array}{l}\text { 1) Ignoring the heat flow in the } \\
\text { axial direction; 2) Each soil layer } \\
\text { has a constant thermal physical } \\
\text { property. }\end{array}$ & $\begin{array}{l}\text { Soil is assumed as constant } \\
\text { heat extraction. }\end{array}$ & $\begin{array}{l}\text { 1) TRNSYS with the Type } 451 \\
\text { module; 2) The Crank- } \\
\text { Nicholson Schema; 3) Using a } \\
\text { single lumped capacitance and } \\
\text { conduction method. }\end{array}$ & N/A & $\begin{array}{l}\text { 1) The model is suitable to } \\
\text { simulate a double U-tube pipe } \\
\text { of a BHE during the short- } \\
\text { term step period; 2) The } \\
\text { model is used to evaluate the } \\
\text { transient performance of a } \\
\text { single BHE with a double U- } \\
\text { tube pipe. }\end{array}$ \\
\hline $\begin{array}{l}\text { MISOS } \\
\text { model }\end{array}$ & $\begin{array}{l}\text { Oppelt et al. } \\
\text { [110] }\end{array}$ & $\begin{array}{l}\text { This model is depended on the } \\
\text { hypothesis that both inlet pipes are } \\
\text { close to each other. }\end{array}$ & $\begin{array}{l}\text { The element connects three } \\
\text { quarters of the circumference } \\
\text { of both inlet pipes, the soil and } \\
\text { core with half of the borehole } \\
\text { circumference as boundary. }\end{array}$ & $\begin{array}{l}\text { This grout region is classified } \\
\text { into three computational zones, } \\
\text { namely, the core region, the half } \\
\text { annulus surrounding the inlet } \\
\text { pipes and the half annulus } \\
\text { surrounding the outlet pipes. }\end{array}$ & $\begin{array}{l}\text { 1) The maximum } \\
\text { shank spacing was } \\
\text { found to cause the } \\
\text { biggest error, reaching } \\
\text { 15\%. 2) The minimal } \\
\text { shank spacing was } \\
\text { found to cause the } \\
\text { biggest error, reaching } \\
5 \% \text {. }\end{array}$ & $\begin{array}{l}\text { 1) MISOS model provides a } \\
\text { more detailed consideration } \\
\text { of the grout in BHE with } \\
\text { double U-tube pipe; } \\
\text { 2) It allows the fast simulation } \\
\text { of } 1 \text { year; } \\
\text { 3) The MISOS is applied to } \\
\text { calculate the heat distribution } \\
\text { in the BHE with double U- } \\
\text { tube pipe. }\end{array}$ \\
\hline
\end{tabular}




\begin{tabular}{|c|c|c|c|c|c|c|}
\hline $\begin{array}{l}\text { CaRM } \\
\text { model }\end{array}$ & $\begin{array}{l}\text { Carli et al. } \\
\text { [111] }\end{array}$ & $\begin{array}{l}\text { 1) For soil region, it is regarded as } \\
\text { heat conduction without time; 2) } \\
\text { The undisturbed soil temperatures } \\
\text { are regarded as independent of } \\
\text { time; 3) Heat flux along the } \\
\text { vertical direction is ignored, while } \\
\text { it is taken into account along the } \\
\text { radial direction; 4) The thermal } \\
\text { capacity of the ground is } \\
\text { considered, but the thermal } \\
\text { capacity of grout and working } \\
\text { fluid are ignored; 5) Heat transfer } \\
\text { at the bottom of the BHE and soil } \\
\text { is not considered; 6)Thermal } \\
\text { resistance is assumed without } \\
\text { time; 7) The BHE wall } \\
\text { temperature is assumed as } \\
\text { uniform. }\end{array}$ & $\begin{array}{l}\text { 1) The temperature is regarded } \\
\text { as equivalent to the } \\
\text { undisturbed soil temperature at } \\
\mathrm{r}>\mathrm{r} \text {-max; 2) Assumed the } \\
\text { annual average temperature is } \\
\text { defined as boundary at the soil } \\
\text { surface; 3) This mean working } \\
\text { fluid temperature is assumed } \\
\text { equivalent to the outlet } \\
\text { temperature; } 4 \text { ) The maximum } \\
\text { radius is assumed as } 10 \mathrm{~m} ; 5) \\
\text { The undisturbed soil } \\
\text { temperature has been set to } \\
13.3^{\circ} \mathrm{C} \text { and flow rate is } 0.64 \\
\mathrm{~kg} / \mathrm{s} \text {. }\end{array}$ & $\begin{array}{l}\text { 1) Depended upon the electrical } \\
\text { analogy; 2) a local steady state } \\
\text { heat transfer is taken into } \\
\text { account; 3) For soil region, the } \\
\text { discretized differential equations } \\
\text { are obtained by FVM; 4) For } \\
\text { BHE region, the discretized } \\
\text { differential equations are solved } \\
\text { by FEM. }\end{array}$ & $\begin{array}{l}\text { The soil temperature } \\
\text { error is about } 0.35^{\circ} \mathrm{C} \\
\text { between numerical and } \\
\text { test results. }\end{array}$ & $\begin{array}{l}\text { 1) CaRM model can simulate } \\
\text { the performance of the BHEs } \\
\text { with the single, double and } \\
\text { coaxial pipes under transient } \\
\text { conditions; 2) CaRM method } \\
\text { is applied to analyze the } \\
\text { working fluid and the soil } \\
\text { temperature variation at } \\
\text { various depths and distances } \\
\text { from the axis of BHE; 3) } \\
\text { CaRM model can calculate } \\
\text { soil temperature in time and } \\
\text { space. }\end{array}$ \\
\hline $\begin{array}{l}\text { CMILS } \\
\text { model }\end{array}$ & $\begin{array}{c}\text { Yang and } \mathrm{Li} \\
\text { [114] }\end{array}$ & $\begin{array}{l}\text { Through these heat balance } \\
\text { equations, the time scale can be } \\
\text { calculated by } \mathrm{t} \sim(\Delta \mathrm{r})^{2} / \alpha \mathrm{l} \text {. }\end{array}$ & $\begin{array}{l}\text { Region } r<r_{b} \text { denotes one } \\
\text { medium; region } r>r_{b} \text { denotes } \\
\text { another medium. }\end{array}$ & $\begin{array}{l}\text { Based on the Jaeger's method, as } \\
\text { well as, the infinite line-source } \\
\text { theory in composite solids. }\end{array}$ & $\begin{array}{l}\text { 1) This maximum } \\
\text { difference is about } 6 \% \\
\text { at the location of BHE } \\
\text { wall between } \\
\text { numerical results } \\
\text { model and testing data; } \\
2) \text { The relative errors } \\
\text { are all smaller than } \\
10 \% ; 3) \text { The absolute } \\
\text { errors are about } \\
2 \sim 3{ }^{\circ} \mathrm{C} \text {. }\end{array}$ & $\begin{array}{l}\text { 1) CMILS model is for } \\
\text { calculating transient heat } \\
\text { transfer processes of BHEs } \\
\text { and energy piles during short- } \\
\text { term operation period; } 2 \text { ) To } \\
\text { analyse transient heat transfer } \\
\text { inside and outside BHE. }\end{array}$ \\
\hline $\begin{array}{l}\text { Improvement } \\
\text { CaRM }\end{array}$ & $\begin{array}{l}\text { Zerrella et } \\
\text { al. [125] }\end{array}$ & $\begin{array}{l}\text { 1) For soil region, it is regarded as } \\
\text { pure heat conduction without time; } \\
\text { 2) Heat flux along the radial } \\
\text { direction is taken into account; 3) } \\
\text { Thermal resistance is assumed } \\
\text { without time; 4) The ground } \\
\text { thermal conductivity is assumed } \\
\text { about } 1.75 \mathrm{~W} /(\mathrm{m} \cdot \mathrm{K}) \text {; 5) The } \\
\text { ground heat capacity is assumed } \\
\text { about } 2.4 \mathrm{MJ} /\left(\mathrm{m}^{3} \cdot \mathrm{K}\right) \text {. }\end{array}$ & $\begin{array}{l}\text { 1) The temperature is regarded } \\
\text { as equivalent to the } \\
\text { undisturbed soil temperature at } \\
\mathrm{r}>\mathrm{r} \text {-max; 2) The maximum } \\
\text { radius is assumed as } 3.5 \mathrm{~m} \text {; } \\
3 \text { The undisturbed soil } \\
\text { temperature has been set to } \\
15^{\circ} \mathrm{C} \text { and flow rate is } 0.76 \\
\mathrm{~kg} / \mathrm{s} \text {. }\end{array}$ & $\begin{array}{l}\text { 1) Depended upon the electrical } \\
\text { analogy; 2) The effect of the } \\
\text { thermal capacities of BHE is } \\
\text { considered; 3) Thermal core } \\
\text { node is used; 4) The BHE wall } \\
\text { heat balance equation is } \\
\text { modified. }\end{array}$ & $\begin{array}{l}\text { The outlet fluid } \\
\text { temperature difference } \\
\text { between simulated and } \\
\text { measured reaches a } \\
\text { maximum value of } 1 \mathrm{~K} .\end{array}$ & $\begin{array}{l}\text { 1) The thermal capacities of } \\
\text { the grout and of the working } \\
\text { fluid are considered; 2) To } \\
\text { resolve the heat conduction } \\
\text { equation under transient state } \\
\text { for the double pipe loops; } 3 \text { ) } \\
\text { To resolve the heat transfer } \\
\text { for the short time analysis; 4) } \\
\text { Short-time step simulations. }\end{array}$ \\
\hline CaRM-He & $\begin{array}{l}\text { Zerrella et } \\
\text { al. [126] }\end{array}$ & $\begin{array}{l}\text { 1) Heat conduction is occurred in } \\
\text { the radial direction on the deep and } \\
\text { surface regions; 2) 2D heat } \\
\text { conduction occurs within the } \\
\text { borehole zone; } 3 \text { ) The absorptivity }\end{array}$ & $\begin{array}{l}\text { 1)The ambient air temperature } \\
\text { is regarded as boundary } \\
\text { condition at the soil surface; } \\
\text { 2) The undisturbed soil } \\
\text { temperature }\left(8^{\circ} \mathrm{C}\right) \text { is regarded }\end{array}$ & $\begin{array}{l}\text { 1) The axial heat transfer and the } \\
\text { weather conditions are } \\
\text { considered; 2) Considering the } \\
\text { the effect of the pitch between } \\
\text { the turns of the helical pipe. }\end{array}$ & $\begin{array}{l}\text { The maximum } \\
\text { difference on } \mathrm{BHE} \\
\text { wall temperature is } \\
\text { equal to around } 1^{\circ} \mathrm{C} \text {. }\end{array}$ & $\begin{array}{l}\text { 1) CaRM-He model is used to } \\
\text { analyse the thermal } \\
\text { performance of the helical } \\
\text { BHE with short length; 2) To }\end{array}$ \\
\hline
\end{tabular}




\begin{tabular}{|c|c|c|c|c|c|c|}
\hline & & $\begin{array}{l}\text { and the emittance of the soil } \\
\text { surface are supposed equal to } 0.7 \\
\text { and } 0.9 \text {, respectively. }\end{array}$ & $\begin{array}{l}\text { as boundary condition at } 10 \mathrm{~m} \\
\text { beyond the bottom of the } \mathrm{BHE} \text {. }\end{array}$ & & & $\begin{array}{l}\text { analyse the short-time step } \\
\text { simulations. }\end{array}$ \\
\hline $\begin{array}{l}\text { TRCM } \\
\text { model }\end{array}$ & $\begin{array}{l}\text { Bauer et al. } \\
{[129,130]}\end{array}$ & $\begin{array}{l}\text { 1) The BHE wall is shown with } \\
\text { one single node. 2) The BHE } \\
\text { nearby ground is regarded as } 1 \mathrm{D} \\
\text { model by a FEM. }\end{array}$ & $\begin{array}{l}\text { This boundary conditions: } \\
\qquad \mathrm{C}_{\mathrm{j}}=\sum_{\mathrm{k}=1}^{\mathrm{n}_{\mathrm{j}}} \frac{\rho_{\mathrm{k}} \mathrm{c}_{\mathrm{k}} \mathrm{v}_{\mathrm{k}}}{\mathrm{R}_{\mathrm{k}}}, \mathrm{j}=1 \ldots \mathrm{n}\end{array}$ & $\begin{array}{l}\text { 1) Based on the delta-circuit } \\
\text { model and the multipole method. }\end{array}$ & $\begin{array}{l}\text { The difference of } \\
\text { TRCM presents only } \\
\text { about } 5.8 \% \text {. }\end{array}$ & $\begin{array}{l}\text { 1) The TRCM model is great } \\
\text { suited for combination into } \\
\text { unsteady state heat transfer } \\
\text { simulation programs; 2) The } \\
\text { TRCM model is capable of } \\
\text { achieving a higher precision } \\
\text { in depicting the heat transfer } \\
\text { process for different } \\
\text { configurations of the BHE; } 3 \text { ) } \\
\text { To determine the BHE } \\
\text { performance for the short- } \\
\text { time operation. }\end{array}$ \\
\hline $\begin{array}{l}\text { MTRCM } \\
\text { model }\end{array}$ & $\begin{array}{l}\text { Pasquier } \\
\text { and } \\
\text { Marcotte } \\
\text { [131] }\end{array}$ & $\begin{array}{l}\text { This assumption condition is same } \\
\text { with the TRCM model. }\end{array}$ & $\begin{array}{l}\text { 1) The boundary conditions: } \\
C_{j}=\sum_{k=1}^{n_{j}} \frac{\rho_{k} c_{k} v_{k}}{R_{k}}, j=1 \ldots n \\
\text { 2) On the upper external } \\
\text { boundary, a semicircle of } \\
\text { radius } r_{s}=20 \mathrm{~m} \text {, a temperature } \\
\text { of } T_{g}=10^{\circ} \mathrm{C} \text { is used. }\end{array}$ & $\begin{array}{l}\text { 1) Based on the Delta-circuit and } \\
\text { original TRCM model; } \\
\text { 2) To better consider the spacing } \\
\text { between the pipes. }\end{array}$ & $\begin{array}{l}\text { This model precisely } \\
\text { obtains the results for } \\
\text { times as short as } 10 \mathrm{~s} \text {. }\end{array}$ & $\begin{array}{l}\text { 1) This MTRCM model could } \\
\text { concentration only on BHE } \\
\text { with single U-tube and could } \\
\text { readily be extended to other } \\
\text { BHE arrangements; 2) } \\
\text { MTRCM is to enhance the } \\
\text { accuracy for short times } \\
\text { response. }\end{array}$ \\
\hline DST model & $\begin{array}{l}\text { Claesson } \\
\text { and } \\
\text { Hellstrom } \\
\text { [140] }\end{array}$ & $\begin{array}{l}\text { 1) The soil region is assumed as a } \\
\text { pure heat conduction; 2) The soil } \\
\text { thermal properties can be regarded } \\
\text { as a constant values; 3) The } \\
\text { capacitive effects of soil, grout and } \\
\text { working fluid regions are } \\
\text { neglected; 4) The thermal } \\
\text { interaction is considered among } \\
\text { each borehole. }\end{array}$ & $\begin{array}{l}\text { 1) The pipe wall temperature } \\
\text { and heat flux are assumed as } \\
\text { constant values; } \\
\text { 2) The fluid enters a pipe with } \\
\text { a uniform velocity. }\end{array}$ & $\begin{array}{l}\text { 1) the heat flow between the } \\
\text { BHE wall and pipe wall is } \\
\text { calculated by a thermal } \\
\text { resistance ( } \Delta \text {-circuit); } 2) \text { The soil } \\
\text { storage volume with multiple } \\
\text { BHEs is divided into two } \\
\text { categories: "local" and "global" } \\
\text { region. }\end{array}$ & N/A & $\begin{array}{l}\text { 1) DST model is known as the } \\
\text { basically method, even } \\
\text { though it is usually used to } \\
\text { simulate large and compact } \\
\text { heat storages. 2) DST is } \\
\text { usually used to simulate large } \\
\text { and compact heat storages; } \\
\text { 3) DST can solve the issues } \\
\text { of short-term operation. }\end{array}$ \\
\hline B2G model & $\begin{array}{l}\text { Ruiz-Calvo } \\
\text { F, Rosa } \\
\text { M.D [141- } \\
\text { 143] }\end{array}$ & $\begin{array}{l}\text { 1) Neglecting vertical heat } \\
\text { conduction effect; 2) The } \\
\text { maximum thermal resistance is } \\
\text { assumed as a limit between the } \\
\text { pipe nodes. }\end{array}$ & Based on the BHE geometries. & $\begin{array}{l}\text { Depended upon a 2D thermal } \\
\text { network approach. }\end{array}$ & $\begin{array}{l}\text { A max absolute error of } \\
0.3 \mathrm{~K} \text { between test and } \\
\text { numerical results. }\end{array}$ & $\begin{array}{l}\text { 1) B2G model is utilized to } \\
\text { analyse the dynamic thermal } \\
\text { performance of each } \\
\text { component over a period of at } \\
\text { least } 10-15 \mathrm{hrs} \text {; 2) } \mathrm{B} 2 \mathrm{G} \text { model } \\
\text { is concentrated on the short- } \\
\text { time performance calculation; } \\
\text { 3) To reduce the number of }\end{array}$ \\
\hline
\end{tabular}




\begin{tabular}{|c|c|c|c|c|c|c|}
\hline & & & & & & $\begin{array}{l}\text { parameters as much as } \\
\text { possible. }\end{array}$ \\
\hline $\begin{array}{l}\text { A homespun } \\
\text { 2D model }\end{array}$ & $\begin{array}{l}\text { Kuzmic et } \\
\text { al. [144] }\end{array}$ & $\begin{array}{l}\text { 1) The grout within the BHE is } \\
\text { assumed as ground part; } 2 \text { ) A COP } \\
\text { of } 3.5 \text { is regarded as a constant } \\
\text { operating for heating and cooling } \\
\text { system. }\end{array}$ & $\begin{array}{l}\text { 1) This heat flux Neumann } \\
\text { boundary condition; } \\
\text { 2) A constant temperature } \\
\text { Dirichlet boundary. }\end{array}$ & $\begin{array}{l}\text { Based on equivalent u-tube } \\
\text { geometry, FVM and Gauss- } \\
\text { Seidel method. }\end{array}$ & $\begin{array}{l}\text { The model is verified } \\
\text { by test and an } \\
\text { analytical method with } \\
\text { the max error of } 5.8 \% \\
\text { and } 1.3 \% \text {, respectively. }\end{array}$ & $\begin{array}{l}\text { 1) The homespun 2D FVM } \\
\text { model could analyse heat } \\
\text { transfer in GSHP systems; 2) } \\
\text { B2G model is used to analyse } \\
\text { the soil fouling and ensures } \\
\text { appropriate long operation } \\
\text { time of the GSHP systems. }\end{array}$ \\
\hline $\begin{array}{l}\text { Semi- } \\
\text { analytical } \\
\text { model }\end{array}$ & $\begin{array}{l}\text { Belzile et } \\
\text { al. [145] }\end{array}$ & $\begin{array}{l}\text { 1) Soil thermal physical properties } \\
\text { is assumed as constant; 2) The soil } \\
\text { nearby a BHE is regarded as a } \\
\text { square control volume; 3) The } \\
\text { conduction issue is regarded as an } \\
\text { independent of depth. }\end{array}$ & $\begin{array}{l}\text { 1) The boundary temperature } \\
\text { is constant at } \mathrm{T}=\mathrm{T}_{\mathrm{a}} ; 2 \text { ) The } \\
\text { inner BHE is regarded at a } \\
\text { constant temperature } \mathrm{T}=\mathrm{T}_{\mathrm{b}} \text {. }\end{array}$ & $\begin{array}{l}\text { 1) Based on a 2D CVFDM; } \\
\text { 2) A point-by-point Gauss- } \\
\text { Seidel iterative approach. }\end{array}$ & $\begin{array}{l}\text { 1) The outlet fluid } \\
\text { temperature error } \\
\text { between DST model } \\
\text { and proposed model is } \\
\text { at most } 0.03^{\circ} \mathrm{C} \text {, with an } \\
\text { average of } 0.009^{\circ} \mathrm{C} ; 2 \text { ) } \\
\text { The absolute error } \\
\text { between DST model } \\
\text { and proposed model } \\
\text { peaked at } 0.15^{\circ} \mathrm{C} \text {, with } \\
\text { a mean of } 0.07^{\circ} \mathrm{C} \text {. }\end{array}$ & $\begin{array}{l}\text { The model permits } \\
\text { independent inlet conditions } \\
\text { for each BHE. }\end{array}$ \\
\hline $\begin{array}{l}\text { New 2D } \\
\text { analytical } \\
\text { model }\end{array}$ & $\begin{array}{l}\text { Lamarche } \\
\text { [146] }\end{array}$ & $\begin{array}{l}\text { The internal core is assumed to } \\
\text { become a well stirred fluid, with a } \\
\text { single bulk temperature. }\end{array}$ & $\begin{array}{l}\text { 1) Soil boundary condition: } \\
\mathrm{T}_{\mathrm{g}}(\mathrm{r}, 0)=\mathrm{T}_{\mathrm{s}}(\mathrm{r}, 0)=\mathrm{T}_{0} \\
\mathrm{~T}_{\mathrm{g}}\left(\mathrm{r}_{\mathrm{b}}, \mathrm{t}\right)=\mathrm{T}_{\mathrm{s}}\left(\mathrm{r}_{\mathrm{b}}, \mathrm{t}\right) \\
-\left.\mathrm{k}_{\mathrm{g}} \frac{\partial \mathrm{T}_{\mathrm{g}}}{\partial \mathrm{r}}\right|_{\mathrm{r}=\mathrm{r}_{\mathrm{b}}}=-\left.\mathrm{k}_{\mathrm{s}} \frac{\partial \mathrm{T}_{\mathrm{s}}}{\partial \mathrm{r}}\right|_{\mathrm{r}=\mathrm{r}_{\mathrm{b}}} \\
\text { 2) Inner core boundary } \\
\text { condition: } \\
\pi \mathrm{r}_{\mathrm{r}}^{2}\left(\rho \mathrm{C}_{\mathrm{p}}\right)_{\mathrm{f}} \frac{\mathrm{dT}_{\mathrm{f}}}{\mathrm{dt}}=\mathrm{q}_{\mathrm{b}}^{\prime}+\left.2 \pi \mathrm{r}_{\mathrm{e}} \mathrm{k}_{\mathrm{g}} \frac{\mathrm{dT} \mathrm{g}}{\mathrm{dr}}\right|_{\mathrm{r}=\mathrm{r}_{\mathrm{e}}} \\
\frac{\mathrm{T}_{\mathrm{f}}-\mathrm{T}_{\mathrm{g}}}{\mathrm{R}_{\mathrm{p}}^{\prime}}=-\left.2 \pi \mathrm{r}_{\mathrm{e}} \mathrm{k}_{\mathrm{g}} \frac{\mathrm{dT} \mathrm{g}}{\mathrm{dr}}\right|_{\mathrm{r}=\mathrm{r}_{\mathrm{e}}}\end{array}$ & $\begin{array}{l}\text { Depended upon the concept of } \\
\text { equivalent radius. }\end{array}$ & $\begin{array}{l}\text { The error is agreement } \\
\text { with the result of Javed } \\
\text { and Claesson' model } \\
\text { and the modified } \\
\text { version of Beier and } \\
\text { Smith' model. }\end{array}$ & $\begin{array}{l}\text { 1) This model could easily } \\
\text { gain outcomes for various } \\
\text { arrangements and time scales; } \\
\text { 2) This model could solve } \\
\text { heat transfer issue between } \\
\text { working fluid and ground. }\end{array}$ \\
\hline
\end{tabular}




\section{3D heat transfer models of BHEs}

The 3D representations should be considered for an accurate BHE model. A great number of 3D numerical models have been developed based on the numerical approaches, such as FEM [112, 140, 147], FVM [148-151] and FDM [152-154]. In terms of the computational requirements, many methods are used to decrease the grids of the BHE elements, including Al-Khoury model [99-101], Nabi model [151, 152], Mottaghy and Dijkshoorn model [153], Diersch model [154, 155], Cui model [156], 3D MTRCM [131] and MDF models [157-159]. This section describes a detailed review on 3D heat transfer models for the vertical BHE system.

\subsection{Al-Khoury model}

Al-Khoury et al. [99, 100] presented two 3D models for a single U-tube BHE by the FEM. In the first model, a novel 1D heat pipe component along the BHE depth is adopted to analyze a virtual 3D heat flow within a normal BHE whereas in the second one, a 3D element is used to evaluate the groundwater flow and coupled heat transfer. The thermal interaction between two legs of the U-tube is considered in the partial differential equations by using a $1 \mathrm{D}$ model to represent the BHE heat transfer. Consequently, Al-Khoury et al. [100] extended the model to a 3D transient heat flow model for the vertical BHE with a double U-tube loop. The governing differential equations for the single and double U-tubes are shown in Table 4, expressed in terms of the heat flow, groundwater flow, energy conservation, initial and boundary conditions.

These two models address the steady and transient heat flows for a shallow geothermal system. The focus is placed on the vertical single and double U-tubes as well as their thermal interactions. Afterwards, Al-Khoury et al. [101] developed a 3D transient heat transfer model for multiple BHEs, which is verified by the experimental results gained from a shallow BHE system. This model is applied to analyse the thermal interactions among the BHEs components. Meanwhile, the effects of thermal resistance and the FEM discretization are also studied by using the energy balance equations. 
Table 4 The governing differential equations for the single and double U-tubes [99, 100].

\begin{tabular}{|c|c|c|c|}
\hline Ref. & The heat flow rate within soil region & The conductive-convective heat flow within the BHE region & Initial and boundary conditions \\
\hline $\begin{array}{l}\text { Steady state heat } \\
\text { transfer [99] }\end{array}$ & $\begin{array}{l}\text { For a steady state heat transfer, the equation is } \\
\text { given as: } \\
\rho_{\mathrm{w}} \mathrm{c}_{\mathrm{w}}\left(\mathrm{q}_{\mathrm{x}} \frac{\partial \mathrm{T}_{\mathrm{s}}}{\partial \mathrm{x}}+\mathrm{q}_{\mathrm{y}} \frac{\partial \mathrm{T}_{\mathrm{s}}}{\partial \mathrm{y}}+\mathrm{q}_{\mathrm{z}} \frac{\partial \mathrm{T}_{\mathrm{s}}}{\partial \mathrm{z}}\right) \\
-\lambda_{\mathrm{x}} \frac{\partial^{2} \mathrm{~T}_{\mathrm{s}}}{\partial \mathrm{x}^{2}}-\lambda_{\mathrm{y}} \frac{\partial^{2} \mathrm{~T}_{\mathrm{s}}}{\partial \mathrm{y}^{2}}-\lambda_{\mathrm{z}} \frac{\partial^{2} \mathrm{~T}_{\mathrm{s}}}{\partial \mathrm{z}^{2}}-\mathrm{H}=0\end{array}$ & $\begin{array}{l}\text { For a steady state, this net heat flow into BHE components is written as: } \\
\frac{\partial \mathrm{q}_{\mathrm{iz}}}{\partial \mathrm{z}} \mathrm{dV}_{\mathrm{i}}=\mathrm{b}_{\mathrm{io}}\left(\mathrm{T}_{\mathrm{i}}-\mathrm{T}_{\mathrm{o}}\right) \mathrm{dS}_{\mathrm{io}}+\mathrm{b}_{\mathrm{ig}}\left(\mathrm{T}_{\mathrm{i}}-\mathrm{T}_{\mathrm{g}}\right) \mathrm{dS}_{\mathrm{ig}} \\
\frac{\partial \mathrm{q}_{\mathrm{oz}}}{\partial \mathrm{z}} \mathrm{dV}_{\mathrm{o}}=\mathrm{b}_{\mathrm{oi}}\left(\mathrm{T}_{\mathrm{o}}-\mathrm{T}_{\mathrm{i}}\right) \mathrm{dS}_{\mathrm{oi}}+\mathrm{b}_{\mathrm{og}}\left(\mathrm{T}_{\mathrm{o}}-\mathrm{T}_{\mathrm{g}}\right) \mathrm{dS}_{\mathrm{og}} \\
\frac{\partial \mathrm{q}_{\mathrm{gz}}}{\partial \mathrm{z}} \mathrm{dV}_{\mathrm{g}}=\mathrm{b}_{\mathrm{gi}}\left(\mathrm{T}_{\mathrm{g}}-\mathrm{T}_{\mathrm{i}}\right) \mathrm{dS}_{\mathrm{gi}}+\mathrm{b}_{\mathrm{go}}\left(\mathrm{T}_{\mathrm{g}}-\mathrm{T}_{\mathrm{o}}\right) \mathrm{dS}_{\mathrm{go}}\end{array}$ & $\begin{array}{l}\text { The first condition: } \\
\mathrm{T}=\mathrm{T}(\mathrm{z}) \mathrm{T}_{\mathrm{i}}=\mathrm{T}(\mathrm{z}=0) \\
\text { The second condition: } \\
-\lambda_{\mathrm{g}} \frac{\partial \mathrm{T}_{\mathrm{g}}}{\partial \mathrm{n}}=\mathrm{b}_{\mathrm{sg}}\left(\mathrm{T}_{\mathrm{g}}-\mathrm{T}_{\mathrm{s}}\right)\end{array}$ \\
\hline $\begin{array}{l}\text { Transient heat } \\
\text { transfer [100] }\end{array}$ & $\begin{array}{l}\text { For a transient heat transfer, the equation is given } \\
\text { as: } \\
\rho \mathrm{c} \frac{\partial \mathrm{T}_{\mathrm{s}}}{\partial \mathrm{t}}+\rho_{\mathrm{w}} \mathrm{c}_{\mathrm{w}}\left(\mathrm{q}_{\mathrm{x}} \frac{\partial \mathrm{T}_{\mathrm{s}}}{\partial \mathrm{x}}+\mathrm{q}_{\mathrm{y}} \frac{\partial \mathrm{T}_{\mathrm{s}}}{\partial \mathrm{y}}+\mathrm{q}_{\mathrm{z}} \frac{\partial \mathrm{T}_{\mathrm{s}}}{\partial \mathrm{z}}\right) \\
-\lambda_{\mathrm{x}} \frac{\partial^{2} \mathrm{~T}_{\mathrm{s}}}{\partial \mathrm{x}^{2}}-\lambda_{\mathrm{y}} \frac{\partial^{2} \mathrm{~T}_{\mathrm{s}}}{\partial \mathrm{y}^{2}}-\lambda_{\mathrm{z}} \frac{\partial^{2} \mathrm{~T}_{\mathrm{s}}}{\partial \mathrm{z}^{2}}-\mathrm{H}=0\end{array}$ & $\begin{array}{l}\text { For a transient state, the net heat flow into BHE components is written } \\
\text { as: } \\
\rho c_{\mathrm{r}} \frac{\partial \mathrm{T}_{\mathrm{i}, 1}}{\partial \mathrm{t}} \mathrm{dV}_{\mathrm{i}, 1}-\lambda_{\mathrm{r}} \frac{\mathrm{d}^{2} \mathrm{~T}_{\mathrm{i}, 1}}{\mathrm{dz}^{2}} \mathrm{dV}_{\mathrm{i}, 1}+\rho \mathrm{c}_{\mathrm{r}} \mathrm{u} \frac{\partial \mathrm{T}_{\mathrm{i}, 1}}{\partial \mathrm{z}} \mathrm{dV}_{\mathrm{i}, 1}=\mathrm{b}_{\mathrm{i}, \mathrm{g}}\left(\mathrm{T}_{\mathrm{i}, 1}-\mathrm{T}_{\mathrm{g}}\right) \mathrm{dS}_{\mathrm{ig}, 1} \\
\rho \mathrm{c}_{\mathrm{r}} \frac{\partial \mathrm{T}_{\mathrm{i}, 2}}{\partial \mathrm{t}} \mathrm{dV}_{\mathrm{i}, 2}-\lambda_{\mathrm{r}} \frac{\mathrm{d}^{2} \mathrm{~T}_{\mathrm{i}, 2}}{\mathrm{dz}^{2}} \mathrm{dV}_{\mathrm{i}, 2}+\rho \mathrm{c}_{\mathrm{r}} \mathrm{u} \frac{\partial \mathrm{T}_{\mathrm{i}, 2}}{\partial \mathrm{z}} \mathrm{dV}_{\mathrm{i}, 2}=\mathrm{b}_{\mathrm{i}, \mathrm{g} 2}\left(\mathrm{~T}_{\mathrm{i}, 2}-\mathrm{T}_{\mathrm{g}}\right) \mathrm{dS}_{\mathrm{ig}, 2} \\
\rho \mathrm{c}_{\mathrm{r}} \frac{\partial \mathrm{T}_{\mathrm{o}, 1}}{\partial \mathrm{t}} \mathrm{dV}_{\mathrm{o}, 1}-\lambda_{\mathrm{r}} \frac{\mathrm{d}^{2} \mathrm{~T}_{\mathrm{o}, 1}}{\mathrm{dz}^{2}} \mathrm{dV}_{\mathrm{o}, 1}+\rho \mathrm{c}_{\mathrm{r}} \mathrm{u} \frac{\partial \mathrm{T}_{\mathrm{o}, 1}}{\partial \mathrm{z}} \mathrm{dV}_{\mathrm{o}, 1}=\mathrm{b}_{\mathrm{o}, \mathrm{g} 1}\left(\mathrm{~T}_{\mathrm{o}, 1}-\mathrm{T}_{\mathrm{g}}\right) \mathrm{dS}_{\mathrm{og}, 1} \\
\rho \mathrm{c}_{\mathrm{r}} \frac{\partial \mathrm{T}_{\mathrm{o}, 2}}{\partial \mathrm{t}} \mathrm{dV}_{\mathrm{o}, 2}-\lambda_{\mathrm{r}} \frac{\mathrm{d}^{2} \mathrm{~T}_{\mathrm{o}, 2}}{\mathrm{dz}^{2}} \mathrm{dV}_{\mathrm{o}, 2}+\rho \mathrm{c}_{\mathrm{r}} \mathrm{u} \frac{\partial \mathrm{T}_{\mathrm{o}, 2}}{\partial \mathrm{z}} \mathrm{dV}_{\mathrm{o}, 2}=\mathrm{b}_{\mathrm{o}, \mathrm{g} 2}\left(\mathrm{~T}_{\mathrm{o}, 2}-\mathrm{T}_{\mathrm{g}}\right) \mathrm{dS}_{\mathrm{og}, 2} \\
\rho \mathrm{c}_{\mathrm{g}} \frac{\partial \mathrm{T}_{\mathrm{g}}}{\partial \mathrm{t}} \mathrm{dV}_{\mathrm{g}}-\lambda_{\mathrm{g}} \frac{\mathrm{d}^{2} \mathrm{~T}_{\mathrm{g}}}{\mathrm{dZ^{2 }}} \mathrm{dV}_{\mathrm{g}} \\
=\mathrm{b}_{\mathrm{ig}, 1}\left(\mathrm{~T}_{\mathrm{g}}-\mathrm{T}_{\mathrm{i}, 1}\right) \mathrm{dS}_{\mathrm{ig}, 1}+\mathrm{b}_{\mathrm{ig}, 2}\left(\mathrm{~T}_{\mathrm{g}}-\mathrm{T}_{\mathrm{i}, 2}\right) \mathrm{dS}_{\mathrm{ig}, 2} \\
+\mathrm{b}_{\mathrm{og}, 1}\left(\mathrm{~T}_{\mathrm{g}}-\mathrm{T}_{\mathrm{o}, 1}\right) \mathrm{dS}_{\mathrm{og}, 1}+\mathrm{b}_{\mathrm{og}, 2}\left(\mathrm{~T}_{\mathrm{g}}-\mathrm{T}_{\mathrm{o}, 2}\right) \mathrm{dS}_{\mathrm{og}, 2}\end{array}$ & $\begin{array}{l}\text { Initial condition: at time } \mathrm{t}=0 \text {, the } \\
\text { temperature variation in the heat pipe } \\
\text { is shown as: } \mathrm{T}=\mathrm{T}_{\mathrm{s}}(\mathrm{z}, 0) \\
\text { The first condition: } \mathrm{T}=\mathrm{T}(\mathrm{z}, \mathrm{t}) \\
\text { The second condition: } \\
-\lambda_{\mathrm{g}} \frac{\partial \mathrm{T}_{\mathrm{g}}}{\partial \mathrm{n}}=\mathrm{b}_{\mathrm{sg}}\left(\mathrm{T}_{\mathrm{g}}-\mathrm{T}_{\mathrm{s}}\right)\end{array}$ \\
\hline
\end{tabular}




\subsection{Nabi FVM model}

A 3D transient heat transfer model based on the FVM for shallow geothermal systems is proposed by Nabi and Al-Khoury [151, 152]. Two regions are adopted in this model, one representing the soil region, and another represents the BHE region. The influence of groundwater on the soil layer, the impact of working fluid on heat transfer rate, and the thermal interaction between the BHE and the nearby soil are considered in this model. For the soil region, the governing equations are discretized through an integration of a local Cartesian mesh and a multigrid with the hierarchical tree data arrangement. The groundwater flow is assumed to be at steady-state and the heat exchange occurs within a fully confined ground layer, for which the trainset soil heat transfer equations, initial and boundary conditions are presented in Table 5.

Table 5 The trainset heat transfer equations of the soil, BHE, initial and boundary conditions [151, 152].

\begin{tabular}{|c|c|}
\hline Soil heat and continuity equations & $\begin{array}{l}\text { The unsteady state heat flow equation is written as: } \\
\rho c \frac{\partial T}{\partial t}=\nabla(\lambda \cdot \nabla T)-\nabla\left(\rho_{\mathrm{w}} \cdot \mathrm{c}_{\mathrm{w}} \cdot \mathrm{r} \cdot \mathrm{T}\right)+\mathrm{H}(\mathrm{x}, \mathrm{y}, \mathrm{z})\end{array}$ \\
\hline \multirow{4}{*}{ Soil boundary and initial conditions } & $\begin{array}{l}\text { In terms of the fluid flow, the initial condition in the soil, at time }=0 \text {, is given as: } \\
\varphi(\mathrm{x}, \mathrm{y}, \mathrm{z}, 0)=\varphi_{0}(\mathrm{x}, \mathrm{y}, \mathrm{z})\end{array}$ \\
\hline & $\begin{array}{l}\text { The boundary condition is given as: } \\
\varphi(\mathrm{x}=0, \mathrm{y}, \mathrm{z})=\varphi_{1}, \text { on } \mathrm{x}=0 \text { surface } \\
\varphi(\mathrm{x}=\mathrm{L}, \mathrm{y}, \mathrm{z})=\varphi_{2}, \text { on } \mathrm{x}=\mathrm{L} \text { surface }\end{array}$ \\
\hline & $\begin{array}{l}\text { In terms of the heat flow, the initial condition in the soil, at time }=0 \text {, is given as the } \\
\text { steady-state condition: } \\
\mathrm{T}(\mathrm{x}, \mathrm{y}, \mathrm{z}, 0)=\mathrm{f}(\mathrm{x}, \mathrm{y}, \mathrm{z})\end{array}$ \\
\hline & $\begin{array}{l}\text { The boundary condition is given as: } \\
\mathrm{T}(\mathrm{x}, \mathrm{t})=\mathrm{f}(\mathrm{x}, \mathrm{t}) \text { on a point or a surface } \mathrm{x} \text {. } \\
\lambda \nabla \mathrm{Tn}=\mathrm{b}_{\mathrm{as}}\left(\mathrm{T}_{\mathrm{s}}-\mathrm{T}_{\mathrm{a}}\right) \text { on the surface in contact with the air. } \\
\lambda \frac{\partial \mathrm{T}}{\partial \mathrm{n}}=\mathrm{b}_{\mathrm{gs}}\left(\mathrm{T}_{\mathrm{s}}-\mathrm{T}_{\mathrm{g}}\right) \text { on the surface in contact with a BHE. }\end{array}$ \\
\hline BHE equations & $\begin{array}{l}\text { Inlet pipe: } \rho c_{r} \frac{\partial T_{i}}{\partial t}-\lambda_{r} \frac{\partial^{2} T_{i}}{\partial z^{2}}+\rho c_{r} u \frac{\partial T_{i}}{\partial z}=b_{i g}\left(T_{g}-T_{i}\right) \\
\text { Outlet pipe: } \rho c_{r} \frac{\partial T_{o}}{\partial t}-\lambda_{r} \frac{\partial^{2} T_{o}}{\partial z^{2}}+\rho c_{r} u \frac{\partial T_{o}}{\partial z}=b_{o g}\left(T_{g}-T_{o}\right) \\
\text { Grout: } \rho c_{g} \frac{\partial T_{g}}{\partial t}-\lambda_{g} \frac{\partial^{2} T_{g}}{\partial z^{2}}=b_{i g}\left(T_{i}-T_{g}\right)+b_{o g}\left(T_{o}-T_{g}\right)+b_{g s}\left(T_{s}-T_{g}\right)\end{array}$ \\
\hline \multirow[t]{2}{*}{ BHE boundary and initial conditions } & $\begin{array}{l}\text { Initially, at } \mathrm{t}=0 \text {, the temperature in the BHE is equal to the steady-state temperature } \\
\text { in the soil: } \\
\mathrm{T}_{\mathrm{i}}(\mathrm{z}, 0)=\mathrm{T}_{\mathrm{o}}(\mathrm{z}, 0)=\mathrm{T}_{\mathrm{g}}(\mathrm{z}, 0)=\mathrm{T}_{\mathrm{s}}(\mathrm{z}, 0)\end{array}$ \\
\hline & $\begin{array}{l}\text { The first boundary conditions: } \mathrm{T}_{\mathrm{i}}(\mathrm{O}, \mathrm{t})=\mathrm{T}_{\mathrm{in}}(\mathrm{t}) \\
\text { The second boundary conditions: } \frac{\partial \mathrm{T}_{\mathrm{o}}(0, \mathrm{t})}{\partial \mathrm{z}}=0\end{array}$ \\
\hline
\end{tabular}

These heat transfer partial differential equations are discretized based on the weighted cell-cantered-upwind second-order scheme.

The velocity and temperature are discretized on a staggered grid, requiring that the velocity vector is situated at its surface, 
whereas the temperature is situated at the cell centre as indicated in Fig. $17[151,152]$. The FVM model is validated by the measured data and analytical solution, where it is revealed that the approach is very precise even for a very short time.

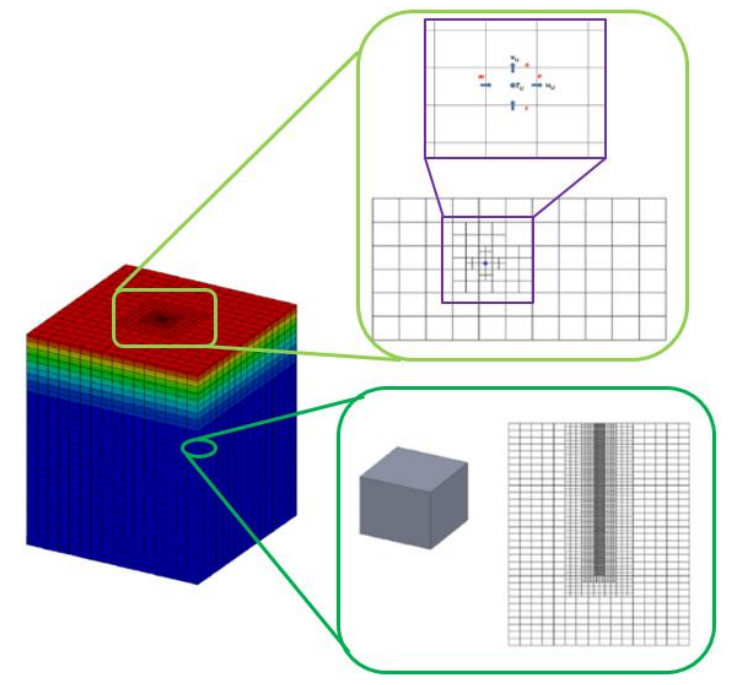

Fig.17. The discretization grid based on FVM [151, 152].

\subsection{D TRCM model}

\subsubsection{D TRCM model based on the FDM}

Diersch and Bauter $[154,155]$ proposed a series of 2D TRCM models for various BHE configurations, but the 2D models cannot correctly represent the vertical heat transfer within and nearby the BHE, soil temperature variation, and transient working fluid flow within the tubes as well as thermal short-circuiting between two legs of the tube. To solve these problems, Bauer et al. [112] proposed a 3D transient heat and mass transfer BHE model with satisfactory accuracy coupled with minimum computational demand.

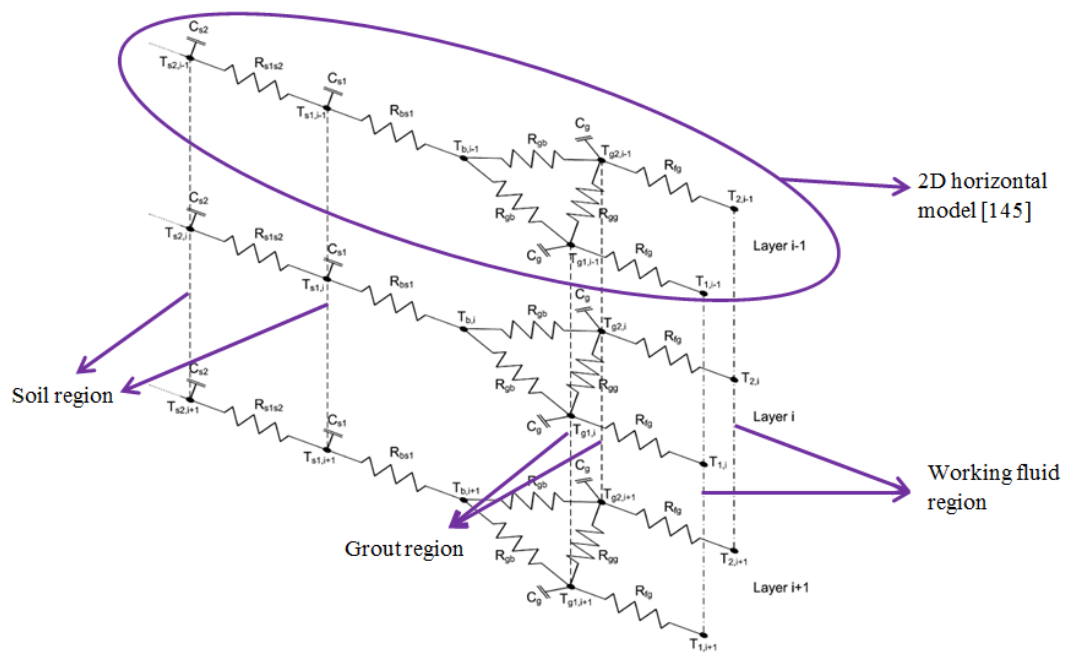

Fig.18. 3D TRCM model in the vertical direction [112].

Fig.18 displays a section of the model where several 2D horizontal models are linked to a 3D model in the vertical direction. Correspondingly, the BHE heat capacities and thermal resistances are summarised in Table 6. The proposed models have been 
verified through ANSYS model for the outlet fluid temperature as presented in Fig.19. It is found that the transient model is in very good agreement with the ANSYS model and the maximum outlet fluid temperature error is $7.1 \%$ for a short period.

Table 6 TRCM heat transfer equations [112].

\section{Description}

\section{Equations}

Heat transfer within the soil: the process of soil heat transfer is regarded as transient state.

$$
\frac{\partial \mathrm{T}_{\mathrm{s} 1, \mathrm{i}}}{\partial \mathrm{t}}+\frac{1}{\mathrm{C}_{\mathrm{s} 1}} \cdot\left[\frac{\mathrm{T}_{\mathrm{s} 1, \mathrm{i}}-\mathrm{T}_{\mathrm{s} 2 \mathrm{i}}}{\mathrm{R}_{\mathrm{sls} 2}}+\frac{\mathrm{T}_{\mathrm{sl}, \mathrm{i}}-\mathrm{T}_{\mathrm{b}, \mathrm{i}}}{\mathrm{R}_{\mathrm{bs} 1}}+\frac{2 \cdot \mathrm{T}_{\mathrm{sl}, \mathrm{i}}-\mathrm{T}_{\mathrm{sl}, \mathrm{i}-1}-\mathrm{T}_{\mathrm{s} 1 \mathrm{i}+\mathrm{i}}}{\mathrm{dz}^{2} \cdot \mathrm{k}_{\mathrm{soil}}^{-1} \cdot \mathrm{A}_{\mathrm{s} 1}^{-1}}\right]=0
$$

$\frac{\partial \mathrm{T}_{\mathrm{sj}, \mathrm{i}}}{\partial \mathrm{t}}+\frac{1}{\mathrm{C}_{\mathrm{sj}}} \cdot\left[\frac{\mathrm{T}_{\mathrm{s}, \mathrm{i}}-\mathrm{T}_{\mathrm{s}(\mathrm{j}+1), \mathrm{i}}}{\mathrm{R}_{\mathrm{sj}(\mathrm{j}+1)}}+\frac{\mathrm{T}_{\mathrm{sj}, \mathrm{i}}-\mathrm{T}_{\mathrm{s}(\mathrm{j}-1) \mathrm{i}}}{\mathrm{R}_{\mathrm{s}(\mathrm{j}-1) \mathrm{sj}}}+\frac{2 \cdot \mathrm{T}_{\mathrm{sj}, \mathrm{i}}-\mathrm{T}_{\mathrm{s}, \mathrm{i}-1}-\mathrm{T}_{\mathrm{sj}, \mathrm{i}+1}}{\mathrm{dz}^{2} \cdot \mathrm{k}_{\mathrm{soil}}^{-1} \cdot \mathrm{A}_{\mathrm{sj}}^{-1}}\right]=0$

$$
\frac{\partial \mathrm{T}_{\mathrm{g} 1, \mathrm{i}}}{\partial \mathrm{t}}+\frac{1}{\mathrm{C}_{\mathrm{g}}} \cdot\left[\frac{\mathrm{T}_{\mathrm{gl}, \mathrm{i}}-\mathrm{T}_{\mathrm{g} 2, \mathrm{i}}}{\mathrm{R}_{\mathrm{gg}}}+\frac{\mathrm{T}_{\mathrm{gl}, \mathrm{i}}-\mathrm{T}_{\mathrm{b}, \mathrm{i}}}{\mathrm{R}_{\mathrm{gb}}}+\frac{\mathrm{T}_{\mathrm{gl}, \mathrm{i}}-\mathrm{T}_{1, \mathrm{i}}}{\mathrm{R}_{\mathrm{fg}}}+\frac{2 \cdot \mathrm{T}_{\mathrm{gl}, \mathrm{i}}-\mathrm{T}_{\mathrm{gl}, \mathrm{i}-1}-\mathrm{T}_{\mathrm{gl}, \mathrm{i}+1}}{\mathrm{dz}^{2} \cdot \mathrm{k}_{\mathrm{grout}}^{-1} \cdot \mathrm{A}_{\mathrm{gl}}^{-1}}\right]=0
$$

Heat transfer within the grout:

$$
\frac{\frac{\partial \mathrm{T}_{\mathrm{g} 2, \mathrm{i}}}{\partial \mathrm{t}}+\frac{1}{\mathrm{C}_{\mathrm{g}}} \cdot\left[\frac{\mathrm{T}_{\mathrm{g} 2, \mathrm{i}}-\mathrm{T}_{\mathrm{g} 1, \mathrm{i}}}{\mathrm{R}_{\mathrm{gg}}}+\frac{\mathrm{T}_{\mathrm{g} 2, \mathrm{i}}-\mathrm{T}_{\mathrm{b}, \mathrm{i}}}{\mathrm{R}_{\mathrm{gb}}}+\frac{\mathrm{T}_{\mathrm{g} 2, \mathrm{i}}-\mathrm{T}_{2, \mathrm{i}}}{\mathrm{R}_{\mathrm{fg}}}+\frac{2 \cdot \mathrm{T}_{\mathrm{g} 2, \mathrm{i}}-\mathrm{T}_{\mathrm{g} 2, \mathrm{i}-1}-\mathrm{T}_{\mathrm{g} 2, \mathrm{i}+1}}{\mathrm{dz}^{2} \cdot \mathrm{k}_{\mathrm{grout}}^{-1} \cdot \mathrm{A}_{\mathrm{g} 2}^{-1}}\right]=0}{\frac{\partial \mathrm{T}_{1, \mathrm{i}}}{\partial \mathrm{t}}+\frac{1}{\mathrm{C}_{\text {fluid }}} \cdot\left[\frac{\mathrm{T}_{1, \mathrm{i}}-\mathrm{T}_{\mathrm{g} 1, \mathrm{i}}}{\mathrm{R}_{\mathrm{fg}}}+\frac{2 \cdot \mathrm{T}_{1, \mathrm{i}}-\mathrm{T}_{1, \mathrm{i}-1}-\mathrm{T}_{1, \mathrm{i}+1}}{\mathrm{dz}^{2} \cdot \mathrm{k}_{\mathrm{fluid}}^{-1} \cdot \mathrm{A}_{\mathrm{f} 1}^{-1}}+\frac{\mathrm{m}_{\mathrm{fluid}} \cdot \mathrm{c}_{\mathrm{p}, \text { fluid }}}{\mathrm{dz}}\left(\mathrm{T}_{1, \mathrm{i}}-\mathrm{T}_{1, \mathrm{i}-1}\right)\right]=0}
$$

Heat transfer within the tubes:

$$
\frac{\partial \mathrm{T}_{2, \mathrm{i}}}{\partial \mathrm{t}}+\frac{1}{\mathrm{C}_{\text {fluid }}} \cdot\left[\frac{\mathrm{T}_{2, \mathrm{i}}-\mathrm{T}_{\mathrm{g} 2, \mathrm{i}}}{\mathrm{R}_{\mathrm{fg}}}+\frac{2 \cdot \mathrm{T}_{2, \mathrm{i}}-\mathrm{T}_{2, \mathrm{i}-1}-\mathrm{T}_{2, \mathrm{i}+1}}{\mathrm{dz}^{2} \cdot \mathrm{k}_{\text {fluid }}^{-1} \cdot \mathrm{A}_{\mathrm{f} 2}^{-1}}+\frac{\mathrm{m}_{\text {fluid }} \cdot \mathrm{c}_{\mathrm{p}, \text { fluid }}}{\mathrm{dz}}\left(\mathrm{T}_{2, \mathrm{i}}-\mathrm{T}_{2, \mathrm{i}+1}\right)\right]=0
$$

Heat transfer within the working fluid:

$$
\begin{aligned}
& \frac{\mathrm{T}_{1, \mathrm{i}}-\mathrm{T}_{\mathrm{g} 1, \mathrm{i}}}{\mathrm{R}_{\mathrm{fg}}}+\frac{2 \cdot \mathrm{T}_{1, \mathrm{i}}-\mathrm{T}_{1, \mathrm{i}-1}-\mathrm{T}_{1, \mathrm{i}+1}}{\mathrm{dz}^{2} \cdot \mathrm{k}_{\mathrm{fluid}}^{-1} \cdot \mathrm{A}_{\mathrm{f} 1}^{-1}}+\frac{\mathrm{m}_{\text {fluid }} \cdot \mathrm{c}_{\mathrm{p}, \text { fluid }}}{\mathrm{dz}}\left(\mathrm{T}_{1, \mathrm{i}}-\mathrm{T}_{1, \mathrm{i}-1}\right)=0 \\
& \frac{\mathrm{T}_{\mathrm{g} 2, \mathrm{i}}-\mathrm{T}_{\mathrm{g} 1, \mathrm{i}}}{\mathrm{R}_{\mathrm{gg}}}+\frac{\mathrm{T}_{\mathrm{g} 2, \mathrm{i}}-\mathrm{T}_{\mathrm{b}, \mathrm{i}}}{\mathrm{R}_{\mathrm{gb}}}+\frac{\mathrm{T}_{\mathrm{g} 2, \mathrm{i}}-\mathrm{T}_{2, \mathrm{i}}}{\mathrm{R}_{\mathrm{fg}}}+\frac{2 \cdot \mathrm{T}_{\mathrm{g} 2, \mathrm{i}}-\mathrm{T}_{\mathrm{g} 2, \mathrm{i}-1}-\mathrm{T}_{\mathrm{g} 2, \mathrm{i}+1}}{\mathrm{dz}^{2} \cdot \mathrm{k}_{\mathrm{grout}}^{-1} \cdot \mathrm{A}_{\mathrm{g} 2}^{-1}}=0
\end{aligned}
$$
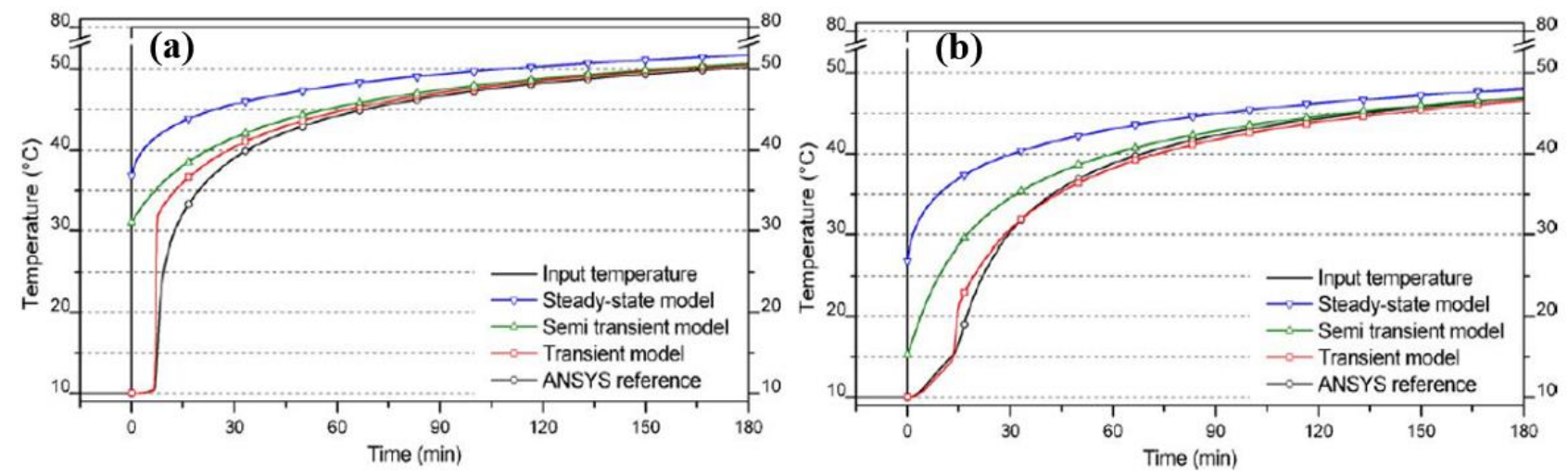

Fig.19. The outlet fluid temperature variation: (a) single; (b) double U-tube BHE [112].

\subsubsection{TRCM 3D model based on FEM}

Diersch et al. [154, 155] proposed a numerical approach of the 3D TRCM model which is implemented by an extensively nonsequential coupling method for the BHE discretization based on the FEM. Two types of the BHE configurations are presented in Fig.20 for the single- and double- pipes whereas the centred (CXC) inlet and coaxial pipes with annular (CXA) configurations are depicted in Fig.21. 

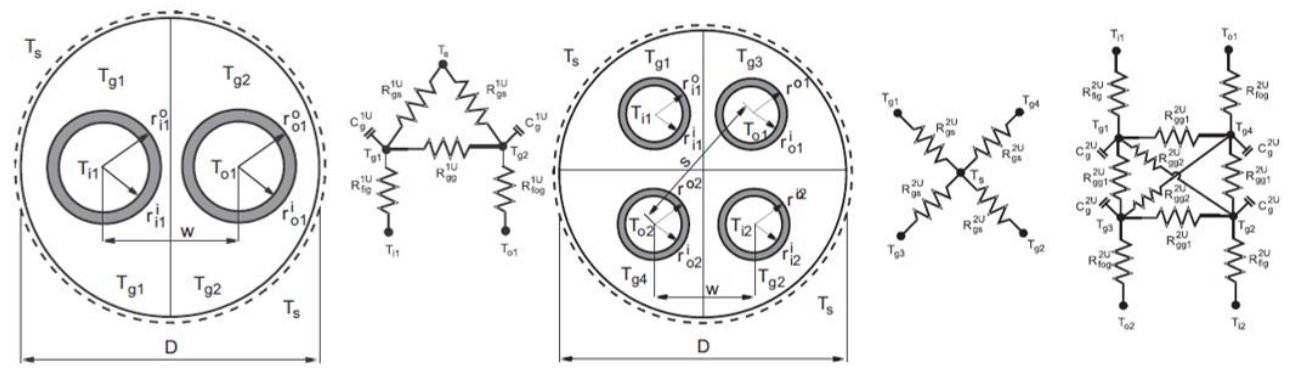

Fig.20. The schematic of internal pipe-grout thermal resistance connections of a 1U BHE and 2U BHE [154].
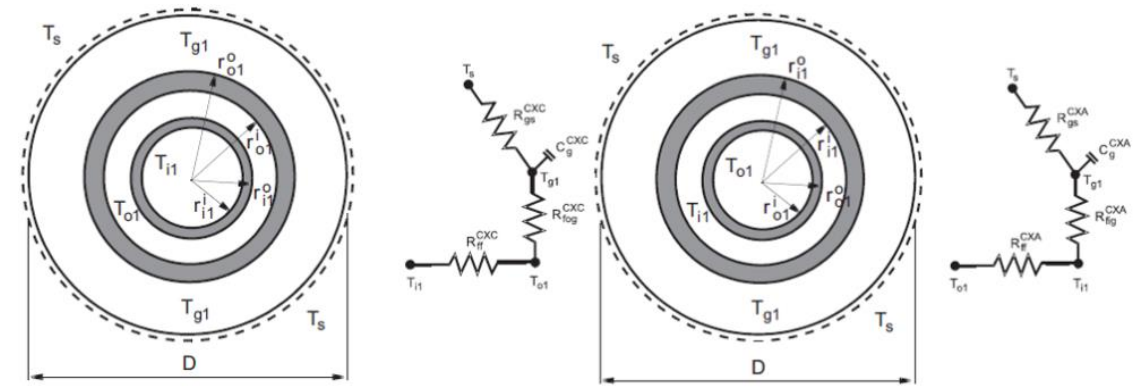

Fig.21. The schematic of internal pipe-grout thermal resistance connections of a CXC BHE and CAX BHE [154].

These governing equations are discretized based on the FEM, which are verified by FEFLOW software. The numerical simulation results versus theoretical analysis data for four types of the BHE arrangements are presented in Fig.22.
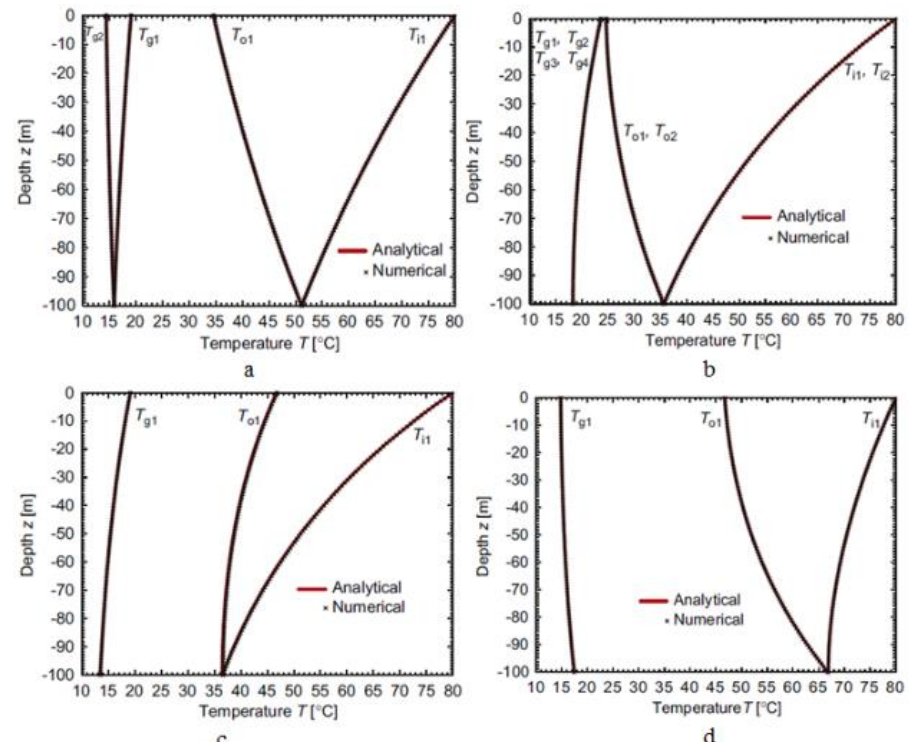

Fig.22. The schematic of temperature variations on four different types of BHEs [155].

As evidenced, all cases agree with each other. This comes with some advantages: (1) an accurate and practical applicability of the BHE transient heat transfer model; (2) a much greater flexibility in the arrangement of U-shape loop; (3) a precise heat flow along the U-tube loop in parallel or series arrangement. 


\subsubsection{Improved MTRCM model}

Pasquier and Marcotte [160] presented a quasi-3D TRCM model by combining the previous TRCM [131] and the spectral approach to simulate the working fluid temperature variation with time. The model is improved by considering the vertical fluid advection in the pipes as shown in Fig.23. In order to evaluate the accuracy of the modified approach, three comparison scenarios are analysed. It is found that the model can provide the results with a reduced computational time (in a few seconds) with deviations which are less than the measurement uncertainty.

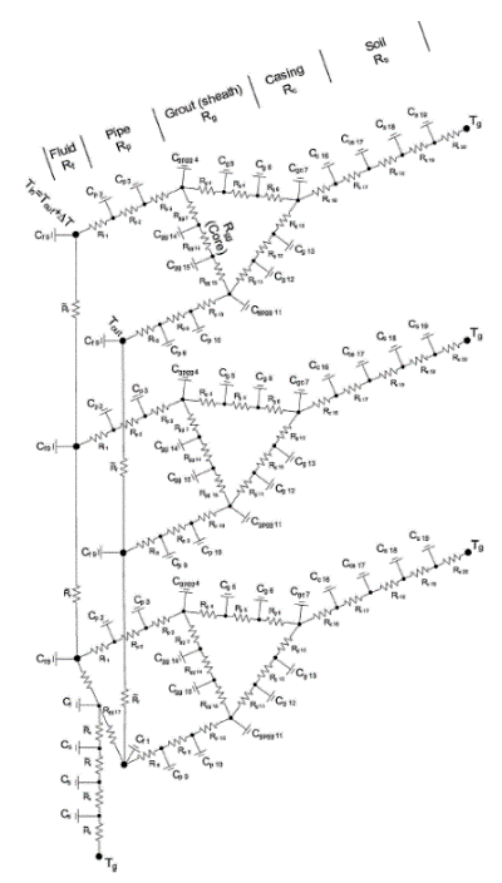

Fig.23. An example of network for 3 layers [154].

\subsubsection{Simplified 3D TRCM (STRCM) model}

Minaei and Maerefat [133] developed a 3D equivalent thermal network STRCM model based on their 2D STRCM model as shown in Fig.24. The cylinder source model (ICS) is adopted to analyse the soil heat transfer nearby the BHE. The fluid outlet temperatures from the 3D STRCM are compared with the test data as presented in Fig.25 (a) for the first one hour and Fig.25 (b) for 50 hours. It is found that the model results and experimental data match each other. Therefore, the simplified 3D STRCM model can accurately predict the fluid outlet temperature. 


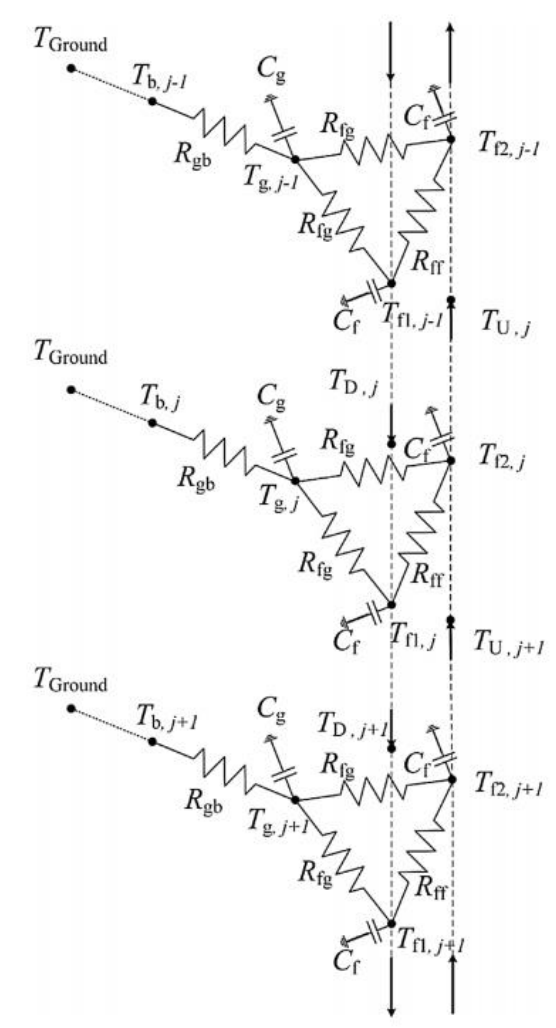

Fig.24. 3D STRCM network [133].
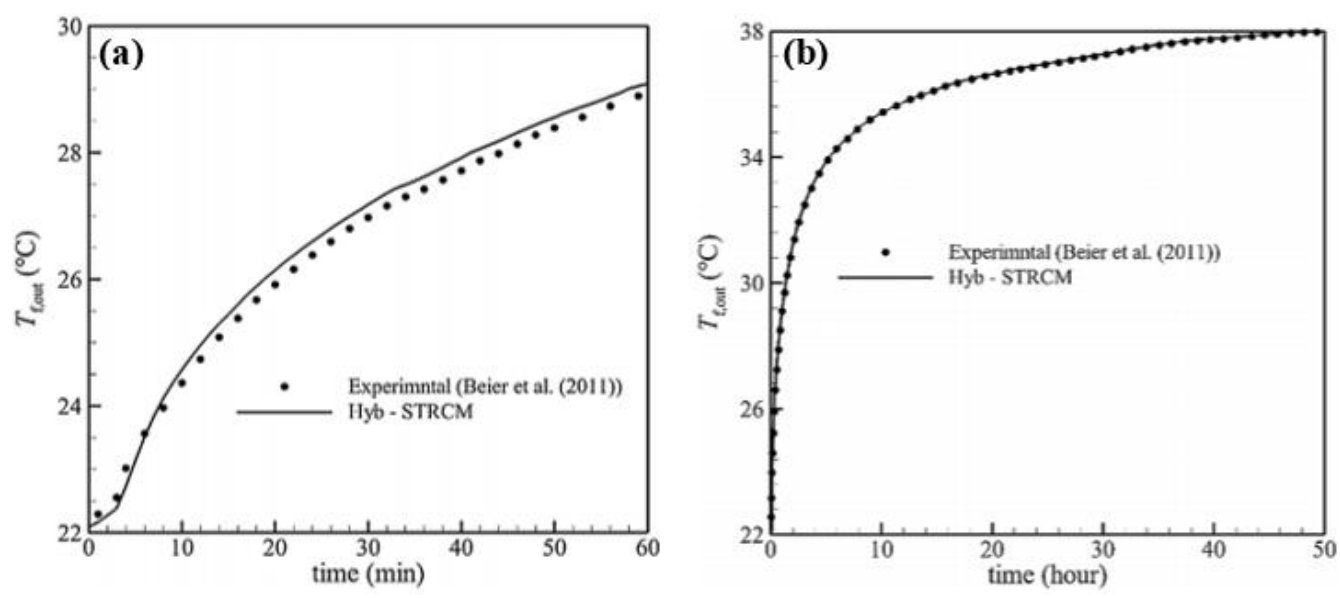

Fig.25. The outlet fluid temperature of the STRCM and experimental data for different operation time: (a) for first one hour; (b) for 50 hours [133].

\subsection{Multiple Degrees of Freedom (MDF) model}

Wołoszyn and Goła's [157-159] presented a 3D numerical model with multiple degrees of freedom (MDF) to calculate the thermal energy flow and the heat transfer within a single vertical BHE based on the FEM. This model significantly decreases the numerical calculation time. To precisely replicate the procedure of the heat exchange within a BHE, a single BHE model has been evaluated by approximating the grout to three nodes and dividing the region into three parts as shown in Fig.26. The mathematical description is given in Table 7. 
Table 7 The mathematic description of MDF [157-159].

\begin{tabular}{|c|c|}
\hline Description & Equations \\
\hline Soil region: & $\frac{\partial}{\partial \mathrm{x}}\left(\frac{\partial \mathrm{T}_{\mathrm{s}}}{\partial \mathrm{x}}\right)+\frac{\partial}{\partial \mathrm{y}}\left(\frac{\partial \mathrm{T}_{\mathrm{s}}}{\partial \mathrm{y}}\right)+\frac{\partial}{\partial \mathrm{z}}\left(\frac{\partial \mathrm{T}_{\mathrm{s}}}{\partial \mathrm{z}}\right)=\frac{\mathrm{c}_{\mathrm{s}} \cdot \rho_{\mathrm{s}}}{\lambda_{\mathrm{s}}} \frac{\partial \mathrm{T}_{\mathrm{s}}}{\partial \mathrm{t}}$ \\
\hline Pipe and fluid regions: & $\begin{array}{l}\frac{\partial \mathrm{T}_{\mathrm{s}}}{\partial \mathrm{t}} \rho_{\mathrm{f}} \mathrm{c}_{\mathrm{f}} \frac{\partial \mathrm{T}_{\mathrm{i}}}{\partial \mathrm{t}}+\rho_{\mathrm{f}} \mathrm{c}_{\mathrm{f}} \mathrm{u}_{\mathrm{i}} \frac{\partial \mathrm{T}_{\mathrm{i}}}{\partial \mathrm{z}}-\lambda_{\mathrm{f}} \frac{\partial^{2} \mathrm{~T}_{\mathrm{i}}}{\partial \mathrm{z}^{2}}-\mathrm{b}_{\mathrm{ig} 1}\left(\mathrm{~T}_{\mathrm{g} 1}-\mathrm{T}_{\mathrm{i}}\right)-\mathrm{b}_{\mathrm{ig} 3}\left(\mathrm{~T}_{\mathrm{g} 3}-\mathrm{T}_{\mathrm{i}}\right)=0 ; \\
\rho_{\mathrm{g}} \mathrm{c}_{\mathrm{g}} \frac{\partial \mathrm{T}_{\mathrm{g} 2}}{\partial \mathrm{t}}-\lambda_{\mathrm{g}} \frac{\partial^{2} \mathrm{~T}_{\mathrm{g} 2}}{\partial \mathrm{z}^{2}}-\mathrm{b}_{\mathrm{og} 2}\left(\mathrm{~T}_{\mathrm{o}}-\mathrm{T}_{\mathrm{g} 2}\right)-\mathrm{b}_{\mathrm{g} 2 \mathrm{~g} 1}\left(\mathrm{~T}_{\mathrm{g} 1}-\mathrm{T}_{\mathrm{g} 2}\right)-\mathrm{b}_{\mathrm{g} 2 \mathrm{~g} 3}\left(\mathrm{~T}_{\mathrm{g} 3}-\mathrm{T}_{\mathrm{g} 2}\right)=0 ;\end{array}$ \\
\hline
\end{tabular}

The results obtained from the MDF model for temperature variations are compared to the Diersch's model and quasi-3D ANSYS model data. It is found that slight errors are obtained for the MDF and Diersch models with about $5.5 \%$ and $7.5 \%$, respectively. The merit of the MDF approach over the Oppelt et al. [110] method is that the MDF utilizes the FEM with quadratic shape function which enhances the computational performances. Alternatively, the superiority of the MDF method over the Diersch et al. $[154,155]$ approach is that the MDF model separates the grout domain into three regions. As a result, it considers the effect of temperature difference between two legs of a U-tube.

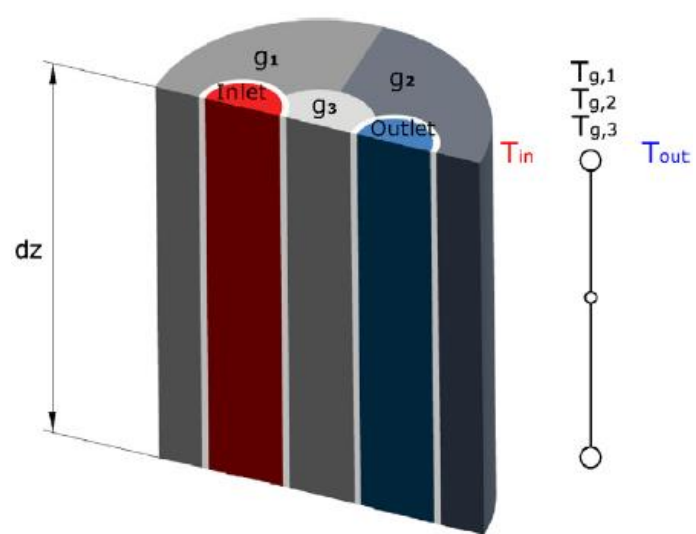

Fig.26. The diagram of BHE with subarea [157].

In further development, Wołoszyn and Gołas [158] applied the MDF approach to investigate the influences of various parameters on the BHE behaviour. This modified MDF model has been analysed by using the ANSYS software package [159]. The results indicate that the thermal conductivities of the grout and the soil have significant effects on the BHE efficiency. It is also confirmed that the presented approach can significantly decrease the computational time and estimate the impact of the selected parameter 
on the BHE efficiency for the short-term operation. The model has been identified as a tool for the long-term performance prediction, system optimisation and calculation of the effective soil thermal conductivity. In this study, a significant reduction of CPU time is noted with numerical results proved to be in good agreement with the measurement data, implying that the MDF model is suitable for application in engineering practice.

\subsection{Summary of 3D models}

By taking into account the transient working fluid within the pipe and its thermal capacity, the 3D models could be more precise and realistic than the 2D models. For a complete analysis of the BHE, merely 3D models could be used because the heat transfer in the ground layers and the working fluid flow state as well as the boundary conditions are taken into account. Therefore, several 3D discretised methods have been developed to provide a more precise and comprehensive analysis for the BHEs as illustrated in Table 8. From the above reviews in this section, the 3D models have been indicated to be more advantageous in that the dynamic working fluid along the pipe can be characterized accurately with the consideration of the temperature variation within the BHE depth. Also, various layers of the soil can be explicitly represented and the weather data can be utilized as the boundary condition at the soil surface, in addition to allowing the consideration of the soil region underneath the BHE. Furthermore, the heat transfer at the bottom of the BHE can be evaluated. Lastly, the thermal interferences among multiple BHEs with different configurations can be investigated. In addition to the above merits, the 3D models are also utilized to analyse the effects of the undisturbed soil temperature, the thermal short-circuiting between two legs of the U-tube, the boundary conditions at the top and bottom as well as the effect of the groundwater movement. However, the main drawback of the 3D discretized models is the long computation time because of the multiple components needed for proper discretisation. 
Table 8 The comparison of 3D models

\begin{tabular}{|c|c|c|c|c|c|c|c|}
\hline \multicolumn{8}{|c|}{ 3D models } \\
\hline \multirow{2}{*}{\multicolumn{2}{|c|}{ Model Name }} & \multirow[t]{2}{*}{ Ref. } & \multirow[t]{2}{*}{ Assumption conditions } & \multirow[t]{2}{*}{ Boundary conditions } & \multicolumn{3}{|c|}{ Special findings } \\
\hline & & & & & Method used & Error analysis & Scope of Applications \\
\hline \multicolumn{2}{|c|}{ Zeng's model } & $\begin{array}{c}\text { Zeng et al. } \\
\text { [71] }\end{array}$ & $\begin{array}{l}\text { 1) The soil is assumed as a uniform } \\
\text { semi-infinite medium and thermal } \\
\text { physical properties cannot change } \\
\text { with time; 2) The medium is } \\
\text { assumed as a uniform initial } \\
\text { temperature; 3) The radial } \\
\text { dimension of the BHE is ignored; 4) } \\
\text { The heat transfer rate per unit length } \\
\text { is uniform and constant. }\end{array}$ & $\begin{array}{l}\text { 1) The boundary condition of medium: the soil surface } \\
\text { maintains a constant value that is the similar as its initial } \\
\text { temperature; 2) The temperature is chosen as its } \\
\text { representative temperature at the middle of the depth. }\end{array}$ & $\begin{array}{l}\text { 1) Based on the FEM; 2) The } \\
\text { heat transfer model is } \\
\text { divided into two parts: inside } \\
\text { and outside BHE. }\end{array}$ & $\begin{array}{l}\text { The comparison is a good } \\
\text { agreement between Kelvin's } \\
\text { model and the finite line } \\
\text { source method. }\end{array}$ & $\begin{array}{l}\text { 1) To analyze the thermal } \\
\text { resistance without the } \\
\text { BHE for long term steps; } \\
\text { 2) To analyze the thermal } \\
\text { short-circuiting between } \\
\text { two legs of U-tube pipe; } \\
\text { 3) To contribute to } \\
\text { develop for engineering } \\
\text { design and thermal } \\
\text { analysis of vertical BHE. }\end{array}$ \\
\hline \multirow[t]{2}{*}{$\begin{array}{l}\text { R Al- } \\
\text { Khoury } \\
\text { model }\end{array}$} & $\begin{array}{l}\text { 3D steady } \\
\text { state } \\
\text { model }\end{array}$ & $\begin{array}{l}\text { Al-Khoury and } \\
\text { Bonnier [99] }\end{array}$ & $\begin{array}{l}\text { 1) Heat transfer in the BHE is } \\
\text { assumed as steady state; 2) The heat } \\
\text { pipe region is assumed as 1D model. }\end{array}$ & $\begin{array}{l}\text { 1) For heat flow field within soil layer: } \\
\lambda_{\mathrm{x}} \frac{\partial \mathrm{T}_{\mathrm{s}}}{\partial \mathrm{x}} \mathrm{n}_{\mathrm{x}}+\lambda_{\mathrm{y}} \frac{\partial \mathrm{T}_{\mathrm{s}}}{\partial \mathrm{y}} \mathrm{n}_{\mathrm{y}}+\lambda_{\mathrm{z}} \frac{\partial \mathrm{T}_{\mathrm{s}}}{\partial \mathrm{z}} \mathrm{n}_{\mathrm{z}}+\mathrm{h}=0 \\
\lambda_{\mathrm{x}} \frac{\partial \mathrm{T}_{\mathrm{s}}}{\partial \mathrm{x}} \mathrm{n}_{\mathrm{x}}+\lambda_{\mathrm{y}} \frac{\partial \mathrm{T}_{\mathrm{s}}}{\partial \mathrm{y}} \mathrm{n}_{\mathrm{y}}+\lambda_{\mathrm{z}} \frac{\partial \mathrm{T}_{\mathrm{s}}}{\partial \mathrm{z}} \mathrm{n}_{\mathrm{z}}+\mathrm{C}_{\mathrm{as}}\left(\mathrm{T}_{\mathrm{s}}-\mathrm{T}_{\mathrm{a}}\right)=0 \\
\lambda_{\mathrm{z}} \frac{\partial \mathrm{T}_{\mathrm{s}}}{\partial \mathrm{z}} \mathrm{n}_{\mathrm{z}}+\mathrm{b}_{\mathrm{gs}}\left(\mathrm{T}_{\mathrm{s}}-\mathrm{T}_{\mathrm{g}}\right)=0 \\
\text { 2) The grout boundary conditions: } \\
-\lambda_{\mathrm{g}} \frac{\partial \mathrm{T}_{\mathrm{g}}}{\partial \mathrm{n}}=\mathrm{b}_{\mathrm{sg}}\left(\mathrm{T}_{\mathrm{g}}-\mathrm{T}_{\mathrm{s}}\right)\end{array}$ & $\begin{array}{l}\text { 1) FEM---Petrov-Galerkin } \\
\text { method; 2) Based on the } \\
\text { variation method and the } \\
\text { weighted residuals approach. }\end{array}$ & $\begin{array}{l}\text { The error along the pipe is } \\
\text { less than } 1.5 \% \text { between } \\
\text { proposed model and } \\
\text { analytical solutions. }\end{array}$ & $\begin{array}{l}\text { 1) This model is able to } \\
\text { analyse 3D steady-state } \\
\text { heat transfer model; 2) } \\
\text { This model is able to } \\
\text { solve the inherit aspect } \\
\text { ratio issue in BHE } \\
\text { system. }\end{array}$ \\
\hline & $\begin{array}{l}3 \mathrm{D} \\
\text { transient } \\
\text { model }\end{array}$ & $\begin{array}{c}\text { Al-Khoury and } \\
\text { Bonnier [100] }\end{array}$ & $\begin{array}{l}\text { 1) The groundwater flow is regarded } \\
\text { as in fully saturated porous soils in } \\
\text { deep aquifers; 2) The heat pipe } \\
\text { region is assumed as } 1 \mathrm{D} \text { model. }\end{array}$ & $\begin{array}{l}\text { The boundary conditions: } \\
\lambda_{\mathrm{x}} \frac{\partial \mathrm{T}_{\mathrm{s}}}{\partial \mathrm{x}} \mathrm{n}_{\mathrm{x}}+\lambda_{\mathrm{y}} \frac{\partial \mathrm{T}_{\mathrm{s}}}{\partial \mathrm{y}} \mathrm{n}_{\mathrm{y}}+\lambda_{\mathrm{z}} \frac{\partial \mathrm{T}_{\mathrm{s}}}{\partial \mathrm{z}} \mathrm{n}_{\mathrm{z}}+\mathrm{C}_{\mathrm{as}}\left(\mathrm{T}_{\mathrm{s}}-\mathrm{T}_{\mathrm{a}}\right)=0 \\
\lambda_{\mathrm{z}} \frac{\partial \mathrm{T}_{\mathrm{s}}}{\partial \mathrm{z}} \mathrm{n}_{\mathrm{z}}+\mathrm{b}_{\mathrm{gs}}\left(\mathrm{T}_{\mathrm{s}}-\mathrm{T}_{\mathrm{g}}\right)=0 \\
\mathrm{~T}=\mathrm{T}(\mathrm{z}, \mathrm{t}) ;-\lambda_{\mathrm{g}} \frac{\partial \mathrm{T}_{\mathrm{g}}}{\partial \mathrm{n}}=\mathrm{b}_{\mathrm{sg}}\left(\mathrm{T}_{\mathrm{g}}-\mathrm{T}_{\mathrm{s}}\right)\end{array}$ & $\begin{array}{l}\text { 1) FEM---Petrov-Galerkin } \\
\text { method; 2) The weighted } \\
\text { residuals approach. }\end{array}$ & $\begin{array}{l}\text { The maximum error is } \\
0.5{ }^{\circ} \mathrm{C} \text { between } \\
\text { model and anaposed } \\
\text { solutions. }\end{array}$ & $\begin{array}{l}\text { 1) This approach is able } \\
\text { to analyse a pseudo } 3 \mathrm{D} \\
\text { heat flow in a U-tube } \\
\text { loop BHE using (1D) } \\
\text { FEM; 2) This approach is } \\
\text { utilized for resolving the } \\
\text { resulting non-linear } \\
\text { system of formulations. }\end{array}$ \\
\hline \multicolumn{2}{|c|}{ M. Nabi FVM model } & $\begin{array}{l}\text { Nabi and Al- } \\
\text { Khoury [151, } \\
\text { 152] }\end{array}$ & $\begin{array}{l}\text { 1) For the fluid flow in the soil, at } \\
\mathrm{t}=0 \text {, the hydrostatic head is assumed } \\
\text { as } \varphi(x, y, z, 0)=\varphi_{0}(x, y, z) \\
\text { 2) For the heat flow within soil } \\
\text { volume: at } t=0 \text {, the initial condition } \\
\text { is assumed as the steady-state } \\
\text { condition: } \\
T(x, y, z, 0)=f(x, y, z) \\
\text { 3) For the } B H E \text { region, at } t=0 \text {, } \\
T_{i}(z, 0)=T_{0}(z, 0)=T_{g}(z, 0)=T_{s}(z, 0)\end{array}$ & $\begin{array}{l}\text { 1) For groundwater flow within soil volume: } \\
\varphi(\mathrm{x}=0, \mathrm{y}, \mathrm{z})=\varphi_{1} \text {, on } \mathrm{x}=0 \text { surface; } \\
\varphi(\mathrm{x}=\mathrm{L}, \mathrm{y}, \mathrm{z})=\varphi_{2} \text { on } \mathrm{x}=\mathrm{L} \text { surface; } \\
\mathrm{k} \nabla \varphi \mathrm{n}=\mathrm{J} \text {, on any of the boundary surfaces; } \\
\text { 2) For the heat flow within soil volume: } \\
\mathrm{T}(\mathrm{x}, \mathrm{t})=\mathrm{f}(\mathrm{x}, \mathrm{t}) \text {, on a point or a surface } \mathrm{x} \text {; } \\
\lambda \nabla \mathrm{T}_{\mathrm{n}}=\mathrm{b}_{\mathrm{as}}\left(\mathrm{T}_{\mathrm{s}}-\mathrm{T}_{\mathrm{a}}\right) \text {, on the surface in contact with the } \\
\text { air; } \\
\lambda \frac{\partial \mathrm{T}}{\partial \mathrm{n}}=\mathrm{b}_{\mathrm{gs}}\left(\mathrm{T}_{\mathrm{s}}-\mathrm{T}_{\mathrm{g}}\right) \text {, on the surface in contact with a } \\
\text { BHE; } \\
\text { 3) For the BHE: } \\
\text { The first boundary condition: } \mathrm{T}_{\mathrm{i}}(0, \mathrm{t})=\mathrm{T}_{\mathrm{in}}(\mathrm{t})\end{array}$ & Based on FVM & $\begin{array}{l}\text { The results are in the order } \\
\text { of } \pm 1{ }^{\circ} \mathrm{C} \text { from those gained } \\
\text { from the field constituting } \\
\text { an error of less than } 4 \% \text { on } \\
\text { average. }\end{array}$ & $\begin{array}{l}\text { The mode is used to } \\
\text { simulate 3D heat transfer } \\
\text { procedures for multiple } \\
\text { BHEs embedded in } \\
\text { different of soil layer. }\end{array}$ \\
\hline
\end{tabular}




\begin{tabular}{|c|c|c|c|c|c|c|c|}
\hline & & & & The second boundary condition: $\frac{\partial T_{0}(0, t)}{\partial z}=0$ & & & \\
\hline \multicolumn{2}{|c|}{ MDF model } & $\begin{array}{l}\text { Wołoszyn and } \\
\text { Gołas [157- } \\
159]\end{array}$ & $\begin{array}{l}\text { 1) A 1D component with multiple } \\
\text { degrees of freedom is assumed in } \\
\text { this model; 2) The inlet-pipe } \\
\text { temperature is known. }\end{array}$ & $\begin{array}{l}\text { 1) The Dirichlet boundary condition: } \\
\mathrm{T}=\mathrm{T}_{\mathrm{i}}(\mathrm{z}, \mathrm{t}) \text { for } \mathrm{z}=0 \text {; } \\
\text { 2) The Neuman boundary condition: } \\
-\lambda_{\mathrm{g}} \frac{\partial \mathrm{T}_{\mathrm{g} 1 \mathrm{~g} 2}}{\partial \mathrm{z}}=\mathrm{b}_{\mathrm{gl} \mathrm{s}, \mathrm{g} 2 \mathrm{~s}}\left(\mathrm{~T}_{\mathrm{g} 1, \mathrm{~g} 2}-\mathrm{T}_{\mathrm{s}}\right)\end{array}$ & $\begin{array}{l}\text { 1) Based on Oppelt's model; } \\
\text { 2) The FEM is applied in } \\
\text { order to discretize these } \\
\text { equations. }\end{array}$ & $\begin{array}{l}\text { The mean error for the entire } \\
\text { simulation do not exceed } \\
5.5 \% \text { for this model. }\end{array}$ & $\begin{array}{l}\text { The model is used to } \\
\text { analyse the effect of } \\
\text { related parameters on the } \\
\text { efficiency of ground } \\
\text { thermal energy storage. }\end{array}$ \\
\hline \multicolumn{2}{|c|}{ Spectral model } & $\begin{array}{l}\text { BniLam and } \\
\text { Al-Khoury } \\
\text { [165] }\end{array}$ & $\begin{array}{l}\text { The temperature within the BHE is } \\
\text { equal to the steady state temperature: } \\
\mathrm{T}_{\mathrm{i}}(\mathrm{z}, 0)=\mathrm{T}_{0}(\mathrm{z}, 0)=\mathrm{T}_{\mathrm{g}}(\mathrm{z}, 0)=\mathrm{T}_{\mathrm{s}}(\mathrm{z}, 0) \\
\mathrm{T}_{\mathrm{i}}(0, \mathrm{t})=\mathrm{T}_{\mathrm{in}}(\mathrm{T}) \\
\mathrm{T}_{\mathrm{i}}(\mathrm{L}, \mathrm{t})=\mathrm{T}_{\mathrm{o}}(\mathrm{L}, \mathrm{t})\end{array}$ & $\begin{array}{l}\text { 1) For a single U-tube BHE: } \\
-\lambda_{\mathrm{g}} \frac{\partial \mathrm{T}_{\mathrm{g}}(\mathrm{z}, \mathrm{t})}{\partial \mathrm{t}} \mathrm{A}_{\mathrm{g}}-\mathrm{b}_{\mathrm{ig}}\left(\mathrm{T}_{\mathrm{g}}-\mathrm{T}_{\mathrm{i}}\right) \Delta \mathrm{S}_{\mathrm{ig}}-\mathrm{b}_{\mathrm{og}}\left(\mathrm{T}_{\mathrm{g}}-\mathrm{T}_{\mathrm{o}}\right) \Delta \mathrm{S}_{\mathrm{og}} \\
=\mathrm{b}_{\mathrm{gs}}\left(\mathrm{T}_{\mathrm{g}}-\mathrm{T}_{\mathrm{s}}\right) \Delta \mathrm{S}_{\mathrm{sg}}\end{array}$ & $\begin{array}{l}\text { Using the Fourier transform } \\
\text { based on the Al-Khoury' } \\
\text { model. }\end{array}$ & $\begin{array}{l}\text { The error is about } 2^{\circ} \mathrm{C} \\
\text { between the spectral model } \\
\text { and van Genuchten model. }\end{array}$ & $\begin{array}{l}\text { 1) This model is used to } \\
\text { estimate unsteady state } \\
\text { heat transfer with friction } \\
\text { heat gain within a single } \\
\text { BHE; 2) To calculate the } \\
\text { coupled partial } \\
\text { differential formulations. }\end{array}$ \\
\hline \multirow{3}{*}{$\begin{array}{l}\text { 3D TRCM } \\
\text { model }\end{array}$} & $\begin{array}{l}\text { Based on } \\
\text { FDM }\end{array}$ & $\begin{array}{l}\text { Bauter et al. } \\
{[129,130]}\end{array}$ & $\begin{array}{l}\text { 1) BHE thermal capacities are } \\
\text { ignored; 2) This horizontal heat } \\
\text { exchange region among these nodes } \\
\text { are ignored. }\end{array}$ & $\begin{array}{l}\text { This boundary conditions: } \\
\mathrm{C}_{\mathrm{j}}=\sum_{\mathrm{k}=1}^{\mathrm{n}_{\mathrm{j}}} \frac{\rho_{\mathrm{k}} \mathrm{c}_{\mathrm{k}} \mathrm{v}_{\mathrm{k}}}{\mathrm{R}_{\mathrm{k}}}, \mathrm{j}=1 \ldots \mathrm{n}\end{array}$ & Based on an explicit FDM. & $\begin{array}{l}\text { The error is less than } 1.5 \% \text { at } \\
\text { any time for the BHE inlet } \\
\text { temperature. }\end{array}$ & $\begin{array}{l}\text { The model is well used } \\
\text { for incorporation into } \\
\text { unsteady state energy } \\
\text { simulation process. }\end{array}$ \\
\hline & $\begin{array}{l}\text { Based on } \\
\text { FEM }\end{array}$ & $\begin{array}{l}\text { DierschJG. et } \\
\text { al. }[154,155]\end{array}$ & $\begin{array}{l}\text { 1) For pipe region, the radial heat } \\
\text { transfer from the pipes is assumed to } \\
\text { direct to the grout regions; 2) For the } \\
\text { grout region, the heat transfer is } \\
\text { assumed to direct to the nearby soil; } \\
\text { 3) Assuming that the heat coupling } \\
\text { only takes place via the grout field. }\end{array}$ & $\begin{array}{l}\text { 1) Thermal boundary conditions: } \\
\text { Dirichlet-type BC: } \mathrm{T}_{\mathrm{s}}(\mathrm{x}, \mathrm{t})=\mathrm{T}_{\mathrm{s}}^{\mathrm{R}}(\mathrm{T}) \\
\text { Neumann-type BC: } \mathrm{q}_{\mathrm{nTs}}(\mathrm{x}, \mathrm{t})=\mathrm{q}_{\mathrm{nTs}}^{\mathrm{R}}(\mathrm{t})=-\left(\Lambda \cdot \nabla \mathrm{T}_{\mathrm{s}}\right) \cdot \mathrm{n} \\
\text { Cauchy-type BC: } \mathrm{q}_{\mathrm{n} T \mathrm{~s}}(\mathrm{x}, \mathrm{t})=-\sum_{\mathrm{i}=1}^{\mathrm{g}} \varphi_{\mathrm{sg}}\left(\mathrm{T}_{\mathrm{gi}}-\mathrm{T}_{\mathrm{s}}\right)\end{array}$ & $\begin{array}{l}\text { Two methods are utilized: } \\
\text { (1) The analytical method } \\
\text { depended on Eskilson's } \\
\text { model; (2) This numerical } \\
\text { approach relied on Al- } \\
\text { Khoury et al.'s model; 3) } \\
\text { These equations are } \\
\text { discretized through FEM. }\end{array}$ & $\begin{array}{l}\text { An error tolerance of } \\
\varphi=10^{-4} \text { is used. }\end{array}$ & 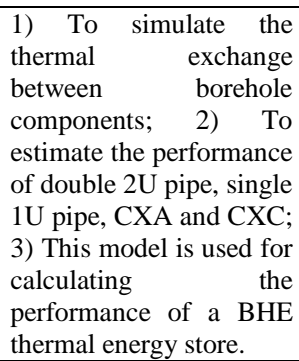 \\
\hline & $\begin{array}{c}\text { 3D } \\
\text { MTRCM } \\
\text { model }\end{array}$ & $\begin{array}{l}\text { Pasquier and } \\
\text { Marcotte [160] }\end{array}$ & $\begin{array}{l}\text { 1) To find the heat flux } q_{1} \text { and } q_{2} \text {, } \\
\text { assuming that two pipes kept at } \\
\text { constant temperatures } T_{1} \text { and } T_{2} \\
\text { under a steady-state; 2) Sub- } \\
\text { capacities are assumed in at each } \\
\text { node between the sub-resistances. }\end{array}$ & $\begin{array}{l}\text { 1) A constant temperature, equal to } T_{\mathrm{g}} \text {, is used for the } \\
\text { nodes corresponding to the radial boundary and to the } \\
\text { base of the domain; } 2 \text { ) Inlet temperature is expressed as } \\
\text { a function of the outlet loop temperature } T_{\text {out }} \text { by } \\
\mathrm{T}_{\text {in }}(\mathrm{t})=\mathrm{T}_{\text {out }}(\mathrm{t})+\Delta \mathrm{T}(\mathrm{t}) \text {. }\end{array}$ & $\begin{array}{l}\text { The model is based on the } \\
\text { Delta-circuit thermal } \\
\text { resistance method. }\end{array}$ & $\begin{array}{l}\text { 1) For the fluid region, the } \\
\text { max error is } 0.084^{\circ} \mathrm{C} ; 2 \text { ) For } \\
\text { the BHE region, the max } \\
\text { error is } 0.235^{\circ} \mathrm{C} \text {. }\end{array}$ & $\begin{array}{l}\text { This method is applied as } \\
\text { a response approach to } \\
\text { produce normalized } \\
\text { transfer functions. }\end{array}$ \\
\hline
\end{tabular}




\section{Further developments and EP foundation models}

\subsection{Innovative approach models}

Qi et al. [161] proposed a method that uses phase change material (PCM) as the backfill material to improve the BHE thermal behaviour. In this study, four backfill materials are utilized including the soil, paraffin RT27, acid and enhanced acid. The combined effect of the initial soil temperature and shank spacing on the BHE thermal performance is also analysed. Wei et al. [162] analysed a simplified CMILS model to decrease the computational time of the short-term step response g-functions for the vertical BHE. It is found that the model results are in agreement with the test data for the short-term operation. Kuzmix et al. [163] developed a 2D finite volume numerical model to examine the complex U-tube geometries. This model is applied to analyse and predict the temperature variation and the allowable 'ground fouling' within the hybrid and non-hybrid GSHP systems for long-term operation. Ruiz-Calvo et al. [142] proposed a borehole-to-ground (B2G) transient approach by integrating a 2D thermal grid model with a vertical discretization of the BHE region. The simulation results are validated against the experimental data in the GeoCool plant [143]. The results indicate that the B2G model can generate the outlet fluid temperatures for all experimental conditions. Lee [164] improved a 3D model [97] to analyse the short-term step performance of the BHE, by considering the effects of the working fluid flow within the U-tube pipe and the grout thermal capacitance. In this study, a 'plugflow' method is used to simulate the working fluid performance. BniLam and Al-Khoury [165] presented a semi-analytical approach for unsteady heat flow inside a single U-tube BHE with friction heat. The impact of friction heat is demonstrated based on a series of equations depicting heat flow within three individual components of the BHE. The time region is discretized by the spectral analysis method whereas the spatial region is discretized through the eigenfunction expansion approach. The main merit of the proposed model is that it can be utilized for many applications, such as high fluid viscosities and velocities, fluid flow in the narrow pipes with and without the composite materials. Dehkordi et al. [166] studied a tight BHE design with a small shank spacing to improve the heat transfer efficiency, whereby the impact of shank spacing on the BHE thermal resistances with a 3D finite element model is accurately investigated. Minaei and Maerefat [167] developed a simple 2D analytical approach for the BHE heat transfer model within a short-term period, and revealed that the average working fluid and the BHE wall temperature gained from the proposed analytical approach agree with the reference numerical data. The developed analytical approach is suitable for predicting the BHE short-term thermal response and can be integrated in building simulation software. $\mathrm{Hu}[168]$ studied a 3D analytical model in which the groundwater movement in multiple-layer geologies is considered to analyse the long-term temperature response of the soil nearby the BHE with an unbalanced dynamic load. It is found that the higher the groundwater velocity, the quicker the soil temperature stabilizes. The results also indicate that the closeness of the pipes to the BHE wall is more important than the pipe separation in reducing the BHE thermal resistance. The comparison of all the discussed proposed 2D and 3D models is presented in Table 9. 
Table 9 The comparison of 2D and 3D models.

\begin{tabular}{|c|c|c|c|c|c|c|c|c|c|c|c|c|}
\hline \multicolumn{13}{|c|}{ Comparison of 2D and 3D models } \\
\hline & \multirow[t]{2}{*}{ Model Name } & \multirow[t]{2}{*}{ Ref. } & \multirow[t]{2}{*}{ Methods } & \multirow[t]{2}{*}{ Operation time } & \multicolumn{8}{|c|}{ Impact factors } \\
\hline & & & & & $\begin{array}{l}\text { The effect } \\
\text { of axial } \\
\text { effect }\end{array}$ & $\begin{array}{l}\text { The fluid } \\
\text { temperature } \\
\text { variation } \\
\text { along the } \\
\text { pipe wall }\end{array}$ & $\begin{array}{l}\text { The effect } \\
\text { of thermal } \\
\text { capacity of } \\
\text { the soil }\end{array}$ & $\begin{array}{l}\text { The effect } \\
\text { of thermal } \\
\text { capacity of } \\
\text { the BHE }\end{array}$ & $\begin{array}{l}\text { The effect } \\
\text { of } \mathrm{BHE} \\
\text { thermal } \\
\text { resistance }\end{array}$ & $\begin{array}{l}\text { The effect } \\
\text { of thermal } \\
\text { short- } \\
\text { circuiting }\end{array}$ & $\begin{array}{l}\text { The } \\
\text { effect of } \\
\text { spacing } \\
\text { shack }\end{array}$ & $\begin{array}{l}\text { The effect of } \\
\text { groundwater } \\
\text { flow }\end{array}$ \\
\hline \multirow{13}{*}{$\begin{array}{c}2 \mathrm{D} \\
\text { models }\end{array}$} & 2D FVM model & $\begin{array}{l}\text { Yavuzturk C } \\
{[78,79]}\end{array}$ & FVM & Short time step & $\checkmark$ & $\mathbf{x}$ & $\mathbf{x}$ & $\mathbf{x}$ & $\mathbf{x}$ & $\mathbf{x}$ & $\checkmark$ & $\mathbf{x}$ \\
\hline & $\begin{array}{l}\text { Equivalent } \\
\text { Diameter Model }\end{array}$ & $\begin{array}{l}\text { Gu and } \\
\text { O'Neal [107, } \\
115]\end{array}$ & FDM & Transient & $x$ & $x$ & $\mathbf{x}$ & $\mathbf{x}$ & $\checkmark$ & $x$ & $\checkmark$ & $\mathbf{x}$ \\
\hline & EWS model & $\begin{array}{l}\text { Wetter M and } \\
\text { Huber A [109] }\end{array}$ & FDM & Short time step & $x$ & $x$ & $\checkmark$ & $\checkmark$ & $\mathbf{x}$ & $\mathbf{x}$ & $x$ & $\mathbf{x}$ \\
\hline & MISOS model & $\begin{array}{l}\text { Oppelt et al. } \\
{[110]}\end{array}$ & $\begin{array}{l}\text { Division } \\
\text { region } \\
\text { method }\end{array}$ & Long time step & $\checkmark$ & $\checkmark$ & $\mathbf{x}$ & $x$ & $\mathbf{x}$ & $\checkmark$ & $\checkmark$ & $\mathbf{x}$ \\
\hline & CaRM model & $\begin{array}{l}\text { Carli et al. } \\
{[111]}\end{array}$ & FDM & Short time step & $\checkmark$ & $x$ & $\checkmark$ & $x$ & $\checkmark$ & $x$ & $x$ & $\mathbf{x}$ \\
\hline & CMILS model & $\begin{array}{l}\text { Li and Yang } \\
{[113,114]}\end{array}$ & G-function & Short time step & $\checkmark$ & $\checkmark$ & $x$ & $x$ & $\checkmark$ & $x$ & $x$ & $x$ \\
\hline & $\begin{array}{l}\text { Improvement } \\
\text { CaRM }\end{array}$ & $\begin{array}{l}\text { Zerrella et al. } \\
{[125]}\end{array}$ & FDM & Long time step & $\checkmark$ & $\checkmark$ & $\checkmark$ & $\checkmark$ & $\checkmark$ & $x$ & $x$ & $\mathbf{x}$ \\
\hline & CaRM-He & $\begin{array}{l}\text { Zerrella et al. } \\
{[126,127]}\end{array}$ & FDM & Long time step & $\checkmark$ & $\checkmark$ & $\checkmark$ & $\checkmark$ & $\checkmark$ & $x$ & $x$ & $x$ \\
\hline & TRCM model & $\begin{array}{l}\text { Bauer et al. } \\
{[129,130]}\end{array}$ & $\begin{array}{l}\text { Delta- } \\
\text { circuit } \\
\text { theory }\end{array}$ & Short time step & $\checkmark$ & $x$ & $\checkmark$ & $\checkmark$ & $\checkmark$ & $x$ & $x$ & $x$ \\
\hline & MTRCM model & $\begin{array}{l}\text { Pasquier and } \\
\text { Marcotte } \\
{[131]}\end{array}$ & $\begin{array}{l}\text { Delta- } \\
\text { circuit } \\
\text { theory }\end{array}$ & Short time step & $\checkmark$ & $x$ & $\checkmark$ & $\checkmark$ & $\checkmark$ & $x$ & $\checkmark$ & $x$ \\
\hline & B2G model & $\begin{array}{l}\text { Ruiz-Calvo F } \\
\text { andRosa MD } \\
{[141-143]}\end{array}$ & $\begin{array}{l}\text { Thermal } \\
\text { network } \\
\text { model }\end{array}$ & Short time step & $\checkmark$ & $\checkmark$ & $\checkmark$ & $\checkmark$ & $\checkmark$ & $x$ & $\checkmark$ & $x$ \\
\hline & $\begin{array}{l}\text { A homespun 2D } \\
\text { model }\end{array}$ & $\begin{array}{l}\text { Kuzmic et } \\
\text { al.[144] }\end{array}$ & FVM & Long time step & $\checkmark$ & $\checkmark$ & $x$ & $x$ & $\checkmark$ & $x$ & $x$ & $x$ \\
\hline & $\begin{array}{l}\text { Semi-analytical } \\
\text { model }\end{array}$ & $\begin{array}{l}\text { Belzile et al. } \\
{[145]}\end{array}$ & FVM & Long time step & $\checkmark$ & $\checkmark$ & $x$ & $x$ & $\checkmark$ & $x$ & $x$ & $x$ \\
\hline
\end{tabular}




\begin{tabular}{|c|c|c|c|c|c|c|c|c|c|c|c|c|c|}
\hline & \multicolumn{2}{|c|}{$\begin{array}{lr}\text { New } & 2 \mathrm{D} \\
\text { analytical model }\end{array}$} & \begin{tabular}{|l|} 
Lamarche \\
{$[146]$}
\end{tabular} & \begin{tabular}{|l|} 
Equivalent \\
method
\end{tabular} & Short time step & $\checkmark$ & $\checkmark$ & $x$ & $x$ & $\checkmark$ & $x$ & $\checkmark$ & $x$ \\
\hline \multirow{7}{*}{$\begin{array}{l}3 \mathrm{D} \\
\text { models }\end{array}$} & \multicolumn{2}{|c|}{$\begin{array}{ll}\text { Al-Khoury } & \mathrm{R} \\
\text { model } & \end{array}$} & $\begin{array}{l}\text { Al-Khoury } \\
\text { and Bonnier } \\
{[99,100]}\end{array}$ & FEM & $\begin{array}{l}\text { Long or short } \\
\text { time step }\end{array}$ & $\checkmark$ & $\checkmark$ & $x$ & $x$ & $\checkmark$ & $\checkmark$ & $\checkmark$ & $\checkmark$ \\
\hline & \multicolumn{2}{|c|}{$\begin{array}{l}\text { Nabi M. FVM } \\
\text { model }\end{array}$} & \begin{tabular}{|l|} 
Nabi and Al- \\
Khoury. [151, \\
$152]$
\end{tabular} & FVM & Long time step & $\checkmark$ & $\checkmark$ & $x$ & $x$ & $\checkmark$ & $\checkmark$ & $\checkmark$ & $x$ \\
\hline & \multicolumn{2}{|c|}{ MDF model } & $\begin{array}{l}\text { Wołoszyn and } \\
\text { Gołas [157- } \\
159]\end{array}$ & FEM & Long time step & $\checkmark$ & $\checkmark$ & $x$ & $x$ & $\checkmark$ & $x$ & $x$ & $x$ \\
\hline & \multicolumn{2}{|c|}{ Spectral model } & $\begin{array}{l}\text { BniLam and } \\
\text { Al-Khoury } \\
{[165]}\end{array}$ & $\begin{array}{l}\text { Fourier } \\
\text { transform }\end{array}$ & Long time step & $\checkmark$ & $\checkmark$ & $x$ & $x$ & $x$ & $x$ & $x$ & $x$ \\
\hline & \multirow{3}{*}{$\begin{array}{l}\text { 3D } \\
\text { TRC } \\
\text { M } \\
\text { model }\end{array}$} & $\begin{array}{l}\text { Based } \\
\text { on FDM }\end{array}$ & $\begin{array}{l}\text { Bauter et al. } \\
{[129,130]}\end{array}$ & FDM & Short time step & $\checkmark$ & $\checkmark$ & $\checkmark$ & $\checkmark$ & $\checkmark$ & $x$ & $x$ & $x$ \\
\hline & & $\begin{array}{l}\text { Based } \\
\text { on FEM }\end{array}$ & $\begin{array}{l}\text { Diersch et al. } \\
{[154,155]}\end{array}$ & FEM & Long time step & $\checkmark$ & $\checkmark$ & $x$ & $\checkmark$ & $\checkmark$ & $x$ & $x$ & $\checkmark$ \\
\hline & & $\begin{array}{l}\text { 3D } \\
\text { MTRC } \\
\text { M } \\
\text { model }\end{array}$ & $\begin{array}{l}\text { Pasquier and } \\
\text { Marcotte } \\
{[160]}\end{array}$ & $\begin{array}{l}\text { Delta- } \\
\text { circuit } \\
\text { thermal } \\
\text { resistance }\end{array}$ & Long time step & $\checkmark$ & $\checkmark$ & $\checkmark$ & $\checkmark$ & $\checkmark$ & $x$ & $x$ & $x$ \\
\hline
\end{tabular}




\subsection{EP foundation models}

For the GSHP system, a large and expensive land area is needed for mounting the BHEs. Unfortunately, the required land is unavailable in some urban regions. Thereby, the utilization of building pile foundations as BHEs have attracted much attention for decreasing the expense and land area as well as improving the heat transfer rate [13, 169-171]. Fig.27 shows a EP foundation.

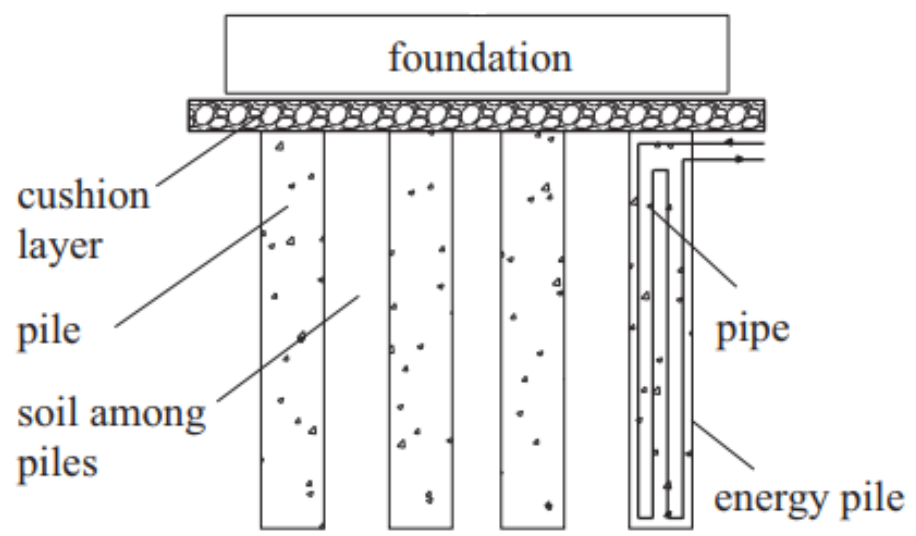

Fig.27. The EP foundation construction [172].

An EP has a dual-function composed of the building foundation and heat exchanger. The impact of thermal medium on the pile mechanical load requires to be analysed. The EP heat transfer mechanism is similar to that of a BHE system. The thermal energy is transferred from the ground to the EP in heat extraction period and vice versa in heat rejection period. Although direct energy or exergy analysis utilized for a conventional GSHP system [13, 173-175] has not been applied to the EP system, it is confirmed that the EP system is more efficient as it improves the heat transfer and heat storage due to the existence of the concrete nearby the pipe. Bozis et al. [170] presented an approach to assess the design options for cast-in-place EPs which depend on the line source theory. The results indicate that the temperature variation at the axis of a pile does not rely on the pipe geometrical construction, heat flow condition and the number of U-tubes. Hu et al. [176] proposed a new composite cylindrical EP analytical model which is used to study the unsteady heat transfer during the early period of thermal response, in which the pile heat capacity is also considered. Subsequently, a validation is made between the results of the developed analytical method and that of the 3D numerical method which indicates that both agree. Gao et al. [177] developed a numerical method for the W-shaped tube based on the solid/fluid coupled heat transfer within the EP by considering the energy conservation of the working fluid, soil and concrete pile. It is found that there is uniformity between the numerical and the experimental results. The W-shaped EP is preferred as the most efficient one for the practical application in terms of thermal performance. Lalouin et al. [178] developed a numerical thermo-hydro-mechanical (THM) approach to assess the heat transfer within the saturated soil porous media. This Biot-type model is studied based on the homogenization theory [179]. Bandos et al. [180-182] proposed the finite cylindrical source model with constant heat flow embedded into a semi-infinite medium to assess the temperature variation of an arbitrary B configuration within the EP. Loveridge and Powrie [183] proposed a 2D analytical model based on thermal resistance theory 
to investigate the heat transfer process within a pile. In addition, it is also used to determine the shape factors for various piles and pipe geometries. The results are then employed to define the limits of the traditional design assumptions, and establish an empirical equation for calculating the temperature variations of the ground and working fluid.
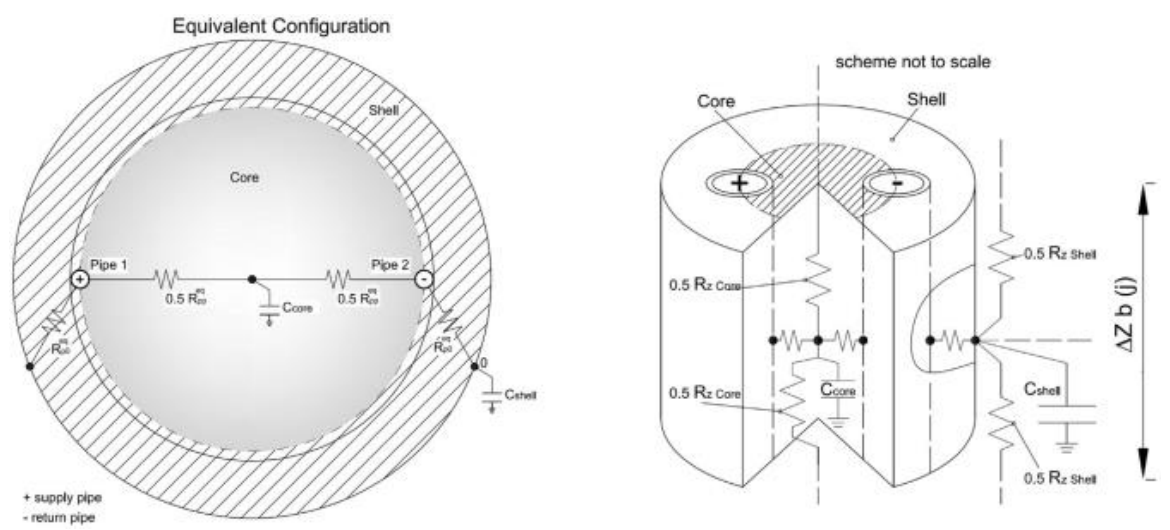

Fig.28. The EP modelling approach [184].

Zarrella et al. [184] examined the helical and triple U-tube configurations within the EPs through numerical simulation and measurement as shown in Fig.28. The numerical model is developed based on the improved CaRM method [129], which is used to investigate the transient heat transfer issues and evaluate n-U-tubes performance through using the electrical analogy theory. The thermal capacity of the BHE is also considered including both the working fluid and the grouting material. It is concluded that the helical-pipe EP has better heat behaviour than the triple U-tube.

\section{Previous reviews on BHE model}

Several researches have reviewed the state-of-the-art and the worldwide adoption of the BHE. As a result, the recent reviews are covered in this section. Yang et al. [12] summed up the normal simulation models of the vertical BHE systems. The different types of simulation programs for the vertical BHE units are also covered in the same study. Lamarche et al. [56] reviewed the 2D thermal borehole resistance approaches to compare the equations used to assess the heat transfer behaviour of the GSHP. Meanwhile, the impact of the axial temperature variation on the BHE design is also investigated using a 3D numerical model. Moreover, the authors have also developed a novel method to calculate the borehole interior thermal resistances and heat flow rate. Ruan et al. [51] made a summary on the cylinder source, line source, 2D and 3D numerical models to analyse heat transfer performance within single and multiple BHE systems. The work raises awareness of various hypotheses and methodologies for these models with their merits and demerits clearly outlined. Atam and Helsen [185] presented the state-of-the-art heat transfer models of the BHE system and summarized in detail the optimal control models. The pros and cons of each control method are articulated and the factors influencing the heat transfer rate are presented. In the meantime, the practical projects on the optimal control of the GSHP or hybrid GSHP system are also discussed including some suggestions on the future work. In another review [186], some case studies and relevant results are presented based on the optimal design of the BHE. Li and Lai [187] provided 
an overview of the heat transfer processes within the BHE and EP through diverse analytical models, and summarised the thermal variation process of the BHE with time and space scales where six analytical approaches are compared. They also gave some critical references, descriptive details and the challenging issues on heat transfer rate. Soni et al. [188] summarised the past researches in the form of test and numerical studies and posed some critical questions the behaviours of the earth-air heat exchanger (EAHE) and GSHP systems, with the advantages and disadvantages of 1D, 2D and 3D models. Through analysis and comparison, it is noted that the GSHP system has 10\%-20\% higher energy saving than the EAHE system. Spitler and Gehlin [189] clarified the historical perspective and development of GSHP system during the period between the 1980s and 1990s. Bayer et al. [48] demonstrated the development process of the GSHP technology for reducing the GHG emissions since 2000 and discussed the amounts and capacities in various counties over the previous decade. The analysis of results indicate that 3.7 million tons of $\mathrm{CO}_{2}$ can be saved in comparison to the traditional technologies. Luo et al. [190] examined the previous works on the soil investigation for the BHE. Briefly, the study is classified chiefly into three groups: investigation of hydraulic properties, determination of thermal properties and thermo-physical properties of the common geological materials. Moel et al. [13] examined the technical background, environmental effects and operation experiences of the EP system in the past decades. Suryatriyastuti et al. [191] analysed the heat transfer mechanism within the pile foundation. The method is recommended to meet the thermal and structural capacities by carefully designing a system in geotechnical and mechanical aspects. The main advantage of these EPs is the foundation components that serve as heat exchangers needed for structural purpose but not necessary to be installed separately. On the other hand, the concrete as the heat transfer intermediate in the EP system improves the system efficiency owning to its high thermal conductivity and capacity. As a result, in addition to significantly reducing the installation cost and land utilization, the EP foundations can increase the thermal productivity and preserve the environmental sustainability. Several reviews have been presented regarding the main issues in the application where it is observed that the effect of thermal energy generated depends upon the ground, saturation degree, groundwater flow and specifications of the heat pump system. Faizal et al. [192] also reviewed the multidisciplinary approaches to improve the performance of each component within the EP system. The nanofluid proposed by the authors is regarded as the working fluid to improve the fluid conductive-convective heat transfer.

\section{Important observations and recommendations for future research}

The development of BHE heat transfer models is a significant challenging field of research. The models are regarded as a critical tool for predicting the thermal performance of a BHE system, which consider the thermal interaction of the BHEs, the impact of the groundwater flow and dynamic soil surface boundary condition, soil property, long-term and short-term operations and so on. Furthermore, some approaches are also essential to evaluate the environmental and economic benefits of the GSHP system. Nevertheless, few researches on 2D and 3D heat transfer models for the vertical BHE have been summarized in detail. 
The majority of the 2D models are developed via the thermal network and delta-circuit thermal resistance methods, in which the BHE and nearby soil are presented using a sequence of temperature nodes linked by thermal resistances. Many modifications have been proposed based on the thermal resistance network, typically by adding more nodes to the grid, or classifying the BHE into two or more regions, on the basis of the interior BHE geometrical construction. Nevertheless, when higher precision is needed, more nodes need to be added, leading to a large number of equations that must be appropriately resolved to suit for a long-term simulation demand. Because of a great number of differential equations required for an adequate discretization within the $\mathrm{BHE}$ region, some models are restricted to the $2 \mathrm{D}$ depiction.

The 3D models are more dynamic and implemented by applying the advanced technology. They can provide the most accurate description of all physical characteristics of the BHE. In other words, the 3D models allow any type of geometry that contributes to calculating the temperature variations surrounding the BHE and in the depth of the soil. On the other side, the 3D models can evaluate the dynamic working fluid flow along the pipe loop. Various soil layers can be explicitly included in the analysis and the effect of the climate change on the soil surface boundary layer can be assumed. The 3D models can also be employed to determine the effects of the working flow rate, shank spacing, thermal conductivities of the soil and grout, BHE depth on the mean heat flux per unit length, thermal short-circuiting loss rate and outlet fluid temperature. Although more effort has been concentrated on the improvement and application of the 2D and 3D models, there are still a few fields that need to be given attention to make the framework for the future research so as to extend the applicability of GSHP technology. These fields are summarized as follows:

$>$ The most current simulation approaches have never considered the effect of the groundwater movement on the performance of the BHE system, where the thermal interaction is greatly sensitive to the BHE number, depth and spacing. Hence, future research should concentrate on this aspect.

$>$ The dynamic soil surface temperature should not be assumed as a constant value or an adiabatic boundary value owing to many complex procedures and interactions taking place within the nearby surface. In other words, a precise numerical model must consider the effects of the wind speed, ambient temperature, solar radiation, cloud cover, relative humidity, rainfall, snow cover and surface reflectivity.

$>$ The computer programs should be verified through the experimental data and a comprehensive evaluation is extremely required to study their applicability for academic and engineering practices.

\section{Conclusions}

The analytical and numerical models for the vertical BHE in the GSHP system have been presented to clarify the complicated heat transfer mechanism between the ground and the BHE. As a result, an overview of the currently available 2D and 3D vertical BHE models has been presented and some critical conclusions are drawn as follows: 
The heat transfer models of various BHE geometrical configurations have been discussed including the W-shaped, helical shape, coaxial shape, single, double and triple U-tube loops. The double U-tube loop has been noted with superior performance compared to the single and multiple U-tube loops. On the other hand, both the coaxial and helical pipe loops have been noted with better performance in terms of heat exchange in comparison with the U-tube pipe loop.

The majority of the 2D models are developed based on the delta-circuit thermal resistance method, in which the BHE and nearby soil are represented with a set of temperature nodes linked through the thermal resistances. The typical thermal network is noted as the delta grid, with one node on each U-tube pipe and the other node at the BHE wall. Several modifications to the thermal resistance grids are proposed, typically by adding more nodes to the grid, or by classifying the BHE into two or more regions, based on the interior BHE geometrical construction. It has been emphasized that the 2D models can also be applied for simulating the performance of the GSHP, soil temperature, BHE wall temperature in addition to the inlet and outlet fluid temperatures. Owing to a considerable number of differential equations required for sufficient discretization of the BHE region, some approaches are restricted to $2 \mathrm{D}$ representation. Although the $2 \mathrm{D}$ models require less computing effort, they are less suited for the comprehensive design and simulation. To address the above issues, many studies have been implemented to investigate the heat transfer within BHEs by using the 3D models.

The 3D models have been found to be advantageous because the working fluid temperature can be accurately simulated. Different layers of the soil can be explicitly catered for based on the weather, boundary and initial conditions at the ground surface. The soil region underneath the BHEs is considered, and the heat transfer at the bottom of the U-tube can be evaluated as well. The thermal interferences among the multiple BHEs can be investigated, in addition to the other benefits of the 3D models like the determination of the effects of the undisturbed ground temperature, thermal short-circuiting between two legs of the U-tube and groundwater movement on heat exchange. However, the main disadvantage of the 3D discretized models is their long computing time because of the complicated heat transfer and discretization processes.

In terms of future studies, firstly, different computer programs should be further verified by experimental data, and a comprehensive assessment is greatly required to clarify their accuracies to boost the confidence of their applications for research and engineering practices. Secondly, the effects of the wind speed, ambient temperature, solar radiation, cloud cover, relative humidity, rainfall, snow cover and surface reflectivity should be considered in the numerical models. Finally, an ideal design solution for GSHP systems is extremely required, which can deal with the simultaneous interactions among the BHEs, supplemental heat extraction or rejection of the GSHP systems. 


\section{Acknowledgement}

We thank the authors of the cited references for granting the copyright and publishing permissions related to the figures included in this paper.

\section{References}

[1] Alkaff SA, Sim SC, Ervina EMN. A review of underground building towards thermal energy efficiency and sustainable development. Renewable and Sustainable Energy Reviews 2016; 60: 692-713.

[2] Saboori B, Sulaiman J, Mohd S. Economic growth and $\mathrm{CO}_{2}$ emissions in Malaysia: a co-integration analysis of the environmental Kuznets curve. Energy Policy 2012; 51: 184-191.

[3] Fay JA, Golomb DS. Energy and the environment. Oxford: Oxford University Press, 2002.

[4] Yusof AB. Analysis of renewable energy potential in Malaysia. Faculty of Engineering, University of Malaya, Kuala Lumpur; 2011 [Doctoral Thesis].

[5] Herbert GMJ, Iniyan S, Sreevalsan E, Rajapandian S. A review of wind energy technologies. Renewable and Sustainable Energy Reviews 2007; 11: 1117-1145.

[6] Trieb F, Schillings C, O'Sullivan M, Pregger T, Hoyer-Klick C. Global potential of concentrating solar power. Solar PACES. Berlin, Germany. Available at: <www.dlr.de/tt///DNI-Atlas-SP-Berlin 20090915-04-Final-Colour.pdf 2> 2014 [Accessed 02.11.14].

[7] Bai Z, Liu Q, Lei J, Wang X, Sun J, Jin H. Thermodynamic evaluation of a novel solar-biomass hybrid power generation system. Energy Conversion and Management 2017; 142: 296-306.

[8] Guney MS. European energy policy and renewable energies and application possibility in Turkey. Danube Krems University in Austria 2005 [Master Thesis].

[9] Bleicher A, Gross M. Geothermal heat pumps and the vagaries of subterranean geology: Energy independence at a household level as a real world experiment. Renewable and Sustainable Energy Reviews 2016; 64: 279-288.

[10] Florides GA, Pouloupatis PD, Kalogirou S, Messaritis V, Panayides I, Zomeni Z. The geothermal characteristics of the ground and the potential of using ground coupled heat pumps in Cyprus. Energy 2011; 36: 5027-5036.

[11] Yang W, Zhou J, Xu W, Zhang G. Current status of ground-source heat pumps in China. Energy Policy 2010; 38: 323-332.

[12] Yang H, Cui P, Fang Z. Vertical-borehole ground-coupled heat pumps: a review of models and systems. Applied Energy 2010; 87: 16-27.

[13] Moel M, Bach PM, Bouazza A, Singh RM, Sun JLO. Technological advances and applications of geothermal energy pile foundations and their feasibility in Australia. Renewable and Sustainable Energy Reviews 2010; 14: 2683-2696. 
[14] Blum P, Campillo G, Koelbel T. Techno-economic and spatial analysis of vertical ground source heat pump systems in Germany. Energy 2011; 36: 3002-3011.

[15] Bakirci K, Ozyurt O, Comakli K, Comakli O. Energy analysis of a solar-ground source heat pump system with vertical closed-loop for heating applications. Energy 2011; 36: 3224-3232.

[16] Yu X, Wang R, Zhai X. Year round experimental study on a constant temperature and humidity air-conditioning system driven by ground source heat pump. Energy 2011; 36: 1309-1318.

[17] Karytsas S, Theodoropoulou H. Public awareness and willingness to adopt ground source heat pumps for domestic heating and cooling. Renewable and Sustainable Energy Reviews 2014; 34: 49-57.

[18] Zhang W, Yang H, Fang L, Cui P, Fang Z. Study on heat transfer of pile foundation ground heat exchanger with threedimensional groundwater seepage. International Journal of Heat and Mass Transfer 2017; 105: 58-66.

[19] Sarbu L, Sebarchievici C. General review of ground-source heat pump systems for heating and cooling of buildings. Energy and Buildings 2014; 70: 441-454.

[20] Spitler JD. Ground-source heat pump system research-past present and future. HVAC \& R Research 2005; $11(2)$ : $165-167$.

[21] Luo J, Rohn J, Bayer M, Priess A, Wilkmann L, Xiang W. Heating and cooling performance analysis of a ground source heat pump system in Southern Germany. Geothermics 2015; 53: 57-66.

[22] Blum P, Campillo G, Kölbel T. Techno-economic and spatial analysis of vertical ground source heat pump systems in Germany. Energy 2011; (36): 3002-3011.

[23] Lee JY. Current status of ground source heat pumps in Korea. Renewable and Sustainable Energy Reviews 2009; 13: 15601568 .

[24] Zhang L, Zhang Q, Li M, Du Y. A new analytical model for the underground temperature profile under the intermittent operation for ground-coupled heat pump systems. Energy Procedia 2015; 75: 840-846.

[25] Lund JW, Boyd TL. Direct utilization of geothermal energy 2015 worldwide review. Geothermics 2016; 60: 66-93.

[26] Ball DA, Fischer RD, Hodgett DL. Design methods for ground-source heat pumps. ASHRAE Transactions 1983; 89 (2B): $416-40$.

[27] Stuebi RT. Geothermal heat pumps: green for your wallet, green for our planet. In: Renewable Energies Conference, Denver, USA 2000.

[28] Ingersoll LR, Plass HJ. Theory of the ground pipe source for the heat pump. ASHVE Transactions 1948; 54: 339-348.

[29] IGSHPA. Closed-loop/ground-source heat pump systems - Installation guide 1988.

[30] Kavanaugh SP, Rafferty K. Ground-source heat pumps, design of geothermal systems for commercial and institutional buildings. Atlanta: ASHRAE 1997. 
[31] Bose JE, Parker JD, McQuiston FC. Design/data manual for closed-loop ground coupled heat pump systems. Oklahoma State University for ASHRAE 1985.

[32] Donna AD, Loria A F.R, Laloui L. Numerical study of the response of a group of energy piles under different combinations of thermos-mechanical loads. Computers and Geotechnics 2016; 72: 126-142.

[33] Yoon S, Lee SR, Xue JF, Zosseder K, Go GH, Park H. Evaluation of the thermal efficiency and a cost analysis of different types of ground heat exchangers in energy piles. Energy Conversion and Management 2015; 105: 393-402.

[34] Gao J, Zhang X, Liu J, Li K, Yang J. Thermal performance and ground temperature of vertical pile-foundation heat exchanger: a case study. Apply Thermal Engineering 2008; 28: 2295-3304.

[35] Hamada Y, Saitoh H, Nakamura M, Kukbota H, Ochifuji K. Field performance of an energy pile system for space heating. Energy and Buildings 2007; 39 (5): 517-524.

[36] Man Y, Yang H, Diao N, Li X, Cui P, Fang Z. Development of spiral heat source model for novel pile ground heat exchangers. HVAC \&R Research 2011; 17 (6): 1075-1088.

[37] Brandl H. Energy foundations and other thermo-active ground structures. Geotechnique 2006; 56: 81-122.

[38] Lamarche L, Beauchamp B. New solutions for short-time analysis of geothermal vertical boreholes. International Journal of Heat and Mass Transfer 2007; 50: 1408-1419.

[39] Brandl H. Thermo-active: ground-source structures for heating and cooling. Procedia Engineering 2013; 57: 9-18.

[40] Al-Khoury R. Computational modelling of shallow geothermal Systems, CRC Press/ Balkema and Taylor\& Francis Group publication, London, UK, ISBN:978-0-415-59627-5(Hbk) 2012 p. 31-45,

[41] Kavanaugh SK, Rafferty K. Ground-source heat pumps: design of geothermal systems for commercial and institutional buildings. Atlanta (GA): American Society of Heating, Refrigerating and Air-Conditioning Engineers, Inc. 1997.

[42] Gao J, Zhang X, Liu J, Li K, Yang J. Thermal performance and ground temperature of vertical pile-foundation heat exchanger: a case study. Apply Thermal Engineering 2008; 28: 2295-2304.

[43] Hamada Y, Saitoh H, Nakamura M, Kukbota H, Ochifuji K. Field performance of an energy pile system for space heating. Energy and Buildings 2007; 39(5): 517-524.

[44] Staffell I, Brett D, Brandon N, Hawkes A. A review of domestic heat pumps. Energy Environment Science 2012; 5: 92919306.

[45] Omer AM. Ground-source heat pumps systems and applications. Renewable and Sustainable Energy Reviews 2008; 12: $344-371$.

[46] Zhai X, Qu M, Yu X, Yang Y, Wang R. A review for the applications and integrated approaches of ground-coupled heat pump systems. Renewable and Sustainable Energy Reviews 2011; 15: 3133-3140. 
[47] Self SJ, Reddy BV, Rosen MA. Geothermal heat pump systems: status review and comparison with other heating options. Applied Energy 2013; 101: 341-348.

[48] Bayer P, Saner D, Bolay S, Rybach L, Blum P. Greenhouse gas emission savings of ground source heat pump systems in Europe: a review. Renewable and Sustainable Energy Reviews 2012; 16: 1256-1267.

[49] Lee JY. Current status of ground source heat pumps in Korea. Renewable and Sustainable Energy Reviews 2009; 13: 15601568.

[50] Yuan Y, Cao X, Sun L, Lei B, Yu N. Ground source heat pump system: a review of simulation in China. Renewable and Sustainable Energy Reviews 2012; 16: 6814-6822.

[51] Ruan W, Horton.WT. Literature review on the calculation of vertical ground heat exchangers for geothermal heat pump

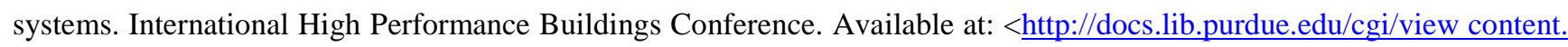

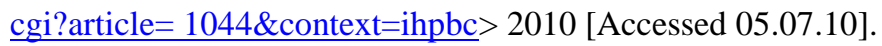

[52] Ingersoll LR, Zobel OJ, Ingersoll AC. Heat conduction: with engineering, geological and other applications, Madison University of Wisconsin Press, Madison 1954; p.325.

[53] Carslaw HS, Jaeger JC. Conduction of heat in solids, Claremore Press, Oxford 1959.

[54] Hart DP, Couvillion R. Earth coupled heat transfer, National Water Well Association 1986.

[55] IGSHPA. Design and installation standards, Stillwater, International Ground Source Heat Pump Association, Oklahoma 1991.

[56] Kavanaugh, SP. Simulation and experimental verification of vertical ground-coupled heat pump systems, Oklahoma State University, Stillwater 1985 [Doctoral Thesis].

[57] Eskilson P. Thermal analysis of heat extraction boreholes. Department of Mathematical Physics and Building Technology, University of Lund, Sweden 1987 [Doctoral Thesis].

[58] Hellström G. Ground heat storage: thermal analyses of duct storage system: University of Lund, Sweden 1991.

[59] Rottmayer SP, Beckman WA, Mitchell W. Simulation of a single vertical U-tube ground heat exchanger in an infinite medium. ASHRAE Transactions 1997; 103: 651-659.

[60] Shonder JA Beck JV. Determining effective soil formation thermal properties from field data using parameter estimation technique United States. Department of Energy Office of Energy Efficiency and Renewable Energy 1998.

[61] Lee CK, Lam HN. Computer simulation of borehole ground heat exchanger for geothermal heat pump systems. Renewable Energy 2008; (33): 1286-1296.

[62] Capozza A, Carli MD, Zarrella A. Design of borehole heat exchangers for ground-source heat pumps: a literature review, methodology comparison and analysis on the penalty temperature. Energy and Buildings 2012; 55: 369-379. 
[63] Rainieri S, Bozzoli F, Pagliarini G. Modeling approaches applied to the thermal response test: a critical review of the literature. HVAC \& R Research 2011; 17(6): 977-990.

[64] Raymond J, Therrien R, Gosselin L, Lefebvre R. A review of thermal response test analysis using pumping test concepts. Ground Water 2011; 49 (6): 932-945.

[65] Zhang C, Guo Z, Liu Y, Cong X, Peng D. A review on thermal response test of ground-coupled heat pump systems. Renewable and Sustainable Energy Reviews 2014; 40: 851-867.

[66] Lamarche L, Kajl S, Beauchamp B. A review of methods to evaluate borehole thermal resistances in geothermal heat-pump systems. Geothermics 2010; 39: 187-200.

[67] Li M, Lai ACK. New temperature response functions ( $\mathrm{G}$ functions) for pile and borehole ground heat exchangers based on composite-medium line-source theory, Energy 2012; 38: 255-263.

[68] Thomson W. Mathematical and physical papers. University of Cambridge Press 1954.

[69] Carslaw H S, Jaeger JC. Conduction of heat in solid, Oxford, Claremore Press 1947.

[70] Ingersoll LR, Plass HJ. Theory of the ground pipe heat source for the heat pump. ASHVE Transactions 1948; 47: 339-348.

[71] Zeng H, Diao N, Fang Z. Heat transfer analysis of boreholes on vertical ground heat exchangers. International Journal of Heat and Mass Transfer 2003; 46: 4467-4481.

[72] Hart DP, Couvillion R. Earth coupled heat transfer. Publication of the National Water Well Association 1986.

[73] Bose JE, MD Smith, Spitler JD. Advances in ground source heat pump systems. Proceedings of the Seventh International Energy Agency Heat Pump Conference 2002; 1:313-324.

[74] Ingersoll LR, Zobel OJ, Ingersoll AC. Heat conduction with engineering, geological, and other applications. New York: McGraw-Hill 1954

[75] Kavanaugh SP. A design method for commercial ground-coupled heat pumps. ASHRAE Transactions 1995; 101(2): 10881094.

[76] Kavanaugh SP. Field test of a vertical ground coupled heat pump in Alabama. ASHRAE Transactions 1992.

[77] Deerman JD, Kavanaugh SP. Simulation of vertical U-tube ground coupled heat pump systems using the cylindrical heat source solution. ASHRAE Transactions 1991; 97(1): 287-295.

[78] Yavuzturk C. Modeling of vertical ground loop heat exchangers for ground source heat pump systems. Oklahoma State University 1999 [Doctoral Thesis].

[79] Yavuzturk C, Spitler JD. A short time step response factor model for vertical ground loop heat exchangers. ASHRAE Transactions 1999; 105: 475-485. 
[80] Bernier MA, Pinel P, Labib R, Paillot R. A multiple load aggregation algorithm for annual hourly simulations of GCHP systems. HVAC \& R Research 2004; 10 (4): 471-487.

[81] Young TR. Development, verification, and design analysis of the borehole fluid thermal mass model for approximating short term borehole thermal response. Oklahoma State University 2004 [Master Thesis].

[82] Lamarche L, Beauchamp B. A new contribution to the finite line source model for geothermal boreholes. Energy and Buildings 2007; 39 (2): 188-198.

[83] Eskilson P, Claesson J. Simulation model for thermally interacting heat extraction boreholes. Numerical Heat Transfer 1988; 13: $149-165$.

[84] Yang W, Shi M, Liu G, Chen Z. A two-region simulation model of vertical U-tube ground heat exchanger and its experimental verification. Applied Energy 2009; 86: 2005-2012.

[85] Yavuzturk C, Chiasson AD, Nydahl JE. Simulation model for ground loop heat exchangers. ASHRAE Transactions 2009; $115(2): 45-59$.

[86] Hellström G. Duct ground heat storage model, manual for computer Code. Department of Mathematical Physics, University of Lund, Sweden 1989.

[87] Rottmayer SP, Beckman WA, Mitchell JW. Simulation of a single vertical U-tube ground heat exchanger in an infinite medium. ASHRAE Transactions 1997; 103 (2): 651-9.

[88] Rotameter SP. Simulation of ground coupled vertical U-tube heat exchangers. University of Wisconsin 1997.

[89] Gehlin SEA, Hellström G. Influence on thermal response test by groundwater flow in vertical fractures in hard rock. Renewable Energy 2003; 28 (14): 2221-2238.

[90] Chiasson AD, Rees SJ, Spitler JD. A preliminary assessment of the effects of groundwater flow on closed-loop groundsource heat pump systems. ASHRAE Transactions 2000; 106 (1): 380-393.

[91] He M, Rees SJ, Shao L. Applications of a dynamic three-dimensional numerical model for borehole heat exchangers, in: Effstock, Stockholm 2009.

[92] He M, Rees SJ, Shao L. Simulation of a domestic ground source heat pump system using a three-dimensional numerical borehole heat exchanger model, Journal of Building Performance Simulation 2011; 4 (2): 141-155.

[93] Marcotte D, Pasquier P. On the estimation of thermal resistance in borehole thermal conductivity test. Renewable Energy 2008; 33 (11): 2407-2415.

[94] Koohi-Fayegh S, Rosen MA. An analytical approach to evaluating the effect of thermal interaction of geothermal heat exchangers on ground heat pump efficiency. Energy Conversion and Management 2014; 78: 184-192. 
[95] Bandyopadhyay G, Gosnold W, Mann M. Analytical and semi-analytical solutions for short-time transient response of ground heat exchangers. Energy and Buildings 2008; 40 (10): 1816-1824.

[96] Sliwa T, Gonet A. Theoretical model of borehole heat exchanger. Journal of Energy Resources Technology, ASME 2005; 27: $142-148$.

[97] Lee CK, Lam NH. Computer simulation of borehole ground heat exchangers for geothermal heat pump systems. Renewable Energy 2008; 33: 1286-1296.

[98] Muraya, NK. Numerical modelling of the transient thermal interface of vertical U-tube heat exchangers. Texas A\&M University, USA 1994 [Doctoral Thesis].

[99] Al-Khoury R, Bonnier PG, Brinkgreve, RBJ. Efficient finite element formulation for geothermal heating systems. Part I: steady state. International Journal for Numerical Methods in Engineering 2005; 63: 988-1013.

[100] Al-Khoury R, Bonnier PG. Efficient finite element formulation for geothermal heating system. Part II: transient. International Journal for Numerical Methods in Engineering 2006; 67: 725-745.

[101] Al-Khoury R, Kolbel T, Schramedei R. Efficient numerical modelling of borehole heat exchangers. Computers and Geosciences 2010; 36: 1301-1315.

[102] Marcotte D, Pasquier P. Fast fluid and ground temperature computation for geothermal ground-loop heat exchanger systems. Geothermics 2008; 37 (6): 651-665.

[103] Raymond J, Therrien R, Gosselin L. Borehole temperature evolution during thermal response tests. Geothermics 2011; 40 (1): 69-78.

[104] Raymond J, Lamarche L, Malo M. Extending thermal response test assessments with inverse numerical modeling of temperature profiles measured in ground heat exchangers. Renewable Energy 2016; 99: 614-621.

[105] Rees SJ. An extended two-dimensional borehole heat exchanger model for simulation of short and medium timescale thermal response. Renewable Energy 2015; 83: 518-526.

[106] Rees SJ, Spitler JD, Deng Z, Orio CD, Johnson CN. A study of geothermal heat pump and standing column well performance. ASHRAE Transactions 2004; 110 (1): 3-13.

[107] Gu Y, O’Neal DL. An analytical solution to transient heat-conduction in a composite region with a cylindrical heat source. Journal of solar engineering 1995; 3: 242-248.

[108] Beier RA, Smith MD. Minimum duration of in-situ tests on vertical boreholes. ASHRAE Transactions 2003; 109: 475486.

[109] Wetter M, Huber A. TRNSYS Type 451: Vertical borehole heat exchanger EWS model, Version 3.1-model description and implementing into TRNSYS. Transsolar GmbH, Stuttgart, Germany 1997. 
[110] Oppelt T, Riehl I, Gross U. Modelling of the borehole filling of double U-tube heat exchangers. Geothermics 2010; 39: $270-276$

[111] Carli MD, Tonon M, Zarrela M, Zecchin R. A computational capacity resistance model (CaRM) for vertical groundcoupled heat exchangers. Renewable Energy 2010; 35: 1537-1550.

[112] Bauer D, Heidemann W, Diersch HJG. Transient 3D analysis of borehole heat exchanger modeling. Geothermics 2011; 40: $250-60$.

[113] Li M, Lai ACK. Analytical model for short-time responses of ground heat exchangers with U-shaped tubes: model development and validation. Applied Energy 2013; 104: 510-516.

[114] Yang Y, Li M. Short-time performance of composite-medium line-source model for predicting responses of ground heat exchangers with single U-shaped tube. International Journal of Thermal Sciences 2014; 82: 130-137.

[115] Gu Y, O’Neal DL. Development of an equivalent diameter expression for vertical U-tubes used in ground-coupled heat pumps. ASHRAE Transactions 1998; 104: 347-355.

[116] Bandyopadhyay G, Gosnold W, Mann M. Analytical and semi-analytical solutions for short-time transient response ground heat exchangers. Energy and Buildings 2008; 40: 1816-1824.

[117] Bandyopadhyay G, Kulkarni M, Mann M. A new approach to modeling ground heat exchangers in the initial phase of heat-flux build up. ASHRAE Transactions 2008; 2: 428-439.

[118] Lamarche L, Beauchamp B. New solutions for the short-time analysis of geothermal vertical boreholes. International Journal of Heat and Mass transfer 2007; 50:1408-1419.

[119] Claesson J, Javed S. An analytical method to calculate borehole fluid temperatures for time-scales from minutes to decades. ASHRAE Transactions 2011; 2: 279-288.

[120] Javed S, Claesson J. New analytical and numerical solutions for the short-term analysis of vertical ground heat exchangers. ASHRAE Transactions $2011 ; 117$ (1): 3-12.

[121] Shirazi AS, Bernier M. Thermal capacity effect in borehole ground heat exchangers. Energy and Buildings 2013; 67: 35264.

[122] Cui Y, Zhu J. 3D transient heat transfer numerical analysis of multiple energy piles. Energy and Buildings 2017; 134: 129_ 142.

[123] Remund CP. Borehole thermal resistance: laboratory and field studies. ASHRAE Transactions 1999; 105 (1): $439-445$.

[124] Wetter M, Huber A. TRNSYS TYPE 451 - Vertical borehole heat exchanger- EWS model- Model description and implementing into TRNSYS. Zürich//Luzern, Switzerland: Huber Energietechnik AG 1997. 
[125] Zarrella A, Scarpa M, Carli MD. Short time step analysis of vertical ground-coupled heat exchangers: The approach of CaRM. Renewable Energy 2011; 36: 2357-2367.

[126] Zarrella A, Carli MD. Heat transfer analysis of short helical borehole heat exchangers. Applied Energy 2013; 102 (2): $1477-1491$.

[127] Zarrella A, Capozza A, Carli MD. Analysis of short helical and double U-tube borehole heat exchangers: A simulationbased comparison. Applied Energy 2013; 112: 358-370.

[128] Zarrella A, Scarpa M, Carli MD. Short time-step performances of coaxial and double U-tube borehole heat exchangers: modeling and measurements. HVAC \& R Research 2011; 17 (6): 959-976.

[129] Bauer D, Heidemann W, Muller-Steinhagen H, Diersch HJG. Thermal resistance and capacity models for borehole heat exchangers. International Journal of Energy Research. 2011; 35 (4): 312-320.

[130] Bauer D, Heidemann W, Muller-Steinhagen H, Diersch, HJG. Modelling and simulation of groundwater influence on borehole thermal energy stores. In: Proceedings of Effstock, the $11^{\text {th }}$ International Conference on Thermal Energy Storage, Stockholm International Fairs, Stockholm, Sweden 2009.

[131] Pasquier P, Marcotte D. Short-term simulation of ground heat exchanger with an improved TRCM. Renewable Energy 2012; 46: 92-99.

[132] Biglarian H, Abbaspour M, Saidi MH. A numerical model for transient simulation of borehole heat exchangers. Renewable Energy 2017; 104: 224-237.

[133] Minaei A, Maerefat M. Thermal resistance capacity model for short-term borehole heat exchanger simulation with nonstiff ordinary differential equations. Geothermics 2017; 70: 260-270.

[134] Jaeger JC. Some problems involving line sources in conduction of heat. The London, Edinburgh and Dublin Philosophical Magazine and Journal of Science 1944; 35 (242): 169-179.

[135] Bejan A. Convection heat transfer. 4th ed. Hoboken: John Wiley \& Sons, Inc. 2013.

[136] Eskilson P. Superposition borehole model manual for computer code. Department of Mathematical Physics, University of Lund, Lund, Sweden 1986.

[137] Paul ND. The effect of grout thermal conductivity on vertical geothermal heat exchanger design and performance. Mechanical Engineering Department, SouthDakota State University 1996.

[138] Sharqawy MH, Mokheimer EM, Habib MA, Badr HM, Said SA, AlShayea NA, Energy, exergy and uncertainty analyses of the thermal response test for a ground heat exchanger. Available at: < http://faculty.kfupm.edu.sa/CE/nshayea/Papers/ Thermal-J1.pdf> 2008 [Accessed 12.12.08]. 
[139] Bennet, Johan, Claesson, Johan, Hellström, Göran. Multipole method to compute the conductive heat flows to and between pipes in a composite cylinder. Department of Building Technology and Department of Mathematical Physics, Lund Institute of Technology 1987.

[140] Claesson J, Hellström G. Multipole method to calculate borehole thermal resistances in a borehole heat exchanger. HVAC \& R Research 2011; 17: 895-911.

[141] Ruiz-Calvo F, Rosa MD, Monzó P, Montagud C, Corberán J.M. Coupling short-term (B2G model) and long-term (gfunction) models for ground source heat exchanger simulation in TRNSYS. Application in a real installation. Applied Thermal Engineering 2016; 102: 720-732.

[142] Ruiz-Calvo F, Rosa MD, Acuña J, Corberán JM, Montagud C. Experimental validation of a short-term Borehole-to-Ground (B2G) dynamic model. Applied Energy 2015; 140: 210-223.

[143] Ruiz-Calvo F, Rosa MD, Monzó P, Montagud C, Corberán J.M. A novel TRNSYS type for short-term borehole heat exchanger simulation: B2G model. Energy Conversion and Management 2015; 100: 347-357.

[144] Kuzmic N, Law Y, Dworkin S. Numerical heat transfer comparison study of hybrid and non-hybrid ground source heat pump systems. Applied Energy 2016; 165: 919-929.

[145] Belzile P, Lamarche L, Rousse DR. Semi-analytical model for geothermal borefields with independent inlet conditions. Geothermics 2016; 60: 144-155.

[146] Lamarche L. Short-time analysis of vertical boreholes, new analytic solutions and choice of equivalent radius. International Journal of Heat and Mass Transfer 2015; 91: 800-807.

[147] Ozudogru TY, Olgun CG, Senol A. 3D numerical modeling of vertical geothermal heat exchangers. Geothermics 2014; 51: $312-324$.

[148] Choi JC, Park J, Lee SR. Numerical evaluation of the effects of groundwater flow on borehole heat exchanger arrays. Renewable Energy 2013; 52: 230-240.

[149] Li Z, Zheng M. Development of a numerical model for the simulation of vertical U-tube ground heat exchangers. Apply Thermal Engineering 2009; 29: 920-924.

[150] Rees SJ, He M. A three-dimensional numerical model of borehole heat exchanger heat transfer and fluid flow. Geothermics $2013 ; 46: 1-13$.

[151] Nabi M, Al-Khoury R. An efficient finite volume model for shallow geothermal systems. Part I: Model formulation. Computers \& Geosciences 2012; 49: 290-296.

[152] Nabi M, Al-Khoury R. An efficient finite volume model for shallow geothermal systems. Part II: Verification, validation and grid convergence. Computers \& Geosciences 2012; 49: 297-307. 
[153] Mottaghy D, Dijkshoorn L. Implementing an effective finite difference formulation for borehole heat exchangers into a heat and mass transport code. Renewable Energy 2012; 45: 59-71.

[154] Diersch HJG, Bauer D, Heidemann W, Ruhaak W, Schatzl P. Finite element modeling of borehole heat exchanger systems. Part 1. Fundamentals. Computers \& Geosciences 2011; 37: 1122-1135.

[155] Diersch HJG, Bauer D, Heidemann W, Ruhaak W, Schatzl P. Finite element modeling of borehole heat exchanger systems Part 2. Numerical simulation. Computers \& Geosciences 2011; 37: 1136-1147.

[156] Cui P, Yang H, Fang Z. Numerical analysis and experimental validation of heat transfer in ground heat exchangers in alternative operation modes. Energy and Buildings 2008; 40: 1060-1066.

[157] Wołoszyn J, Goła's A. Modelling of a borehole heat exchanger using a finite element with multiple degrees of freedom Geothermics 2013; 47: 13-26.

[158] Wołoszyn J, Goła’s A. Sensitivity analysis of efficiency thermal energy storage on selected rock mass and grout parameters using design of experiment method. Energy Conversion and Management 2014; 87: 1297-1304

[159] Wołoszyn J, Goła’s A. Experimental verification and programming development of a new MDF borehole heat exchanger numerical model. Geothermics 2016; 59: 67-76.

[160] Pasquier P, Marcotte D. Joint use of quasi-3D response model and spectral method to simulate borehole heat exchanger. Geothermics 2014; 51: 281-299.

[161] Qi D, Pu L, Li Y. Numerical investigation on thermal performance of ground heat exchangers using phase change materials as grout for ground source heat pump system. Applied Thermal Engineering 2016; 106: 1023-1032.

[162] Wei J, Wang L, Jia L, Cai W. A new method for calculation of short time-step g-functions of vertical ground heat exchangers. Applied Thermal Engineering 2016; 99: 776-783.

[163] Kuzmic N, Law YLE, Dworkin SB. Numerical heat transfer comparison study of hybrid and non-hybrid ground source heat pump systems. Applied Energy 2016; 165: 919-929.

[164] Lee CK. A modified three-dimensional numerical model for predicting the short-time-step performance of borehole ground heat exchangers. Renewable Energy 2016; 87: 618-627.

[165] BniLam N, Al-Khoury R. A spectral model for heat transfer with friction heat gain in geothermal borehole heat exchangers. Applied Mathematical Modelling 2016; 4: 7410-7421.

[166] Dehkordi SE, Schincariol RA, Reitsma S. Thermal performance of a tight borehole heat exchanger. Renewable Energy 2015; 83: 698-704.

[167] Minaei A, Maerefat M. A new analytical model for short-term borehole heat exchanger based on thermal resistance capacity model. Energy and Buildings 2017; 146: 233-242. 
[168] $\mathrm{Hu}$ J. An improved analytical model for vertical borehole ground heat exchanger with multiple-layer substrates and groundwater flow. Applied Energy 2017; 202: 537-549.

[169] Zhang W, Cui P, Liu J, Liu X. Study on heat transfer experiments and mathematical models of the energy pile of building. Energy and Buildings 2017; 152: 643-652.

[170] Bozis D, Papakostas K, Kyriakis N. On the evaluation of design parameters effects on the heat transfer efficiency of energy piles Energy and Buildings 2011; 43: 1020-1029.

[171] Li M, Lai ACK. New temperature response functions ( $\mathrm{G}$ functions) for pile and borehole ground heat exchangers based on composite-medium-line-source theory. Energy 2012; 38: 255-263.

[172] You S, Cheng X, Guo H, Yao Z. Experimental study on structural response of CFG energy piles. Applied Thermal Engineering 2016; 96: 640-651.

[173] Hepbasli A, Akdemir O. Energy and exergy analysis of a ground source (geothermal) heat pump system. Energy Conversions and Management 2004; 45: 737-753.

[174] Ozgener L, Hepbasli A, Dincer I. Energy and exergy analysis of Salihli district heating systems in Manisa, Turkey. International Journal of Energy Research 2005; 29: 393-408.

[175] Ozgener L, Hepbasli A, Dincer I. Exergoeconomic analysis of geothermal district heating systems: a case study. Apply Thermal Engineering 2007; 27: 1303-1310.

[176] Hu P, Zha J, Lei F, Zhu N, Wu T. A composite cylindrical model and its application in analysis of thermal response and performance for energy pile. Energy and Buildings 2014; 84: 324-332.

[177] Gao J, Zhang X, Liu J, Li K, Yang J. Numerical and experimental assessment of thermal performance of vertical energy piles: An application. Applied Energy 2008; 85: 901-910.

[178] Lalouin L, Nuth M, Vulliet L. Chapter 16: Experimental and numerical investigations of the behaviour of a heat exchanger pile. Ground Improvement Case Histories 2015; p. 515-535.

[179] Modaressi H, Laloui L, Aubry D. Numerical modelling of thermal consolidation. $2^{\text {nd }}$ European Speciality Conference on Numerical Methods in Geotechnical Engineering, Santander 1991; 1: 280-292.

[180] Bandos TV, Campos-Celador A, López-González LM, Sala-Lizarraga JM. Finite cylinder-source model for energy pile heat exchangers: Effect of buried depth and heat load cyclic variations. Applied Thermal Engineering 2016; 96: 130-136.

[181] Bandos TV, Campos-Celador A, Luis M, Lopez-Gonzalez LM, Sala-Lizarraga JM. Finite cylinder-source model for energy pile heat exchangers: Effects of thermal storage and vertical temperature variations. Energy 2014; 78: 639-648.

[182] Bandos TV, Montero A, Fernández E, Santander JLG, Isidro JM, Finite line-source model for borehole heat exchangers: effect of vertical temperature variations. Geothermics 2009; 38: 263-270. 
[183] Loveridge F, Powrie W. 2D thermal resistance of pile heat exchangers. Geothermics 2014; 50: 122-135.

[184] Zarrella A, Carli MD, Galgaro A. Thermal performance of two types of energy foundation pile: Helical pipe and triple Utube. Applied Thermal Engineering 2013; 61: 301-310.

[185] Atam E, Helsen L. Ground-coupled heat pumps: Part 1 - Literature review and research challenges in modelling and optimal control. Renewable and Sustainable Energy Reviews 2016; 54: 1653-1667.

[186] Atam E, Helsen L. Ground-coupled heat pumps: Part 2-Literature review and research challenges in optimal design. Renewable and Sustainable Energy Reviews 2016; 54: 1668-1684.

[187] Li M, Lai ACK. Review of analytical models for heat transfer by vertical ground heat exchangers (GHEs): A perspective of time and space scales. Applied Energy 2015; 151: 178-191.

[188] Soni SK, Pandey M, Bartaria VN. Ground coupled heat exchangers: A review and applications. Renewable and Sustainable Energy Reviews 2015; 47: 83-92.

[189] Spitler JD, Gehlin SEA. Thermal response testing for ground source heat pump systems — A historical review. Renewable and Sustainable Energy Reviews 2015; 50: 1125-1137.

[190] Luo J, Rohn J, Xiang W, Bertermann D, Blum P. A review of ground investigations for ground source heat pump (GSHP) systems. Energy and Buildings 2016; 117: 160-175.

[191] Suryatriyastuti ME, Mroueh H, Burlon S. Understanding the temperature-induced mechanical behaviour of energy pile foundations. Renewable and Sustainable Energy Reviews 2012; 16: 3344-3354.

[192] Faizal M, Bouazza A, Singh RM. Heat transfer enhancement of geothermal energy piles. Renewable and Sustainable Energy Reviews 2016; 57: 16-33. 